\title{
NETWORKED REFUGEES
}

Palestinian Reciprocity and
Remittances in the Digital Age

NADYA HAJJ
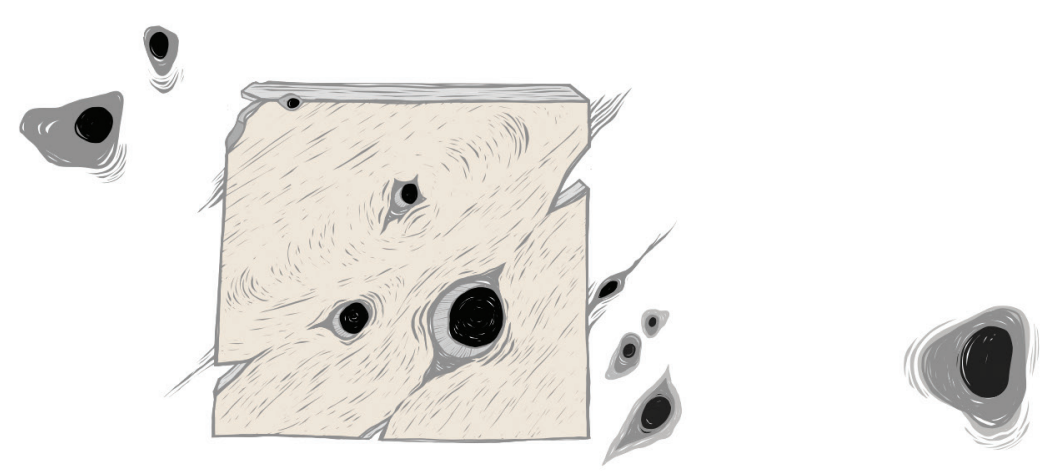

(9)

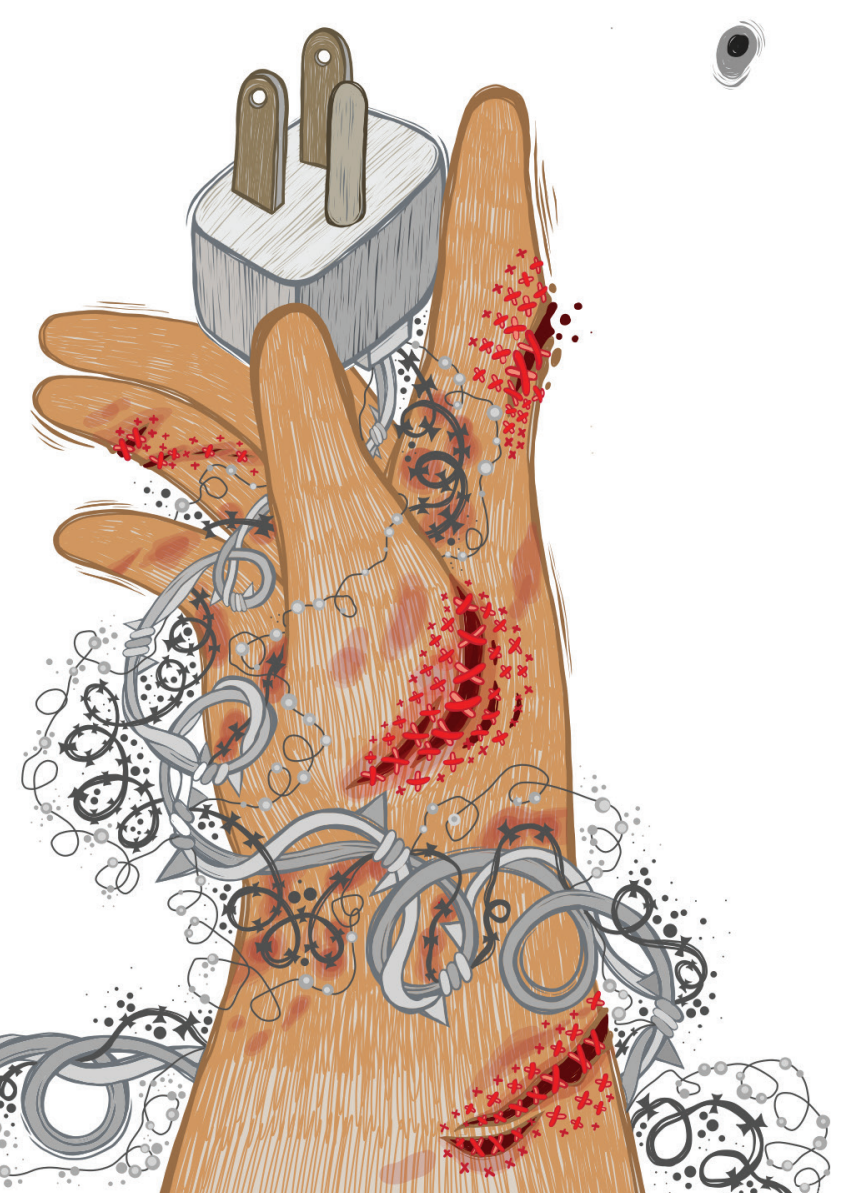


Luminos is the Open Access monograph publishing program from UC Press. Luminos provides a framework for preserving and reinvigorating monograph publishing for the future and increases the reach and visibility of important scholarly work. Titles published in the UC Press Luminos model are published with the same high standards for selection, peer review, production, and marketing as those in our traditional program. www.luminosoa.org 


\section{CRITICAL REFUGEE STUDIES}

Edited by the Critical Refugee Studies Collective

1. In Camps: Vietnamese Refugees, Asylum Seekers, and Repatriates, by Jana K. Lipman

2. Networked Refugees: Palestinian Reciprocity and Remittances in the Digital Age, by Nadya Hajj 
Networked Refugees 



\section{Networked Refugees}

Palestinian Reciprocity and Remittances in the Digital Age

Nadya Hajj

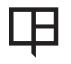

UNIVERSITY OF CALIFORNIA PRESS 
University of California Press

Oakland, California

(C) 2021 by Nadya Hajj

This work is licensed under a Creative Commons CC BY-SA 4.o license. To view a copy of the license, visit http://creativecommons.org/licenses.

Suggested citation: Hajj, N. Networked Refugees: Palestinian Reciprocity and Remittances in the Digital Age. Oakland: University of California Press, 2021. DOI: https://doi.org/10.1525/luminos.111

Library of Congress Cataloging-in-Publication Data

Names: Hajj, Nadya, author.

Title: Networked refugees : Palestinian reciprocity and remittances in the digital age / Nadya Hajj.

Other titles: Critical refugee studies ; 2.

Description: Oakland, California : University of California Press, [2021] |

Series: Critical refugee studies ; 2 | Includes bibliographical references and index.

Identifiers: LCCN 2021012046 (print) | LCCN 2021012047 (ebook) |

ISBN 9780520383241 (paperback) | ISBN 9780520383258 (epub)

Subjects: LCSH: Refugees, Palestinian Arab-Social networks-Lebanon. | Information technology-Social aspects-Lebanon. | Emigrant remittances-Lebanon. | Cooperation-Lebanon. | Refugees, Palestinian Arab-Lebanon-Economic conditions.

Classification: LCC HV640.5.P36 H354 2021 (print) | LCC HV640.5.P36 (ebook) | DDC 332/.04246089927405692-dc23

LC record available at https://lccn.loc.gov/2021012046

LC ebook record available at https://lccn.loc.gov/2021012047

$\begin{array}{llllllllll}30 & 29 & 28 & 27 & 26 & 25 & 24 & 23 & 22 & 21\end{array}$

$\begin{array}{llllllllll}10 & 9 & 8 & 7 & 6 & 5 & 4 & 3 & 2 & 1\end{array}$ 
It is always for my daughter, Leila 



\section{CONTENTS}

List of Illustrations ix

Giving Thanks xi

Preface xiii

1. Cooperation and Community Building in Catastrophe 1

2. Mapping Palestinian Ahl and Hamula Networks in Analog and Digital Spaces $\quad 26$

3. Reciprocity, Enforcement, and Economic Remittances 47

4. Social Remittances and the Disruption of Traditional Norms and $\begin{array}{ll}\text { Community Leaders } & 69\end{array}$

5. Reciprocal Activism in Digital Spaces 85

Research Appendix $\quad 95$

$\begin{array}{ll}\text { Notes } & 103\end{array}$

$\begin{array}{ll}\text { References } & 107\end{array}$

$\begin{array}{ll}\text { Index } & 119\end{array}$ 



\section{ILLUSTRATIONS}

\section{FIGURES}

1. Portrait of Mayssareh Saleh el-Haj, also known as Abu Ra'ed 40

2. Funerary rites collage of photographs of Abu Ra'ed 41

3. Posts per month on Samoie village Facebook page 44

4. Type of posts on Samoie village Facebook page 44

5. Interaction level on the Samoie village Facebook page by geographic location 45

6. Word cloud 62

\section{MAPS}

1. Village camp groupings in Nahr al-Bared 16

2. Geographic concentration of transnational Samoie village commenters 42 

I am thankful for the assistance of so many people in creating this book. It took a lot of my ahl (family) and hamula (village-tribe) to make it happen.

My ahl: My husband, Patrick, spent many evenings on our back porch talking with me about the project and insisting I keep at it. I am thankful for his unconditional love and support. While I was writing this book, our daughter, Leila, transitioned from a diaper-clad toddler to a "big girl" first-grader. The book was motivated by my desire to preserve Palestinian traditions for her, my sixthgeneration Palestinian girl. My Mom and Baba, Linda and Hatim Hajj, gave me ideas, read drafts, and encouraged me. My mother in-law, Elaine, read numerous book proposals and offered wisdom, prayers, and support. My extended Hajj family still living in the refugee camps in Lebanon gave me the support I needed to undertake the project. My Hajj family in Houston generously welcomed me into their homes and let me ask lots of questions. I can never repay the debt of gratitude I owe to you all. I hope to serve you with humility and dignity until the end of my days. Thank you.

My hamula: The same technologies that make it possible to build community among new generations of the Palestinian diaspora also facilitated the completion of this book. I used email, WhatsApp, and FaceTime to communicate with my research team and to access and collect data. Tracy Yandle helped field my earliest research questions and pointed me in the right theoretical direction. She has been a mentor since my first days in graduate school at Emory University. She was my first coauthor and a true role model for how a woman can have a family and thrive as a tenured professor while maintaining some semblance of sanity. Over lunch conversations and office chats, Peggy Levitt encouraged me to keep in mind 
the big picture. I am so fortunate to have a colleague and mentor like her just two floors up from my office at Wellesley College. Thank you.

Naomi Schneider and Summer Farah at the University of California Press were amazing editors and made me feel my voice mattered. Yến Lê Espiritu provided wisdom, encouragement, and guidance. The exceptionally talented Sara Qaed created the most beautiful art for my book. Thank you for putting my words into art. The Critical Refugee Studies Collective and Atalia Omer, Loren Lybarger, and Ora Szekely provided honest and constructive feedback as reviewers of the manuscript. I am thankful for comments from the Northeast Middle East Political Science Working Group on an early draft. They all made this book much better than it would have been otherwise. Of course, if there are any errors or omissions, they are most certainly my own.

I am grateful for the generous funding of the Knapp Social Science Research Fellowship and the Freedom Project Fellowship at Wellesley College.

I am thankful for the surveys conducted and data collected by Dr. Dina al-Haj, Omar el-Haj, Mohamed Aboujeamu, and Raghad al Hajj. Their dedication, Arabic language skills, and networks helped improve the reach and scope of my interviews with the Palestinian refugee community in Nahr al-Bared and the broader diaspora.

During the writing of this book, I never felt like a stranger when Virginia and Duane at the Framingham Chick-fil-A offered me an iced coffee and warm breakfast. Thank you for your kindness and smiles while I worked quietly at the back table for many years.

At Wellesley College, the students have been a wonderful asset to my project. Anne Schwartz wrote the computer code for analyzing data, brushed up on Arabic language skills, scraped the Facebook data, and generated maps and datasets that I could analyze to establish the transnational diaspora networks. Their initial help laid the groundwork for the efforts of my other fantastic research assistants, Rachel Kisken and Pris Nasrat. Janjan Sun helped expand my understanding of online transnational village linkages and always threw in a meme to keep me cool and make me laugh. Also at Wellesley, Withney Barthelemy helped me sift through mountains of journal articles and newspaper stories to generate a comparative idea of community-building practices. I am forever indebted to my friend and former student, Arielle Mitropoulos, and her mother, Nayla Sahyoun, for introducing me to and helping me to interview Dr. Anthony Sahyoun, Arielle's grandfather. Karim Sahyoun, Dr. Sahyoun's son, read an early draft and offered encouragement. Dr. Sahyoun was a Palestinian surgeon from Haifa who provided me with a most comprehensive firsthand account of medical practices, refugee landscapes, communal traditions, and the general social condition of Palestinians during the British mandate and the post-Nakba era. Not only did he devote decades to improving the health of Palestinian refugees, but he was a true gentleman who generously shared his time and invaluable memories with me. His is a legacy worth honoring. 
This study of reciprocity and remittances among networked refugees has unfolded in the worst of times for Palestinian refugee communities. I began making research visits to refugee camps across Lebanon, Jordan, and Syria in the summer of 2004. Since then, the structural conditions and communal psyche in the refugee camps have gone from very bad to catastrophic. It is hard to find the words to describe what it is like for successive generations to live in a refugee camp with few prospects for a better future. The thesaurus presents words like fatal, ruinous, tragic, and cataclysmic; and all those descriptors are accurate. Refugees face significant challenges in accessing clean water and food, finding safe housing, and even burying their dead. In one interview, a Palestinian refugee described a fear worse than death:

It's not the dying part that has worried me because, honestly, it will bring me peace to die and not live in this terrible place on Earth. But if I died, how would my family bury me? There is no place to bury, and families are left in very tough spots. I shudder to think of my wife and young children having to deal with the process. There would be no sanctuary for me, even in death. I don't even have a place to call home when my body dies. I know my soul will go to Paradise because I have been a good person, a good Muslim, you know? But, but ... where will my family place my bones? Where is our home?(I-96L) ${ }^{1}$

Though the Geneva Convention specifies the rights of refugees and the responsibilities of the global community to help them, the international community is increasingly reneging on those commitments. Host states in Europe, North America, and the Middle East routinely deny refugees and migrants the ability to bury bodies on their soil. Moreover, the continued Israeli occupation and 
violence in the Occupied Territories makes it impossible for Palestinians to assert the right of return to their homeland. There exists a vast chasm and legal gray area regarding the rights of refugees. Like the rest of the 68.5 million refugees suffering around the globe, Palestinians bear a significant burden of our casual disregard for the humanity of others, a state I refer to as brokenness.

I am humbled by the brokenness I have witnessed in refugee camps. I often feel overwhelmed by the conversations I have with refugees and by the reports I read of their suffering. There are times when hopelessness pervades my own outlook and writing. This is compounded by the fact that I am myself a Palestinian refugee. My father, Dr. Hatim Hajj, fled the village of Samoie in 1948 and grew up in Nahr al-Bared. He was the "lucky one" who received a scholarship that gave him access to educational opportunities beyond the confines of camp life. He went on to earn a master's degree and doctorate at universities in America. He continues, even into his late seventies, to send more than 10 percent of his income to his family (ahl) and village (hamula) in the camp. He has funded hundreds of college degrees and small business startups, and paid the medical bills and burial costs for countless people, some of whom are only distant relatives.

I had several conversations with Dr. Anthony Sahyoun, a retired Palestinian surgeon who lived in Wellesley, Massachusetts, before his passing in 2019. Dr. Sahyoun came from a prominent Christian family in Haifa, Palestine. Born in 1922, he grew up in Haifa during the British mandate and trained as a medical surgeon in Britain. At the time of the Nakba-the 1948 "Catastrophic War" that prompted the Palestinian refugee situation-he served Palestinians as a doctor in the Red Cross, and he later headed the first hospital serving Palestinians with the United Nations Relief and Works Agency for Palestine Refugees in the Near East (UNRWA). He recalled:

My father was a vice mayor in Haifa, sharing the role with Jewish and Muslim vice mayors. In 1948, when the war began, my father fled with the rest of the family and moved to Egypt. At that same time in 1948, I was sitting at my college flat in London and heard on the wireless radio an advertisement from the Red Cross looking for surgeons to work in Palestine and the Levant region. I agreed to sign on to the Red Cross. It was also at this time that I gained British citizenship. In 1949, I became the lieutenant colonel Red Cross chief of surgery in Jordan. I worked at the Salt Hospital, which served several Palestinian refugee camps. I had to organize the entire camp medical system: the clinics, the nurses, and an ambulance route. This was an enormous undertaking because I created the entire system on my own. I was young and had boundless energy. . . . I didn’t move away until 1958. By that time, I needed a change from the relentless pace.

He eventually moved to Boston, where he became associate professor of surgery at Harvard Medical School, chief of emergency medicine at the Faulkner Hospital, and associate chief of transplant surgery at the New England Deaconess Hospital. He never forgot the Palestinian community he left behind in the refugee 
camps, and he expended his time, social capital, and income to set up an exchange program that enabled Palestinian medical doctors to undertake medical residency and training in Boston. He also funded trips for Palestinian refugee children to receive life-saving medical operations at American hospitals. Even into his late nineties, his generosity helped generations of Palestinian doctors better serve their own suffering people.

Sadly, in the past two years, almost the entire generation of Palestinians who remembered the Nakba and the early years of life in the refugee camps-including Dr. Sahyoun and five of my father's six siblings-has passed. I wonder whether successive generations of the Palestinian diaspora will serve members of their community still living in the camps in the same way that earlier generations did.

How can refugee communities overcome the brokenness of the world? In Just Mercy, Bryan Stevenson contemplates the challenges of the American judicial system and the harsh punishments that offer no hope for redemption to some of those who suffer most in our society. In pondering how we might reclaim our regard for humanity, and heal the fracturing of our communities, he observes, "There is no wholeness outside of our reciprocal humanity" (Stevenson 2014, 290). Reciprocity, or the exchange of privileges, favors, and services with other members of a social network, as embodied in the actions of my father and Dr. Sahyoun, is the key to rebuilding refugee communities amid global apathy and repression (Mauss 1954).

But how can dispersed, oppressed, and disadvantaged communities engage in acts of reciprocity? This book endeavors to understand how refugees living in the camps use digital platforms like Facebook to inspire reciprocity among transnational networks of Palestinians and improve their overall well-being. It offers a glimmer of hope by showing how the community is rebuilding and reimagining itself, albeit slowly and imperfectly, by melding modern technologies with Palestinian norms and values of loyalty, honor, steadfastness, and shame, collectively known as 'adat wa taqlid, to inspire new generations of Palestinians to assist others who are suffering and offer money and services to those still living in the camps. The book aims to show how networks of refugees inspire reciprocity and the multidirectional flow of economic and social remittances in the digital age. 



\section{Cooperation and Community Building in Catastrophe}

The hegira, or perilous journey, of refugees causes them to lose both their homes and the protections afforded to them by a state. Though the Geneva Convention specifies their rights, there is no accessible, state-bounded framework by which refugees can demand protection or expect the enforcement of these rights (Hajj 2014, 2016; Jacobsen 2005). This "protection gap," the chasm between promised legal protections and actual treatment, has widened in recent years because of the increasing demands placed on humanitarian services, with more than 68.5 million refugees displaced worldwide, and host countries' abrogation of their legal obligations to refugee communities (Aleinikoff and Zamore 2019).

The protection gap is especially evident with regard to Palestinian refugees because the ongoing violent conflict with Israel prevents refugee repatriation, even though United Nations General Assembly Resolution 194 (III) of December 1948 states their right of return. While Israel contends that Palestinian refugees are the problem of neighboring Arab states, many Arab host states, like Lebanon, refuse integration (tawtin) of Palestinians into economic and social structures, even after more than seventy years (Masalha 2003; Sayigh 1995a). Denial of the right of return and meager host-country support are further compounded by dwindling aid for the United Nations Relief and Works Agency for Palestine Refugees in the Near East (UNRWA), the only UN agency responsible for providing welfare, goods, and services to Palestinian refugees. On August 30, 2018, President Donald Trump announced the withdrawal of US funding for UNRWA. On April 7, 2021, President Joseph Biden reinstated this funding, but the budget crisis of the last several years continues to limit access to vital goods and services.

The disorientation of the refugee condition was poignantly described to me by one Palestinian refugee in Lebanon: "I do not know what is up and what is down. I do not know the words to ask for help and the person to ask for it. Do I even 
count anymore as a person?" (I-8L). Indeed, there is a pervasive sense of despair among Palestinian refugees that the world has left them behind. The Palestinian American poet and activist Suheir Hammad (2004) describes the Palestinian refugee condition: "Every day you die, and the world watches in silence. As if your death was nothing, as if you were a stone falling in the earth, water falling over water." The despair was echoed in a recurrent phrase I heard in conversations with refugees in camps across Lebanon. Refugees lamented, "Min 'eeash bedoun amal" (We live without hope).

Community "scouts" who traveled abroad to find economic opportunity and send money or remittances "home" to the camps mitigated abject poverty and hopelessness in the initial years after the 1948 Nakba (Jacobsen 2005; Levitt 2001; Masalha 2003; Schiff 1993). These scouts formed part of the Palestinian diaspora. Indeed, though much research on Palestinians today is centered on the West Bank, the Gaza Strip, and Jerusalem, the Palestinian diaspora is vast and still plays an essential role in the survival of the Palestinian community (Hammer 2005, 11). I adopt the term diaspora because it attends to the liminal transnational space that Palestinian refugees occupy. As Thea Abu el-Haj notes in Unsettled Belonging, the term diaspora, unlike the category of immigrant, attends to the processes of globalization and migration that lead refugees to forge a sense of transnational belonging and connection (Abu el-Haj 2015, 29).

As members of the diaspora have worked hard to survive and adapt in new host states, their remittances have helped refugees in the camps build better homes, obtain food, send children to school, and access specialized medical care that is not provided by host states or aid agencies (Hajj 2016). Remittances often exceed the amount of official development assistance to refugees and marginalized communities. In 1995, migrants around the world sent more than US $\$ 70$ billion back to families. Remittances significantly improve health, education, and welfare services in the imperfect market conditions that refugees face (Taylor 1999, 63, 81). In addition, they mitigate conflict and displacement because "some portion of the remittances also goes to religious organizations and hometown associations that sustain the community in crisis" (Koser and Van Hear 2003, 60).

Remittances have fueled economic growth and hope for new generations of Palestinians in the camps. One elderly refugee in the diaspora said: "There is no one else to help us. It is terribly unsettling to realize we are on our own despite all the bad things others have done to us, especially knowing that they legally owe us better. I do not operate in a world of perfect solutions, where I magically create a new state for us. I operate in a real-world place of sending as much money as I can, when I can, to help my people survive for a better future" (I-116L).

But remittances may decrease with time and distance, a phenomenon known as remittance decay (Jacobsen 2005). As global conflicts persist and the older generations of scouts dies, the diaspora's bonds of loyalty to the camp communities weaken while the protection gap widens. How do refugees today access the goods 
and services they desperately need? Specifically, how do Palestinian refugees continue to motivate reciprocity, a cooperative interaction marked by the exchange of favors and privileges (Lawson and Greene 2014; Mauss 1954; Stack 1974), and, in turn, spark remittance flows from the transnational diaspora?

Even in lab-controlled conditions, cooperative behavior can be a challenge for people (Axelrod 1984; Axelrod and Hamilton 1981; Fehr and Gächter 2002; Fehr and Henrich 2003). Kin-based groups with repeated interactions are more likely to engage in reciprocity, but the time and distance separating refugee family networks create challenges. Though certainly not a perfect solution to the challenges refugee face, information communication technologies (ICTs) may offer a virtual space where refugees can reconstitute their community and memories. Furthermore, this space might serve to generate real-world material benefits in the form of economic remittances.

Studies of the role of ICTs in refugee spaces have generally been limited to exploring how aid agencies use them to map assets and distribute resources (e.g., Maitland and $\mathrm{Xu}$ 2015). These studies consider ICTs as a potential "digital lifeline" to improve the flow of international aid (Maitland 2018). Few studies have examined how refugees, without the intervention of international aid agencies, develop their own transnational digital networks and access resources that help them endure and even thrive (Oirzabal 2010).

In his novel Exit West, Mohsin Hamid poignantly describes forced migrations and the refugee condition. He describes the relationship of two refugee protagonists to their cell phones: "Nadia and Saeed were, back then, always in possession of their phones. In their phones were antennas, and these antennas sniffed out an invisible world, as if by magic, a world that was all around them, and also nowhere, transporting them to places distant and near, and to places that had never been and would never be" (Hamid 2017, 39). In his portrayal, refugees use smartphones to transcend geographic borders and tap into a global network to build a community and access needed resources.

In the real world, however, researchers are divided over the question of whether Internet-based platforms generate tangible benefits for users. Technology pessimists view ICTs as a force causing individuals to turn inward, to deny their embeddedness in the social fabric, and to become apathetic (Simanowski 2018). Technology optimists consider ICTs to be a vehicle for sociopolitical change (LaBelle 2018). They view ICTs as nonstate market mechanisms that empower individuals to connect with one another, share information, and engage in collective action (Lynch 2011; Shirky 2011).

Since the beginning of the Industrial Revolution, philosophers have observed that although technology enables us to communicate with increasing speedthrough, successively, the telegraph, the telephone, radio, television, and the internet-it does not bring us nearer to one another, in the sense of feeling that we are deeply connected to others even when separated by vast geographic distances. 
Nearness entails the realization that our existence is dependent on the support of others. Technology enables us to overcome the barriers of time and distance, but, as the Nobel laureate Emily Greene Balch observed in 1948, "Technology is a tool, not a virtue. It may be used for good or bad ends, and bringing men closer does not make them love one another unless they prove lovable. Multiplying contacts can mean multiplying points of friction" (Balch 1948). ICTs may allow refugee communities to create transnational networks, but these connections do not guarantee and in fact may impede nearness and real-world exchanges of support.

To create nearness and all the potential benefits it entails for refugees, individuals must relate more to a communal truth-that people living far apart from one another are deeply connected and interdependent-than to the technology itself. For ICTs to inspire reciprocity and help the Palestinian community survive catastrophic conditions, refugees must use them to evoke culturally and historically specific connections with members of the diaspora. The enforcement of norms or shared understandings of expected behavior in familiar group settings is often identified as a key motivator for cooperation and reciprocity (Axelrod 1984; Boyd et al. 2003; Fehr and Gächter 2002; West, Griffin, and Gardener 2006).

Examining the digital behavior of Palestinians living in camps in Lebanon and the diaspora generates new data on the role of reciprocity and ICTs in refugee community building. Through refugee camp interviews, surveys with members of the diaspora, and Internet data scraping, or collection of data, using Selenium WebDriver and Google Maps API, I have found that Palestinian refugees are adept at strategically melding forms of social organization and norms of communal behavior with new technologies to rebuild their community amid the contemporary catastrophe. Specifically, the representation of precrisis family and village networks in digital spaces allows Palestinians living in refugee camps to connect with the transnational diaspora in culturally and historically familiar ways. ICT users strategically deploy behaviors that are malleable and fluid versions of traditional Palestinian communal behavior.

This research disentangles the multiple levels of connection that make up the transnational Palestinian identity. In the camps, people remain connected to Palestine through subnational, village, and family identities. These in turn enable those who have left the camp, who live in a kind of double diaspora-separated first from Palestine and second from the camp - to remain connected to the camp, and, through that connection, to Palestine itself. Broadcasting the Palestinian norms and values of loyalty, honor, steadfastness, and shame, collectively known as the 'adat wa taqlid, via digital videos, images, and chat rooms motivates continued remittance flows to those in the camps. Diaspora remittances provide valuable public goods for the camp community and fill the protection gap left by host states, elite political parties, and international aid agencies. The reciprocal networks of remittance flows speak to the power of the ahl and hamula identities, but also to the power of a Palestinian refugee identity that exists within a larger Palestinian 
national identity. These digital spaces of subnational connection also empower new community members and new conversations that may disrupt the very social dynamics and norms that initially anchored the community. Nevertheless, Palestinian refugees' strategic use of ICTs to generate reciprocity and remittances offers a window into the resilience and reimagined identity of a marginalized community enduring a broken world.

\section{THE PALESTINIAN REFUGEE CAMPS IN LEBANON}

Palestinian refugee camps in Lebanon are an unlikely site for the emergence of a vibrant transnational community, capable of providing its own public goods and services, because there are numerous atomizing forces at work. The protracted conflict, the exposure to violence, and the host country's refusal to integrate Palestinians into its economic structures have pushed many young Palestinians to seek economic opportunity abroad (Hajj 2014, 2016).

For the Palestinian refugee community, both in the camps and in the diaspora, Israeli occupation makes the return to their ancestral lands practically impossible. This situation was born of violence and instability when the state of Israel was created (Schiff 1993). The scale of this catastrophe cannot be overestimated. In 1948, 720,000 to 750,000 Palestinians were forced into exile-a majority of the Arab population at the time (Brand 1988; Schiff 1993). Dispossession is not merely a state of mind for refugees: it is codified in the legal statutes of host states and Israeli occupation. The purpose of Israeli occupation is to accumulate territory, deny the existence of an indigenous community, and cut off the possibility for commonality, connection, and collective activism. Patrick Wolfe maintains the occupation is "not a singular event but an on-going organizing principle" that "strives for the dissolution of native societies" $(2006,388)$. Through a variety of legal codes, informal policies, and Israeli lobbying, Palestinians are treated as mythical. Masalha (2003) argues that Israel's denial of the right of return has created a permanent situation of "warehoused" Palestinian refugees who are kept in a marginalized, disenfranchised status while Israel reinforces its own power and domination over Palestinian territories through legal and policy strategies. The impossibility of returning home, the erasure of Palestinian identity, and denial of Palestinian claims to territory forcefully atomize society (Masalha 2003; Wolfe 2006, 388). ${ }^{1}$

Aside from Israeli policies, Palestinian refugees in Lebanon have had a frontrow seat during many of the violent conflicts in the Middle East region. Even after settlement in refugee camps outside the Occupied Territories (OT), they witnessed and experienced massacres, like the ones in Sabra and Shatila in 1982 during the decades-long Lebanese civil war (Sayigh 1986). Since the end of the civil war, Palestinian refugee camps have become pawns in regional elite politics.

In After the Last Sky, his 1986 collaborative venture with Jean Mohr, Edward Said, the famed Palestinian scholar, reflects on the dispossession and fragmentation 
of Palestinian society. The first part of the work, called "States," is a passionate and moving meditation on displacement, landlessness, exile, and identity:

Do we exist? What proof do we have? The further we get from the Palestine of our past, the more precarious our status, the more disrupted our being, the more intermittent our presence. When did we become a people? When did we stop being one? Or are we in the process of becoming one? What do those big questions have to do with our intimate relationships with each other and with others? We frequently end our letters with the motto "Palestinian love" or "Palestinian kisses." Are there really such things as Palestinian intimacy and embraces, or are they simply intimacy and embraces-experiences common to everyone, neither politically significant nor particular to a nation or a people? (Said 1986, 34)

Indeed, the living conditions for Palestinians in Israel and Lebanon work against any sense of "Palestinian intimacy and embraces." The Nahr al-Bared refugee camp offers a microcosm in which to examine the processes of atomization and community efforts to build transnational networks and procure diaspora remittances. Nahr al-Bared was built in 1951 roughly sixteen kilometers from the port of Tripoli in Lebanon, on the Mediterranean Sea.

On May 15, 2007, Nahr al-Bared was destroyed during a military conflict between the Lebanese army and Fatah al-Islam, an extremist group with murky, nonPalestinian origins that attacked Lebanese forces using Nahr al-Bared as a base of operations (Butters 2008; Hajj 2016). Roughly twenty-seven thousand of the thirty thousand people then resident in the camp were forced to relocate. UNRWA, international donors, and the Lebanese government have slowly rebuilt the camp. The reconstruction project involves 4,876 residential units, 1,150 shops, the UNRWA compound, and the camp's entire infrastructure (Hajj 2016, 26). As of 2020, 54\% of camp residents had returned to Nahr al-Bared (De Stone and Suber 2019).

Palestinian refugees' exposure to violence is compounded by the Lebanese refusal to integrate them into Lebanese society (Sayigh 1995b). In Lebanon, the state leadership actively works against Palestinian community building. In an international interview in 1999, Prime Minister Rafic Hairiri said, "Lebanon will never, ever integrate Palestinians. They will not receive civic, or economic rights, or even work permits. Integration would take the Palestinians off the shoulders of the international agency which has supported them since 1948" (Cooley 1999). The economic isolation of Palestinian refugees has been codified through work restrictions and impositions against property ownership outside the refugee camps. Palestinian political parties like the Palestinian Liberation Organization (PLO) also oppose tawtin.

Palestinians in Lebanon, unlike those living in Jordan, were not issued passports. Obtaining alternative travel documents is often difficult. Lebanon's 1964 and 1995 laws outline the rights and responsibilities of foreigners to live and work in Lebanon, but Palestinians are considered a special case. A 2002 law forbade Palestinians from owning land or buying property in Lebanon (Christoff 2004). 
Even though these laws have been amended, the majority of Palestinians lack access to legal employment in Lebanon (Chaaban et al. 2016). These conditions have encouraged young Palestinians to leave the camps to seek economic opportunities. In a recent survey, a college-educated twenty-three-year-old Palestinian engineer from Nahr al-Bared wrote:

There is nothing for me here in Nahr al-Bared camp. I could go to Beirut like my brother and work as an illegal laborer in a restaurant. Maybe I become a waiter and make a pittance ... but then I am always fearful of getting ripped off by my boss and working like a dog. I would barely be able to make enough to feed myself. I can't save enough to afford my own place and get married. It is not a real life worth living. So I came up with a different plan. I borrowed money from my [second] cousin, who digitally sent me money to buy a passage to Turkey. From Turkey I will try to make it to Croatia or even Germany. I am a trained engineer with skills, and I have drive. I want to make it and use my God-given talents. I want a good life too. Why shouldn't I want a good life just because I am Palestinian? I am willing to risk my life to live with some dignity. (S-16)

However, leaving the camps for diaspora scouts means leaving the family and village networks that remain essential for individual and community survival (Levitt 2001; Hajj 2016). Moreover, as the flow of remittances dwindles over time, those left behind in the camps no longer benefit from the opportunities discovered by the diaspora scouts (Jacobsen 2005, Levitt 2001).

Certain community strategies can overcome the fracturing of ties. The Palestinian diaspora, especially the young, is shaped, according to one observer, by the "crucible of globalization with its attendant mass migration, dislocation culture, and technological advances that allow people to remain connected to multiple places" (Abu el-Haj 2015, 43). This process is less about Palestinians figuring out how to negotiate between cultures than about how they have developed discourses and practices of belonging across transnational social fields.

Palestinians, like members of many Arab communities, most certainly enculturate with societies they have migrated to, but they often maintain connections across transnational social fields too (Gualtieri 2019; Lybarger 2020). In Arab Routes (2019), Sarah Gualtieri examines the rich presence of Syrians in California. The cover of her book shows a quintessential California muscle-man beach scene with a Syrian ice-cream store "hidden" in plain sight. Arabs are a normal part of the American landscape. ${ }^{3}$ Other scholars have identified myriad ways in which transnational migrants can engender sustainable forms of diasporic cultural production and creatively navigate the complexity of living in transnational social fields (Abu el-Haj 2015, 30; Appadurai 1996; Basch, Glick Schiller, and Szanton Blanc 1999; Fouron and Glick Schiller 2002; Levitt and Glick Schiller 2004; Levitt and Waters 2002; Ong 1999).

Some communities manage to overcome remittance decay through strategies like altruism, social pressures, and diaspora scouts (Levitt 2001). Researchers have 
observed that "the [home] community notices who sends and who does not, and remittances are a way to exhibit connections, prove that relatives are cared for, and maintain contact with the country of origin" (Koser and Van Hear 2003, 62). ICTs may serve as one means of overcoming geographic limitations, connecting refugees with their diaspora community, and inspiring economic remittances. Of course, fulfilling economic aspirations will not serve as a cure-all for the challenges faced by Palestinian refugees, but the continued flow of remittances to the camps is a critical aspect of refugee community building.

\section{ICTS AND COMMUNITY BUILDING}

Long before the internet, scholars argued that "new" media lowered information costs, empowered everyday citizens, and strengthened the public sphere. Jürgen Habermas (1962) argued that the printing press helped democratize Europe by providing space for discussion and agreement among engaged citizens even before states had consolidated democracies. However, the emergence of new media alone does not spur individuals to action. Katz and Lazarsfeld (1955) argue that information must be repeatedly shared by engaged citizens and then echoed by other people to generate discussion. Widening the public sphere and motivating action requires the consumption and (re)production of information through the use of new media. The internet moves beyond earlier forms of media in that it enables individuals to produce as well as consume information in a decentralized manner, using non-state-run technologies like smartphones. Yochi Benkler refers to this new form of the information economy as a "networked information economy" $(2006,3)$. The existing scholarly record provides mixed perspectives on the potential of ICTs in building communities.

On the one hand, technology pessimists doubt that the use of ICTs will create empathetic individuals capable of consuming accurate information and translating that knowledge into activism. In recent years, a wave of scholarship has disputed the notion that ICTs are effective in countering the unequal distribution of power. In The Death Algorithm and Other Digital Dilemmas (2018), Roberto Simanowski (2018) wonders if humanity is on the brink of relying on technology to solve socioeconomic and political ills. He reviews the algorithms programmed into driverless cars that remove elements of human agency and deliberation (including algorithms that make choices about potentially fatal collisions). $\mathrm{He}$ provocatively describes smartphone zombies (or "smombies") who remove themselves from the physical world to the parallel universe of social media networks and thereby lose their awareness and agency for finding solutions to the real problems our world is facing. According to these theories, refugee and diaspora members immersed in digital technologies would not be capable of making personal connections that could overcome the brokenness in which they are embedded.

Moreover, technology pessimists fear that even if individuals are interested in more than just self-serving "likes" on social media platforms, the information they 
consume is rarely truthful, because people succumb to "fake news" online-false stories and rumors that impede social organization and collective action. This problem is compounded by the fact that state officials often produce their own fake stories or monitor and control the digital space. In her study of Russia's "winter of discontent," Sarah Oates argues that "on-line communication is not a 'magic bullet' that can empower citizens and change regimes" (Oates 2013, 2-3). Technology pessimists further assert that even if individuals are engaged and have access to accurate information, this rarely translates to real-world activism. In effect, they become "slacktivists," or individuals who express interest in activism online but do not behave accordingly. In a networked information economy filled with smombies, fake news, and slacktivists, the prospects for community building through ICTs seems dim.

By contrast, technology optimists maintain that the internet could serve as a solution for the world's ills. Mohsin Hamid's optimistic, albeit fiction-based, view of the internet (2017) is echoed in Brandon LaBelle's Sonic Agency (2018). LaBelle's radical scholarship assesses the connection between sharing sounds (not just visual images) in networked digital spaces and the capacity to (re)generate communities and motivate resistance to the existing world order. In this view, by lowering the cost of producing and consuming information, ICTs promote (although they do not guarantee) transformative social and political behavior. Some digital platforms, like Facebook and Twitter, enable public displays of social engagement through the sharing of written and audiovisual material. Others, like WhatsApp and Viber, offer opportunity for "private" conversations with specific individuals or family and village groups. ${ }^{4}$ Optimists agree that social media platforms have the most dramatic effects in places where the public sphere is constrained by the government (Groshek 2012; Lynch 2011; Shirky 2011). This was especially evident during the Arab revolutions of 2010 and 2011, when ICTs played a key role in catalyzing social change (Hajj, McEwan, and Turkington 2017).

\section{REFUGEES AND ICTS}

Refugees, in contrast to citizens of states, face different challenges and possibilities in using ICTs for community building and development. Scholarship in refugee camps has assessed access to and use of ICTs. For example, Maitland and Xu (2015) focused on basic ICT usage demographics among Syrian refugees in the Zaatari refugee camp in Jordan. Za'atari is one of the world's largest camps, accommodating eighty thousand Syrian refugees. The researchers hypothesized that urban, camp-based, and resettled refugees might have distinct information needs and varying levels of access to mobile networks and the internet compared to citizens of in host states. They found that "the diversity of Internet access modes is reduced, with mobile becoming critical, as people are displaced" (Maitland and Xu $2015,2)$. Refugees were eager to use social media for a variety of reasons, including communication with loved ones, feeling connected, overcoming isolation, and 
having their stories told (Maitland and $\mathrm{Xu}$ 2015, 1). Social media such as Facebook and mapping technologies were seen as useful in coordinating travel to neighboring countries. Refugees primarily used WhatsApp, Google Voice, and Viber to communicate with people living in Jordan and Syria. Their three most popular information sources were Google, Facebook, and YouTube.

\section{AID AGENCY USE OF ICTS}

Scholars studying refugees and ICTs have extended their research to investigate how the UN and other international aid agencies might better deliver resources, assess asset distribution, and build community in refugee spaces. In Digital Lifeline (Maitland 2018), scholars consider how ICTs are pushing humanitarian aid agencies into a new world of "digital humanitarian brokerage," where technology serves to assist organizations in tracking patterns or flows of refugees' movements, identifying immediate needs, delivering resources, and facilitating resettlement.

For example, some scholars have considered the role of mapping technology in facilitating community building in refugee spaces. Mapping technology was first used by international humanitarian aid agencies during the early stages of disaster and crisis situations to make rapid, accurate, geocoded population counts and identify the most urgently needed supplies. Carleen Maitland and Ying Xu (2015) argue that a public participation geographic information system (PPGIS) can be used to engage a variety of camp stakeholders in making critical decisions that influence the living conditions and welfare of all camp residents. They found that PPGIS was a critical tool for community building in the Zaatari camp because it enabled camp managers and some refugees to access mapped data and coordinate long-term plans as the camp evolved from a temporary place to a more citylike space.

Despite the advantages of deploying ICTs to solve logistical problems in providing aid, they have limitations for refugee community building. One is that the use and management of digital technologies and maps are often restricted to camp leaders and aid officials, with limited opportunity for much of the community to participate. Often the most vulnerable and marginalized-those with the greatest need for resources and connectivity-are precisely those who are left out of these community-building projects (Maitland and $\mathrm{Xu} 2015$ ).

Second, while these applications of ICTs certainly support community wellbeing in refugee camps and improve organizational responses to crises, they have limited capacity to connect refugees to their transnational diasporic networks, which may represent an untapped resource. When ICTs connect refugees with their family members in the diaspora, pockets of opportunity that had previously been ignored or underutilized can be identified and harnessed.

Third, while aid agency funding for basic web connectivity in the camps, like free Wi-Fi hubs, is crucial, ICTs are more effective at generating a sense of nearness among refugees because they replicate existing community kinship networks 
and norms. Dana Moss (2016) finds that ICTs played a critical role in developing transnational connections between refugees in the Syrian diaspora. Moreover, Pedro Oirzabal's excellent analyses of Basque diaspora digital networks (2010, 2012a,b) show that ICTs may be crucial in allowing diaspora groups to maintain community identity and share information. Men, women, the young, and the old all access and communicate through the Basque association groups on Facebook (2012a). Similar uses of ICTs to establish transnational identity have been observed among Salvadoran families (Benitez 2012), Uighurs (NurMuhammad et al. 2016), Filipinos (McKay 2010), and Arabs in Germany (Rinnawi 2012). These studies, which evidence the vast community-based digital networks organically patterned on precrisis or "home" groupings, show that many refugee communities might already have digital networks in place, which can then be activated to maintain bonds and access financial resources. In summary, though aid agencies have instituted top-down programs and designed technologies to efficiently map refugee communities and distribute aid, they rarely harness existing family and village support networks and their wealth of resources to facilitate community building amid protection gaps.

\section{GENERATING RECIPROCITY}

Existing scholarship on ICTs and refugees does not contend with the central insight that technology is powerful only insofar as it creates nearness among people: that is, it creates an awareness that each individual's existence is bound up with that of others in the same web for survival and that they must take real action to preserve that interconnection (Stevenson 2014, 290). The digital space encourages real-world action and overcomes the ever-present issues of remittance decay and drift among refugees when it inspires cooperation in the form of reciprocity, or the exchange of privileges and favors. However, how reciprocity can occur in digital spaces among geographically fragmented refugee communities living in catastrophic protection gaps is fertile research territory.

Before considering the roots of reciprocity, it is important to establish clear definitions of relevant terms. At their core, terms like cooperation, altruism, collaboration, and reciprocity convey a general sense of care for others (Oliner and Oliner 1988). ${ }^{5}$ There is a spectrum of caring activity, ranging from small, everyday acts like holding a door open for another person to extraordinarily creative and self-sacrificial ones, like donating an organ to a stranger (Gruber 1997). Cooperation refers to a behavior that provides a benefit to another individual and, from the perspective of evolutionary biology, is selected for because it benefits the recipient. Altruism is a behavior that is costly to the actor and beneficial to the recipient; in evolutionary biology, the cost and benefit are defined on the basis of lifetime direct fitness, or the survival of the community through productive offspring (West, Griffin, and Gardener 2006). 
In this book I focus on reciprocity because it underscores the mutual nature of the relationship, sometimes imposing great cost, self-sacrifice, or inconvenience on those involved. Moreover, reciprocity is not an attribute evident in only the most generous among us. Even in contexts that would otherwise reward selfish behavior, reciprocity may emerge (Fehr, Fischbacher, and Gächter 2002). Reciprocity is the fundamental social interaction involving giving and receiving gifts, like goods and services, among both kin and communities kinlike in nature (Lawson and Greene 2014). An object given or traded represents "a possession, a pledge, a loan, a trust, a bank account-given on the condition that something will be returned, that the giver can draw on the account, and that the initiator of the trade gains prerogatives in taking what he or she needs from the receiver" (Stack 1974, 38). Marcel Mauss's classic interpretation of the gift exchange stresses the obligation inherent in gift giving, receiving, and repayment. Although giving a gift may appear to be voluntary, the offering is essentially obligatory and required. Mauss shares the story of Tamati Ranaipiri, a Māori, to illustrate how the spirit of gift giving works in some societies. Tamati Ranaipiri explains:

I shall tell you about hau. Hau is not the wind. Not at all. Suppose you have some particular object, taonga, and you give it to me; and you give it to me without a price. We do not bargain over it. Now I give this thing to a third person who after a time decides to give me something in repayment for it (ute), and he makes me a present of something (taonga). Now this taonga I received from you and which I passed on to him and the taonga which I receive on account of the taonga that came from you, I must return to you. It would not be right on my part to keep these taonga whether they were desirable or not. I must give them to you since they are the hau of the taonga which you gave me. If I were to keep this second taonga for myself I might become ill or even die. Such is the hau, the hau of the taonga, the hau of the forest. Enough on that subject. (Mauss 1954, 261).

This account reveals that the obligation associated with a gift is not inert but a living thing that strives to bring some equivalent to take its place. According to Mauss, one may feel a compulsion to rebalance the scales after an exchange, but it is more likely that sanctions are necessary for procuring repayment of a gift. The recipient of the gift can discharge debts by providing a good or service of comparable worth to the original gift; however, not all recipients can repay the givers. In these cases, recipients may balance the ledger by according the giver greater social status, esteem, or loyalty (Lawson and Greene 2014; Mauss 1954; Stack 1974).

There is a rich literature on reciprocal exchanges. Importantly, this literature is divided on the universal and proximate causes of reciprocity, and these causal mechanisms are often conflated. However, it is useful to differentiate the two because my project is decidedly focused on proximate causes of reciprocity. Studies that focus on universal arguments tend to consider the indirect and direct benefits of cooperation for the "fitness," or survival, productivity, and reproduction of a 
species. Social evolutionary biologists and neuroscientists conclude that we cooperate because it ensures the long-term survival of our species (Lawson and Greene 2014; West Griffin, and Gardener 2006). Proximate causes of cooperation consider how individuals spur reciprocal behavior. Humans are different from other species in that the proximate causes of reciprocity tend to involve schemes of incentives, rewards, and punishment that are attentive to specific local conditions (Crespi 2006; Fehr, Fischbacher, and Gächter 2002; Fehr and Fischbacher 2004; Fehr and Gächter 2002; Henrich et al. 2005; Mauss 1954; Stack 1974; Wedekind and Braithwaite 2002; West Griffin, and Gardener 2006).

From the extensive literature I have distilled several proximate causes of reciprocity. First, individuals are more likely to engage in reciprocal relationships when the other party is familiar and not "lost in an anonymous sea of others"(Axelrod and Hamilton 1981, 1395). Patterns of social organization that breed familiarity and discourage anonymity make it easier to monitor individual and collective behavior. Evolutionary biologists have observed that kin- or familybased groups are more likely to reciprocate, but even non-kin groups can engage in reciprocity (West, Griffin, and Gardener 2006). Though one might be tempted to think that reciprocity is an aberration, especially among unrelated human groups (after all, just a cursory glance at Twitter or the local news reveals a wealth of selfcentered and hostile behavior), cooperation is common, but not always easy, even in "one-shot" interactions (Fehr and Fischbacher 2004; Fehr and Gächter 2002; Fehr and Rockenbach 2003; West, Griffin, and Gardener 2006).

Even among non-kin, familiarity can be established through a set of shared understandings of appropriate or wrongful behavior, called norms. In effect, unrelated people can become "like kin" when they agree, even tacitly, to engage in exchanges and follow communal rules or norms (Stack 1974). How these norms develop is a subject of continuing debate. Some scholars contend that they develop out of sincere beliefs in what one should or ought to do, and others maintain that they emerge from an unconscious self-interest in how a community should conduct itself (Elster 1989; Hajj 2016). Regardless of their source, norms or shared understandings generate rules of behavior (such as those governing the sending of remittances to distant kin) because they are easy to replicate. Ease of replicating the norms in a variety of geographies helps them persist (Elster 1989). Replicable norms are critical in generating a sense of connection and patterns of expected behavior within a community (Scott 2009).

The existence of norms is not enough to ensure that people will adhere to them. Norms of appropriate and wrongful behavior must be enforced. Enforcement is dependent on repeated interactions and the presence of a party with enough power or will to reward compliance and punish defection (Axelrod and Hamilton 1983; Fehr, Fischbacher, and Gächter 2002; Fehr and Rockenbach 2003). Repeated interactions are important because when parties are likely to meet again in the 
future, if one party effectively defects in one encounter, then the other party will have the opportunity to retaliate in the next encounter (Axelrod and Hamilton 1981, 1395; Axelrod 1984).

Even in situations where selfishness would be very easy, because of fewer encounters and less observable action, reciprocity may occur if there is an enforcer. Fehr and colleagues consider how cooperative relationships arise even in contexts in which pure self-interest would cause a breakdown in reciprocity. They find that cooperation happens when a community has a strong reciprocator, or an individual with a "predisposition to reward others for cooperative, norm-abiding behavior, and a propensity to impose sanctions on others for norm violations" (Fehr and Rockenbach 2003; see also Fehr, Fischbacher, and Gächter 2002). In other words, reciprocity is more likely to occur when there is someone who acts as an enforcer of community behavioral norms.

There is evidence that enforcement of social norms involving sharing food or collective action is likely to occur even if enforcement is costly e there is no guarantee of in-kind rewards. Strong reciprocators can fundamentally affect the aggregate outcomes of social interaction because they change the incentives of selfish types in a population (Fehr, Fischbacher, and Gächter 2002). Over time, through social learning and imitation-that is, cultural transmission-a contextually specific "manual" for cooperation and punishment evolves at a rate that maximizes fitness. The studies by Boyd and colleagues (2003) and Fehr and Gächter (2002) indicate the overlap of proximate and ultimate causes of cooperation. They show how and when culturally specific strategies of reciprocity mix with strategies promoting long-term survival or fitness.

These studies on the proximate causes of reciprocity suggest how Palestinian refugees in the Nahr al-Bared camp might use ICTs to facilitate community building and economic remittances with their transnational diaspora. Louise Cainkar's studies $(1999,2006)$ of Palestinian American women in Chicago, Sarah Gualtieri's (2019) research on Syrian Americans in California, and Loren Lybarger's (2020) research on Palestinians in Chicago also demonstrate the power and reach of norms in encouraging and enforcing reciprocal exchanges in maintaining transnational diaspora-refugee connections. For example, Cainkar (1999, 2006) studies how families choose marriage matches in America that benefit relationships among families still in the refugee camps or business engagements with other Palestinian Americans that increase and stabilize the flow of wealth back to people in the camps. Melding diaspora studies and reciprocity scholarship can help predict when reciprocity is likely to emerge, even when violence, time, and distance may separate communities and when members of those communities are not necessarily biological kin. Reciprocity is likely to emerge among refugee diaspora networks when there are social groupings or patterns of social organization that breed familiarity and discourage anonymity; connection among people is based on easily replicable shared norms of expected behavior; there are repeated 
interactions; and there is a strong enforcer with a willingness to reward adherence to a set of culturally specific behavioral norms and punish deviations from those norms.

\section{THE ADAPTIVE VALUE OF PALESTINIAN PRECRISIS NETWORKS AND NORMS}

Extending the scholarship on reciprocity to refugees and digital spaces provides an opportunity to witness community resilience even in the face of a broken international order. It shows how refugees can generate vital economic remittances to fund public goods and welfare services with little or no state or aid agency involvement.

The first step in generating nearness among diaspora in digital spaces is to use and project patterns of relationships that breed familiarity and avoid the anonymity that the digital world and transnational distances can engender. There are myriad ways to organize a Facebook group, a WhatsApp messenger chat group, or a photo-sharing page. However, strategically emphasizing the familiar, and in some cases the familial, is critical for incubating reciprocity. Despite the challenges of living in refugee camps for more than seventy years, Palestinians have developed strategies for preserving and resurrecting their family and village identities, and these are reflected in digital refugee spaces.

Family, tribe, and village structures have rooted the Palestinian people and offered a shared understanding of how to resolve problems and maintain cohesion amid instability (Hajj 2014, 2016). In particular, Palestinians share what Roy (2001) and Sayigh (1979) refer to as the "primary" identities of blood (family, clan, tribe, and ethnicity), place (village, neighborhood, city, and country), and religion, which is predominantly Sunni Islam. Ahl, or family, and hamula, or village-clan, are particularly salient units of social organization and "world making" for Palestinian refugees (Bowker 2003). This network or web of family-village connections was a valuable bulwark against outsiders in times of ambiguous rule and conflict, such as during the Ottoman Empire and the British mandate, and remains relevant even today (Bowker 2003; Hajj 2016; Lybarger 2013; Roy 2001; Sayigh 1997). Bowker notes, "Palestinian refugees in general possess a sense of imagined community, in that the group is defined not by a geographic space but rather the creation and reproduction of a social organization or networks not located in a specific place" $(2003,67)$. This sense of imagined community is "oriented toward sustaining kinship ties." It is preserved in refugee neighborhoods and reflects, in broad terms, the social structures of pre-1948 Palestine. Map 1 shows how residents of the Nahr al-Bared camp organized themselves according to their villages of origin and thus kept the villages "alive." Using these networks, Palestinian refugees "rebuilt lives socially, commercially, and employment ties with compatriots from their own towns and cities of origins" (Bowker 2003, 69). 


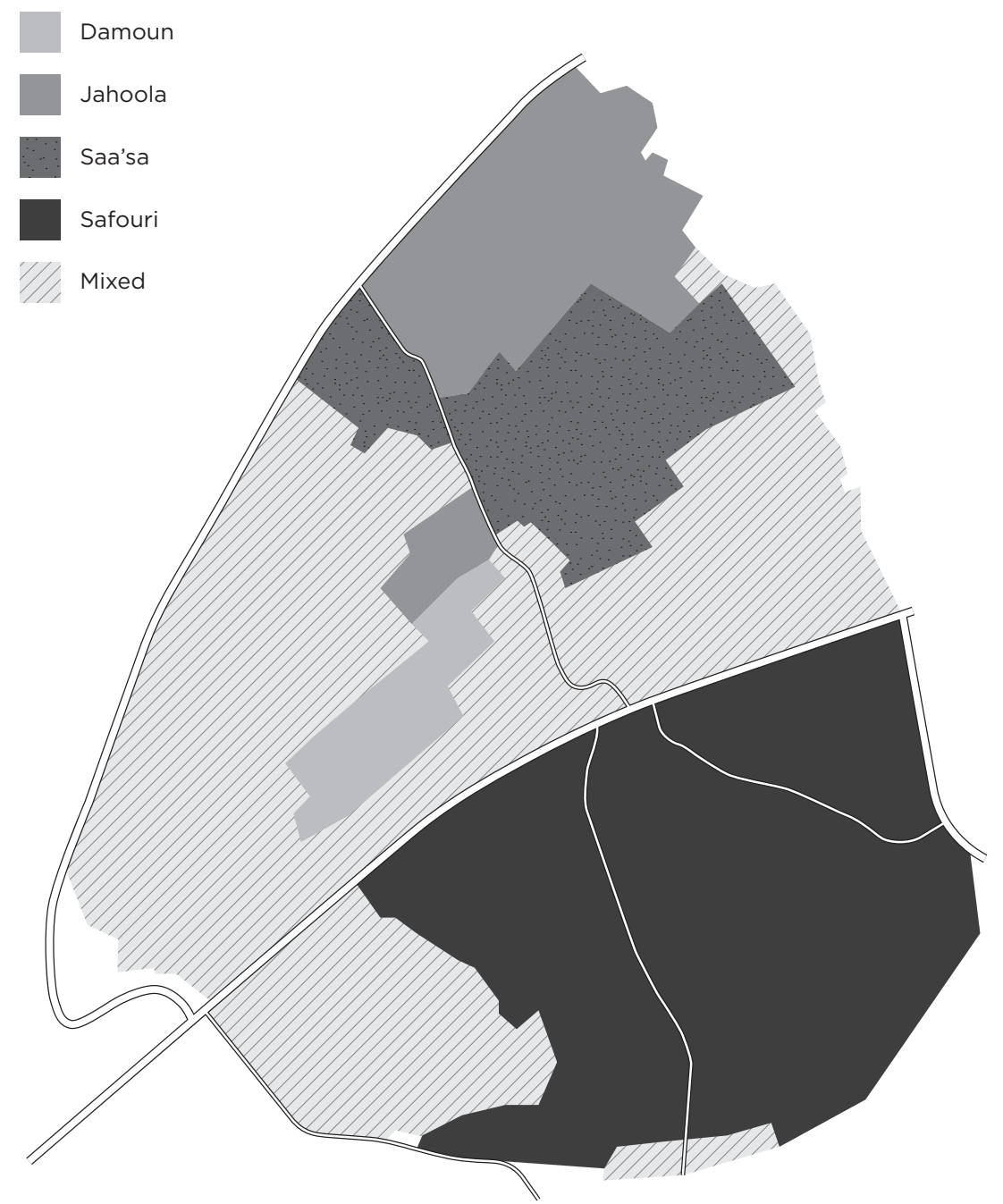

MAP 1. Contemporary map of pre-1948 village groupings in Nahr al-Bared refugee camp.

$A h l$ and hamula networks were crucial for surviving and thriving in fawdah, or the chaos of camp life (Hajj 2016). Yezid Sayigh remarks that the ghettoization of Palestinian refugees within colonial empires and host countries "reinforced the tendency of Palestinian peasants to conduct as much of their lives as possible within their villages, not replaced by camps, in which UNRWA, rather than national government, provided virtually all the basic services and jobs" $(1997,47)$. ICTs offer another opportunity to redeploy established units of social organization and behavioral norms to meet contemporary challenges. A proliferation of ahl- and hamula-based ICT platforms helps generate a sense of familiarity among 
multiple generations of camp residents and members of the transnational Palestinian diaspora. Beyond building on ahl and hamula patterns of social organization, ICT spaces devoted to creating reciprocity between Palestinians across borders must emphasize easily replicable norms of behavior (Elster 1989), using the digital dissemination of images, videos, narratives, and memories to underscore how one should behave toward the community in order to generate reciprocity and reflect culturally specific and relevant codes of behavior (Boyd et al. 2003).

The ability to extend easily replicable pre-Nakba communal patterns and norms into digital spaces has likely arisen because, as research has shown, refugee and stateless communities are particularly resilient in the face of chaos and selectively draw on their community's social networks and norms to meet contemporary challenges (Hajj 2014, 2016; Scott 2009). In difficult conditions groups strategically convert parts of their group history to manage assets and insulate themselves from the tumult of the outside world (Hajj 2014, 2016). For example, Scott's study of "fractured" indigenous groups in the Zomia in the Art of Not Being Governed (2009) helps clarify how stateless people strategically dip into their well of communal experience to protect themselves in challenging spaces.

Whereas many scholars view norms as stable reservoirs of culture and practice, Scott maintains that "traditions among stateless people are the jellyfish, shape shifting, pliable form of custom and law. They permit a certain 'drift' in content and emphasis over time-a strategic and interested re-adjustment" to confront life on the political economic margins of states (Scott 2009, 230). It is a "political calculation" to use certain aspects of their identity and history to combat the power structures and gaps in protection by states (Scott 2009, 244). For example, at times some groups asserted particular historical ties and family connections in order to ally with a reigning authority. If its leader lost power, a group would abandon particular claims and emphasize different aspects of its identity to appear favorable to the new power. Strategic conversion of identity has an adaptive value. The more turbulent the social environs, the more frequently groups fractured and recombined (Scott 2009, 259, 233).

In the same way, Palestinians have strategically deployed aspects of their history to protect their community and gain access to necessary and valuable resources. I have mapped this process with regard to the formation and evolution of property rights in Palestinian refugee camps across Lebanon, Jordan, and Syria (Hajj 2016). That study demonstrates how Palestinian refugees draw on traditional social units of organization, like their ahl and hamula, to define expected group behavior using codes of behavior anchored in their pre-1948 experiences (see Davis 2010) but adaptable to current conditions. They have negotiated property sales, adjudicated conflicts, and negotiated claims on the basis of notions of honor, shame, steadfastness, and loyalty (Hajj 2016). One would expect these coded norms of behavior to be replicated and digitally broadcast on ahl- and hamula- based ICTs to the diaspora through images, videos, narratives, and shared memories. 
According to reciprocity scholars, frequent interactions remind people of their connection with camp residents and offer an opportunity to reward or punish particular behaviors. To encourage reciprocity, digital spaces should facilitate frequent interactions between and among camp residents and the diaspora (Axelrod 1984; Axelrod and Hamilton 1981) and enable the community to share news and information in real time.

This ties into the fourth component of how Palestinians might engender reciprocity in digital spaces: through the presence of a strong reciprocator who can enforce norms or expectations of appropriate behavior (Fehr and Rockenbach 2003). The ultimate enforcer of norms, codified into formal rules or laws, might be the state (North 1995; North and Thomas 1973). However, in Palestinian refugee camps, largely devoid of state protection or intervention, community elders serve as reservoirs of community wisdom and arbitrators of conflict. The ahl and hamula serve as the key decisionmaking units and enforcers on matters such as marriage, divorce, inheritance, social security arrangements, and land disputes (Bowker 2003, 70; Hajj 2016). Usually the family patriarch, the oldest living male relative, has the final decision on issues of importance. This is evident in patterns of property ownership and enforcement (Hajj 2016) and the predominance of endogamous (clan) marriage in the refugee camps and the diaspora (Bowker 2003, 70). According to one person I interviewed, elders in the ahl and hamula have "wisdom as to how we should live together and how community loyalty should be maintained. They also have authority to force people to do the right thing if people are inclined to shirk" (I-111L).

In digital spaces, however, Palestinian elders are rarely the enforcers or gatekeepers. Though they may have power in the "real" world to enforce communal norms when it comes to business, marital, or property contracts, on digital platforms it seems likely that the platform managers serve as additional enforcers. ICT platform managers have the ability to reward diaspora members who send remittances by featuring them in a post. They also have the power to punish indifferent or negligent diaspora members by shunning and ostracizing them on digital message boards. At times, the technology gatekeeper may reinforce real-world norms; but their decisions might also deviate from community expectations, and therein lies a potential problem.

Even when patterned on community traditions and beliefs, technology has the potential to disrupt the very foundations of a community. In The Seventh Sense, Joshua Cooper Ramo considers how digital relations disrupt real-world relations. In the short run, real-world actors are crafting platforms and driving digital relations, but in the long run, these digital relations transform the gatekeepers and enforcers. He asserts that "mastery of gatekeeping" is the key to control of the networks (Ramo 2016, 2). By linking our bodies, our villages, and our ideas through ICTs, we introduce a genuinely new dynamic to our world: the technology creates dense concentrations of power that can be harnessed in new and potentially disruptive ways by new gatekeepers (Ramo 2016; Padgett and Powell 2012). 
Digital networks of Palestinian refugees are generating spaces for new conversations that empower new generations of Palestinian stakeholders inside the camps and in the wider diaspora (Ashtan 2020). The new gatekeepers may develop different ideas about appropriate behavior through online exposure to new ideas and people. The transnational flow of new ideas-what Levitt $(1998,2001)$ refers to as social remittances - and disruption of the traditional power base of community elders have the potential to undercut the established networks and norms that were originally harnessed in digital spaces to rebuild the community.

In summary, in the midst of a protection gap, refugees may fund their own public goods and reimagine their community identity by using old kinship networks melded with new technologies to engage the diaspora. Refugee communities, like Palestinians in Lebanon, show how technology may facilitate reciprocity and remittance flows when digital spaces are patterned on precrisis family and village networks; when they replicate and broadcast communal norms of honor, loyalty, resilience, and shame; when they are frequently updated; and when they are enforced through the authority of both community elders and technology gatekeepers. At the same time, ICTs may empower new actors and forces that can undercut the very networks necessary for community reciprocity.

\section{RECIPROCITY, REMITTANCES, AND STATE BUILDING}

The strategic formulation of reciprocity in digital spaces among transnational Palestinian refugees is not simply a reactive coping mechanism within a global neoliberal context; nor does the intense focus on village and family identity neuter larger political aspirations. Palestinians are members of a transnational diaspora actively engaged, in person and online, in constructing conscious ideas and embodied feelings of who belongs to the Palestinian community. Because of their continued dispossession, thwarted state-building attempts by the political elite, and abandonment by the political establishment, Palestinian refugees in camps and their transnational villagers, particularly from camps outside the Occupied Territories, engender sustainable forms of diasporic identity and belonging via reciprocity and remittances. These strategies contribute to a powerful subnational identity, distinct from the nationalist aspirations embodied by the predominant Palestinian political parties like the PLO-Fatah and Hamas, that is especially resonant for Palestinians outside the OT.

Most scholarly work on nationalism and state building in Palestine situates the process in the OT and contends that it is driven by nationalist political groups like Hamas and the PLO, the military and economic strategies of those groups (Brand 1988; Krause 2017; Jamal 2005), and their nationalist narratives of Palestinian authenticity, as opposed to Israeli "otherness" (al-Hardan 2016; Khalidi 1997). Since the signing of the Oslo Accords in 1993, Palestinians living in camps in Lebanon, Jordan, and Syria have been formally and informally marginalized from the state-building project (Sayigh 1994; Hammer 2005). Palestinians living 
in the diaspora are almost entirely excluded from any discussion about the future of Palestine (Davis and Kirk 2013, 6). When diaspora Palestinians are mentioned, it is usually with regard to how effectively competing political parties consolidate their power and loyalty inside the camps (Brand 1988). Moreover, the refugees living in camps outside the Occupied Territories are largely ignored by researchers as independent agents for political change, even though the numbers of Palestinians in the West Bank, Gaza, and Jerusalem are vastly outnumbered by those documented as refugees or resettled elsewhere around the globe (;Hammer 2005, 11). Indeed, the role of the Palestinian diaspora in crafting their own sensibility and strategies is often overlooked. Some academics seem to hold an idealized vision of Palestinian nationalism and how it is enacted in daily life. As with the documented disjuncture between scholarly imaginations of Tibet and the actual politics of that space for everyday Tibetans (Dodin and Rather 2001), there is dissonance between the understanding of Palestinian nationalism and state building among scholars and the daily lived experience for the vast majority of Palestinians.

There is a growing academic counternarrative to this limited view of Palestinian world making. Some scholars are turning their attention to an alternative, transnational community-building endeavor among Palestinians in refugee camps outside the OT and the diaspora. In her extensive interviews with young Palestinians in America, Thea Abu el-Haj describes their deep knowledge of cultural, religious, social, and political life in their bilad (homeland) and the way it is reenacted in the United States. This knowledge is transmitted largely through filial connections that generate a sense of economic and moral obligation to support the community financially and champion justice (Abu el-Haj 2015, 51, 56). It is a sense of Palestinian subnational identity, identification with their ahl and hamula, that anchors their vision and support of a free and just Palestinian state.

In his extensive studies of Palestinian families in Gaza Camp, Bethlehem, and, more recently, the Palestinian diaspora community in Chicago, Loren Lybarger (2013, 2020) also observes that the communal identity and strategy for self-determination may be rooted in village and family networks. He contends that religious and secular parties have failed to galvanize Palestinians refugees and the diaspora to their cause. To assuage their fundamental existential anxiety and develop trust in other people, he argues, it is essential for Palestinians to establish and sustain "a biographical continuity," or a coherent narrative of self in relation to others across time and space in the category of "home." Local identities will grow and intensify to regain this sense of security (Lybarger 2013, 159). Again, for Lybarger, the subnational communal identity inspires a sense of economic and moral duty to Palestine.

For example, Lybarger shares the story of Abu Jamil's family conflict in the Gaza camp. Within the family were people who identified with Fatah and some who had more recently aligned with Hamas. Abu Jamil was increasingly disenchanted with elite politics altogether because he believed it divided and weakened the Palestinian family network. He rhetorically asked Lybarger, "Why die for a 
bunch of corrupt leaders from the 'outside' who lived in ostentatious villas and hired Sri Lankan maids while everyone else was left to eke out a miserable existence in the camps?" (Lybarger 2013, 165). He preferred to focus on his neighborhood, village, and family and traditional values to help keep the community alive and thriving. Abu Jamil shared the story of a friend in the camp who sewed clothes for Abu Jamil's family without his ever having to ask. In exchange, Abu Jamil provided electrical services without asking for payment. For Abu Jamil, traditional communal values anchored in the family and village were critical to the success of the Palestinian people. In his view, declaring loyalty to a political party over one's family would erode the very bedrock of the community. Abu Jamil's family was torn apart and divided over such competing loyalties. Unfortunately, his brother declared loyalty to Hamas and began turning his energy and attention to the party instead of the family. He married a woman who supported Hamas rather than someone from within the ahl or hamula. In the end, this prompted Abu Jamil and his brother to build walls to separate their living spaces in the family home. Though it was an extreme example, Abu Jamil considered his brother's choices as a betrayal of norms that were essential to communal survival and moral wholeness in favor of a political faction that would sell out to the highest bidder at the first opportunity. According to Lybarger (2013), for Abu Jamil "the only authentic identity, the sole source of security, lay in familial and neighborly systems founded on the ethic of reciprocity, an ethic that was at the core of the 'adat wa taqlid (customs and traditions) of the hamula and its fellahin (farmer) peasant ethos" (166).

Palestinian village networks and norms, both in person and in digital spaces, are not insular, tribal, inherently selfish, apolitical, or premodern. The subnational identity does not reify neo-orientalist visions of the region as a tribal space incongruent with the "modern" world (Lybarger 2013; Peteet 2008). Recent empirical studies by Singh $(2015,2017)$ show how subnational regional and village identities in India were creatively mobilized to provide solutions to health and welfare problems that benefited communities beyond a particular region or village. Similarly, subnational family and village networks generate both a moral and economic site of world making for Palestinians in real-world and virtual spaces. Networked refugees are using reciprocity and remittances to solve collective problems and thereby incubate an embryonic state administrative capacity rooted in a flexible and distinctively Palestinian sensibility of what it means to belong to and serve the community. Although ICTs may give rise to new voices that undercut the power of established gatekeepers, norms, and tropes, they provide space for a more expansive understanding of Palestinian identity (Ashtan 2020).

\section{RESEARCH METHODOLOGY}

In this book, I use information obtained from computer data scraping, hundreds of in-depth interviews, and dozens of surveys of diaspora members across 
the Middle East region, Europe, and North America to show how transnational Palestinian refugees outside the OT are strategically using digital spaces to encourage remittances that solve collective problems and provide public goods. I used a multipronged approach to assess the central hypothesis that digital spaces patterned on precrisis social networks motivate reciprocity and generate economic remittances. I conducted research on the behavior and motives of community-building stakeholders in three distinct but overlapping sites: inside the Nahr al-Bared refugee camp, with the Palestinian refugee diaspora around the globe, and in digital spaces where camp residents connect with the extensive diaspora network. Each research site required a different set of tools.

First, I conducted interviews with Palestinian refugees living in Nahr al-Bared, from a variety of $a h l$ and hamula networks, to understand their access to and usage of ICTs. The interviews are listed in the research appendix. I interviewed Facebook group page managers, refugees between the ages of 18 and 25, middle-aged men and women, and people over the age of 65. I endeavored to get a representative sample, though I relied on snowball sampling to identify interested participants. I began by initiating conversations with members of families originally from Samoie village because of my established connections with them (Hajj 2014, 2016). However, I also interviewed members of families from Damon, Safouri, Saa'sa, and other villages.

Next, I conducted eighty-two survey interviews with Palestinians from a variety of villages who grew up in Nahr al-Bared and are currently living in North America, Australia, Europe, and the Arab Gulf region to gain an understanding of their internet usage and reflections on digital and real-world communication with the refugee camp. I initiated contact using the telephone or digital meeting apps like FaceTime, WhatsApp, and Skype. These surveys are described in detail in the research appendix.

Finally, I "scraped" data from digital sites identified by camp and diaspora respondents using a tool called Selenium WebDriver to analyze user demographics, the content of digital conversations, and the intensity of engagement in relation to geographic location. Usually used for web application testing, Selenium WebDriver allows users to write code that, among other capabilities, clicks on web page buttons, enters text into text boxes, and scrapes text and links from websites to help verify whether a web application is working as expected. My unconventional use of this tool involved using Selenium WebDriver scripts to scroll through the Facebook pages of Palestinian families and villages to obtain data on who comments on posts on the Facebook pages, the geographic location of the commenters, and the content of their comments. Using the Python programming language in conjunction with Selenium, these scripts were run on a variety of posts on the village Facebook pages over a period of more than one year. The posts were selected to represent a diversity of topics, including obituary and funerary remembrances, 
marital celebrations, political campaigns, and business openings. Research was focused on the Samoie village Facebook group page because I received permission from the Facebook page manager, users, and the Wellesley College Institutional Review Board (IRB) to analyze and use the content of specific posts for publication. Although the IRB regards this type of data as public and does not require user permission, in order to maintain my own ethical research standards, I sought the consent of every user when running an analysis or using an image. I used my entire methodological toolkit to gain a comprehensive understanding of refugee ICT usage, reciprocity, and remittances in digital spaces.

\section{THE STRUCTURE OF THE BOOK}

In chapter 2 I map Palestinian ahl and hamula networks in analog and digital spaces. Prior to 1948, Palestinian villages were accustomed to ambiguous rule and shifting power dynamics. They were adept at managing community needs and solving dilemmas within the family and village networks. Even when the community experienced the Nakba and moved to the refugee camps, the family and village remained important to survival. As the generation who had grown up in Palestine began to pass, and more camp residents migrated seeking economic opportunity, the community developed a "geography of the displaced," or a moral space, represented in village history books, where the community could craft and rebuild their family and village community.

Using Davis's (2010) excellent analysis of Palestinian village history books, I examine how the community initially sought to connect with new generations and the diaspora. These books are valuable reservoirs of shared stories and values. However, they suffer from the limitations inherent in analog tools: they are largely static representations of the past, because they are not easily updated, and their readership is limited because of the cost of production and difficulty in dissemination. Palestinian digital spaces offer a reinterpretation of the village history books. In the latter half of the chapter, I catalog the vast number of ICT platforms patterned on ahl and hamula networks. I highlight the activity on the digital pages, describe the type and content of digital posts, display the number and activity of users, and map the diaspora networks.

In chapter 3 I show how these vibrant digital connections engender real-world action. I trace how one Palestinian hamula Facebook page used particular images, videos, narratives, and memories to build connections and reproduce Palestinian norms of honor, shame, steadfastness, and loyalty. Building on Stack's (1974) ethnography of poverty and gift giving among Black Americans, I find that gift giving is an adaptive strategy of the poor. In addition, I examine the Amish practice of shunning, which provides a useful analogy to Palestinian practices of shaming and punishment. Through extensive interviews with Palestinian camp residents 
and surveys with the transnational diaspora I trace how the replication of traditional norms in digital spaces inspires economic remittance flows that fund desperately needed public goods and services.

In particular, I examine how the real-time broadcasting of Palestinian burials and the needs of critically ill individuals and promising young students in digital spaces remind people living outside the camps of their connection and duty to those left behind. In the absence of state and aid-agency funding, the transnational Samoie village diaspora raised more than US $\$ 20,00$ to fund a facility in Nahr al-Bared for washing the bodies of the dead before burial and to provide burial shrouds so that all families in the camp, not just those from Samoie, could bury their loved ones with dignity. They also raised $\$ 10,000$ to fund a skin graft for a child burned in a fire and the annual tuition fee of $\$ 6,000$ for a young woman in medical school. These initiatives demonstrate the community commitment to honor and support the next generation of Palestinian refugees, with the expectation that these young people will pay it forward in their turn. These community successes were spotlighted in digital posts.

Despite the success, reciprocity is not universal among those in the diaspora with financial means. I explore how the community enforces norms of honor and loyalty by shunning shirkers online and imposing financially costly punishments on their extended families in the real world. The use of shame is an effective tool for sanctioning repayment of gifts, but it runs the risk of alienating already marginalized community members. I briefly explore the dark side of shame as a tool for community sanctioning and highlight how some family units are pushing against patriarchal strictures and adopting more expansive notions of Palestinian identity and norms in order to encourage the younger generation to remain connected to the community.

In chapter 4 I examine the flow of new political ideas into the camps and the tensions between digital guardians of community norms and real-world enforcers in Palestinian refugee camps and the diaspora. The flow of social remittances from the diaspora to those in the camps prompts new positions on the establishment of a Palestinian state, financial remittances, and transnational activism. Yet the empowerment of new digital gatekeepers also has the potential to disrupt the very traditions and norms that initially anchored the community.

Chapter 5 summarizes the main findings and lessons learned from Palestinian experiences. ICTs are particularly effective in generating reciprocity and remittances when they are patterned on familiar social groupings, are updated with relevant information, transmit replicable norms of appropriate behavior, and are maintained by both real-world and digital gatekeepers. The book concludes with a blueprint for reciprocal activism among those of us motivated to support refugees and other struggling communities. With ICTs, activists and advocates do not need to reinvent the wheel to supply desperately needed remittances. We do not need huge organizational structures or large operating budgets to make a 
real difference in the daily lives of refugees and others who are suffering. Direct engagement with others over the Internet can transform conflict settings into more-just spaces. After connecting to the Internet with our smartphone or other digital device, we can complement existing refugee community networks, listen to refugees' needs and requests, and buoy them with our own resources to close the protection gap. 


\section{Mapping Palestinian Ahl and Hamula Networks in Analog and Digital Spaces}

After the 1948 Nakba, Palestinians were thrust into chaotic conditions, with little guidance or assistance from host states or humanitarian agencies on how to provide for their basic needs. With many states focusing on their own postwar reconstruction, the international community was ill-prepared to handle Palestinian needs. Newly independent Arab states pursued nationalist agendas, and rural Palestinian communities were not easily integrated into their state-building plans (Brand 1988).

Yet from the Palestinian perspective, ambiguous political economic conditions in the refugee camps were not entirely new: Palestinians were inured to shifting regional and imperial political powers with varying levels of oversight (Davis 2010; Hajj 2016). One self-described camp historian at Nahr al-Bared noted: "Some people like to think that the moment we arrived in the camps was our 'first rodeo, like the Americans say, in surviving bad times. But you know what? Stories from the village and my own dim memories of life before 1948 remind me that our family and village were used to getting things done on our own terms long before we set foot in Nahr al-Bared. We knew how to stay together and find collective solutions to our problems even when the world didn't care for us" (I-57L).

Expanding on this refugee's reflection, I examine the ways in which ahl and hamula kinship structures served as anchors and the 'adat wa taqlid moored Palestinians even as political turbulence threatened their survival during Ottoman rule and the British mandate. In particular, I examine pre-Nakba jana'iz, or Muslim burial practices, as evidence of how the community strategically used their 'adat wa taqlid to obtain collective goods and services denied to them by the imperial power.

This communal strategy for solving problems helped refugees survive life in the camps. Palestinian families continued to cluster in village groupings. Over 
time, as young scouts migrated for economic opportunity, the community developed what Rochelle Davis refers to as a "geography of the displaced"-a space where the camp community could craft and rebuild their family and village connections (2010). Davis's excellent analysis of Palestinian village history books describes how refugees reconstitute and reconstruct their villages in ways meaningful to their lives in the camps. With the passing of the last generation of Palestinians to grow up in Palestine, subsequent generations have migrated for economic opportunity, relying on digital technologies to remain in contact with family members in the camps.

Palestinian digital spaces offer a new form of the village history books and help sustain-and reshape-community behavioral norms. These digital spaces enable reciprocity and remittances to flourish among transnational diasporas. In the latter half of the chapter, I catalog the vast number of ICT platforms patterned on $a h l$ and hamula networks. I also describe the type and content of digital posts and the number and activity of users, and map transnational Palestinian refugee diaspora networks..

\section{STRATEGIES FOR BUILDING COMMUNITY COHESION AND MEETING NEEDS BEFORE 1948}

Throughout the eras of the Ottoman Empire and the British mandate, Palestinians were accustomed to ambiguous rule and shifting power dynamics. They were adept at managing community needs and solving collective dilemmas their family and village kinship networks. Farsoun and Zacharia (1997) and Nadan (2006) identify pre-1948 Palestinian village government practices. They argue that patrilineal structures of kinship linked community members in both real and imagined ways, creating the bedrock of community trust that underpinned political and economic transactions in the absence of a state or outside authority (Nadan 2006, 196).

The central patrilineal units of the Palestinian village were the ahl and hamula. The hamulas regulated and guaranteed "access to productive lands and the rights of individuals over them" (Farsoun and Zacharia 1997, 23). These units were both genealogical and imagined, meaning that people could be considered cousins or brothers even if they were not biologically related. One effect of these familial and imagined bonds was to deter family members from actions that would dishonor and shame the family in communal dealings.

Patrilineal kinship ties established norms of behavior and formed the basis of agreements. As Nadan observes, "Patrilineal understandings [of community dealings] were not signed in the manner of official contracts, as this would be regarded as 'ayb or shameful" (Nadan 2006, 196). Nadan found that the Palestinian farmers or fellahin preferred to barter rather than push for cash transactions within the community. They trusted that they would be paid, sometimes many months after 
an exchange, because they shared kinship ties. "The village barber for instance, was paid in kind for his services once a year at harvest time, and a carpenter would receive measures of wheat in return for maintenance of plows and for other work" (Nadan 2006, 174). ahl and hamula also protected individuals and kin during external conflicts. "Led by their own sheiks or religious leaders, the hamulas therefore provided the individual within the nuclear family collective protection in all aspects of his or her life" (Farsoun and Zacharia 1997, 23). An old Arab proverb highlights this way of thinking: "Me and my brother against our cousin, and me and my cousin against the stranger." As a result of these traditions, Palestinian refugees in Lebanon, mostly hailing from the rural places studied by Nadan and Farsoun and Zacharia, had easily replicable notions of honor, shame, and loyalty to anchor transactions in the chaos of the refugee camps.

\section{PRE-NAKBA BURIAL PRACTICES}

A close examination of burial practices highlights how Palestinians handled problems and encouraged cooperation using familiar social groupings and shared norms of honor, shame, and loyalty prior to the Nakba. Similar patterns of behavior are evident with regard to the negotiation of endogamous clan marriages (Bowker 1993), business contracts (Farsoun and Zacharia 1997; Nadan 2006), social relations (Davis 2010), and property titles (Hajj 2016). Firsthand accounts and memoirs reveal that the community sought to affirm ahl and hamula cohesion, steadfastness, and collective self-reliance in the face of shifting political powers. One interesting historical account also suggests that when a Palestinian died while migrating westward for economic opportunity, the family honored the dead, pooled resources to perform Islamic burial practices, and affirmed community village and family ties in preference to seeking state support (Grant 1921). The accounts of pre-1948 burial practices that I share indicate a reservoir of flexible funerary practices from which the Palestinian community could draw in the refugee camps after the Nakba.

My initial understanding of pre-Nakba burial practices developed out of a long conversation with Dr. Anthony Sahyoun, a Palestinian surgeon trained in Britain. As a member of a prominent family as well as a medical professional, Dr. Sahyoun attended many funerals in Haifa during the mandate era. Though he came from a prominent Christian family, he also attended funerals of Jewish and Muslim Palestinians because of his family's business network.

I was particularly interested in his recollections of Muslim burial practices because most refugees in the camps were Muslim. Many Christians stayed behind or found other accommodations as citizens in neighboring Lebanon, Jordan, or Egypt, including Dr. Sahyoun's parents and siblings. Most Jewish Palestinians remained after the war. Dr. Sahyoun recalled the pre-Nakba Muslim burials: 
There was no wake for the body like the Christians. The body was washed right away and wrapped in a shroud, and prayers were said by the imam over the body at the cemetery. There was no casket, just the shrouded body. I remember much fewer religious rituals than the elaborate Christian burials. So the burial ceremony was simpler for Muslims. I recall only men attended the funeral for Muslims. We shared a simple communal meal, the entire village paid for it, with family and close friends afterwards. Women were not allowed. If a person was very well known, then more family and friends attended the ceremony of the individual. It was a villageand family-centered practice.

These simple burial practices emphasized honoring the dead and supporting the circle of friends and family above all else.

Dr. Sahyoun's recollections are echoed in the writings of nineteenth- and twentieth-century European travelers to the "Holy Land," and Palestine in particular. Although many of these memoirs are rife with orientalist commentary and bias, they still contain useful descriptions of "native" burial practices. Moreover, not all of these travelers identified as entirely "European." The Reverend G. Robinson Lees, the vicar of St. Andrew's Church in Lambeth, spent his youth traveling and serving in Palestine. His book Village Life in Palestine (1905) gives a thick description of Palestinian peasant life and practices. Initially, he describes a Palestinian family's anguish at the news of a death: "When the hand of death is laid on one of the inhabitants of a village [in Palestine] the cry of woe pierces the soul and shrieks of distress awake the slumbering people and re-echo through the vales of the surrounding country." The body is quickly prepared for burial: "The clothes of the deceased are removed, the jaws are bound up, and the eyes are closed. The Khateeb washes the body, covers it with a sheet, and places the corpse on a bier. If death took place in the morning, interment follows the same day; but if the deceased expired in the evening the burial is performed on the following morning" (Lees 1905, 128).

In describing the gravesite practices, Lees notes that the Islamic prayers are chanted repeatedly, and the body is buried in a communal burial plot located close to the village. The salat al jana' $i z$, or funeral prayer, and the procession to the graveyard are a fard kifayya, a prescribed religious duty that requires a representative part of the community to participate. In this way, family and village cohesion is maintained even in death. "A hole is hastily dug in the cemetery, the resting place of the village fathers nearby; the body is carried on a bier by the men of the family and village, walking at a moderate pace and chanting incessantly the Moslem profession of faith (the shahada): 'La illaha illaha; Mohammed rasool ullah; Sallallahu 'alayihi was sellam.' 'There is no Deity but God; Mohammed is the apostle of God: God Favour and preserve him.' " At the grave, "Words of praise are uttered on the dead in feeling tones as the body is laid beside the tomb, then the Khateeb calls on the spirit of the departed to answer as he would in the presence of God, and say he 
has been a devout Muslim. In his stead a relative replies, 'He believed in one God and Mohammed the Apostle of God.' The body is laid in the grave and covered with earth. Day after day the grave is visited until a headstone marks the place of rest" (Lees 1905, 129).

Another account provides a vivid tale of the murder and subsequent burial of a local man from the Khaled family. After a description of an intravillage feud that resulted in the murder, we learn about communal funerary traditions in the midst of violence and crisis. "Less than an hour afterwards the dead man's people came and carried him home." The corpse was quickly prepared for burial: "The body was thoroughly washed, sewed up in a fresh shroud and carried to the tomb that same evening. A dead body must never remain unburied lest the land be defiled" (Baldensperger 1913, 124).

Members of villages from both sides of the feud attended the burial rites: "Friend and foe joined in the procession: some to mourn, others to secretly rejoice." These observances were followed by a remarkable process of communal reconciliation. "The Khaled family provided for the funeral supper given to as many as chose to be present and show their sympathy for the bereaved. Before this supper every man present embraced the other as a token of reconciliation in the presence of death, and the bereft were greeted with the words: 'Salamat Rasak-Your head is safe' " (Baldensperger 1913, 124). This account of a violent death suggests that even at times when clan links might understandably be strained, ahl and hamula bonds prevailed, and community members cooperated to properly bury the dead man and feed the mourners.

At the time, Ottoman law decreed that Palestinian murder cases should be judged by the tribunal at Jerusalem. However, the family council felt they ought to act alone and to take vengeance as a family to "end the shame" (Baldensperger 1913, 124-25). This observation indicates that the family and village sought to control the narrative of the death rather than surrender that power to the Ottoman Empire.

Elihu Grant describes an early-twentieth-century burial in his book Peasantry in Palestine: "Death among peasantry is an occasion for long mourning. The body is wrapped, placed in the ground, and protected from the falling earth as well with the use of stones. On top of the grave the heaviest stones obtainable are packed to make it difficult for the hyenas to secure the body. It is customary to watch the grave for many nights to keep these creatures away." He writes that family and village networks share in the tasks of carrying the body to the grave and in offering communal meals after the interment. The "bearers take turns assistant in carrying the body to the grave and visitors from other villagers come to assist in mourning for the deceased. They are provided with food and shelter while they remain" (Grant 1921, 99-100).

Grant describes a poignant moment when a family learned of the death of their son during his emigration to Mexico. ${ }^{1}$ Despite the absence of the body, the community observed the burial traditions. "One of the saddest cases that came 
under my observation was that of a young man, who leaving his family, emigrated to America in search of a fortune.... When the news reached RamAllah, the grief was keen. It is customary at such a time for the women to go either to the threshing floor or to the cemetery to mourn. But in this case, as the man was buried far away, the women assembled on a small piece of ground that was owned by some of the tribe where there was a fig tree. They sat under this talking until the company increased to over forty women.... A circle was formed and the women marched to the accompaniment of the mourning song" (Grant 1921, 100).

The gathering of women from the family and several villages to talk and to mourn the dead man highlights the importance of both honoring the dead and reaffirming village and family social bonds in the face of uncertain conditions. Grant goes on to describe the mourning song about the dead man, Butrus (Peter) and his widow, Nameh (Naomi). The closing stanza of the song summarizes the community's remembrance of the dead and the strength of kinship ties and values even when a death occurs far from home. The song also reiterates the importance of finding a home with family:

O ye stranger bearing the coffin, wait until his family arrive.

$O$ ye strangers bearing the coffin, wait until his kinfolk come.

The grave of Butrus by the road is in neglect; He wants a guide to lead him Home.

(Grant 1921, 103)

\section{THE NAKBA}

In November 1947, a United Nations resolution created the state of Israel, a small territory roughly the size of Massachusetts that had been inhabited for 1,200 years by an Arab majority (Smith 2010). On May 14, 1948, Israel proclaimed its independence. Palestinians refer to this historic moment as the Nakba. The partition and subsequent war over the territory between Israelis and Palestinians in 1948 and 1949 prompted the first refugee crisis to confront the newly formed UN and created a catastrophe that persists today. The ongoing codification of Palestinians' dispossession through a variety of legal statutes has worsened their suffering. Contested historical accounts provide different understandings of these events. ${ }^{2}$ What is indisputable is that 1948 marks the genesis of the Palestinian refugee crisis and the establishment of Palestinian refugee camps.

The crisis left most Palestinians with few assets and little more than the clothes on their backs (Schiff 1993). Initially, Arab governments bore most of the responsibility for refugee relief. In August 1949, the United Nations Clapp Mission assessed the repercussions of the 1948-49 war and the potential solutions. In total, the mission estimated that there were 726,000 refugees, of whom 652,000 were classified as "in need." The magnitude of the Palestinian refugee crisis prompted the mission to recommend forming an organization dedicated to handling it. On December 8, 1949, UN Resolution 302 created the United Nations Relief and Works Agency for 
Palestine Refugees in the Near East (UNRWA). UNRWA's humanitarian services encompass primary and vocational education, primary health care, relief and social services, infrastructure and camp improvements, and emergency response, including in situations of armed conflict. It officially began operations on May 1 , 1950 (Brand 1988, 150).

Originally there was no provision in UNRWA's mandate for determining who qualified as a Palestinian refugee and therefore was eligible for assistance (Takkenberg 1998, 69). A provisional definition of eligible persons developed as relief work was conducted inside the camps (Hajj 2016) and was revised several times over the years. To qualify as a Palestinian refugee, "a person must have lost his home and livelihood and reside in a country where UNRWA operates" (Takkenberg 1998, 68). UNRWA now provisionally extends refugee status to descendants of these refugees, though Takkenberg points out that there is still "no valid legal definition of a 'Palestinian refugee' beyond the provisional definition of UNRWA" $(1998,68)$. Successive generations of Palestinians living inside the camp and in the transnational diaspora can claim and identify with the title of "refugee" even if they draw no benefits or services from UNRWA.

On December 3, 1949, shortly before the creation of UNRWA, the UN General Assembly adopted Resolution 319, which established the United Nations High Commissioner for Refugees (UNHCR). The Resolution 319 legal statutes were adopted a year later at the Convention Relating to the Status of Refugees of 28 July 1951, known as the 1951 Convention. The convention established a universal definition of refugee status and prohibited the forcible return of refugees. The definition applied to all refugees after January 1, 1951-with the exception of Palestinian refugees displaced in 1948. Arab states feared becoming responsible for the support of Palestinian refugees if the 1951 definition was applied to them. These states proposed an amendment to the 1951 Convention draft that explicitly excluded Palestinian refugees who were already supported by UNRWA. This created a deliberate "protection gap" for Palestinians. Even today they occupy a legal gray area that prevents any international or regional stakeholder from laying legal claim to the protection of, or legal sovereignty over, Palestinian refugees (Knudsen 2009, 53-54).

\section{REFUGEE CAMP FAWDAH}

Describing early life in the refugee camps, one refugee commented, "In the beginning, it was only fawdah" (chaos) (I-4L). After the 1948 war, most Palestinians were thrust into unfamiliar surroundings in host countries across the Middle East. Many Palestinians from the Safad region in northern Palestine ended up in the Nahr al-Bared refugee camp. For example, the villagers of Samoie, an agricultural farming community near Safad, grew olives and cereals. Their village had a school, a mosque, and a cemetery serving a population of around 360 . The village 
was ethnically cleansed on May 12, 1948, in Israeli Operation Hiram (Palestine Remembered, n.d.). Villagers were forcibly exiled to the southern Lebanese border, then transferred to Nahr al-Bared in northern Lebanon in 1951 (Hajj 2016). In 1998, the population of Samoie refugees was estimated at roughly 2,208. One refugee recounted:

I was a young child, but I will never forget what I saw in 1948. I was only five years old, but it is etched in my memory for all time. I came upon a barn in our olive grove and encountered my uncle strung up in a barn and burned. His death was a warning from the Israeli soldiers and frightened all of us. We made preparations to leave as soon as possible. Stories were coming from nearby villages of the violence and death and the looting that was happening at checkpoints. The men and teenage boys went ahead in the night and escaped across the border, and they scouted for a place for us to live near the border in Lebanon. One uncle stayed behind with all the women and children, and he shepherded us and all our stock of goats through the checkpoints. We took turns carrying the young babies because our mothers were also carrying our few valuable belongings. In the bands of the children's underpants they hid their gold and valuables because the Israeli soldiers were taking people's gold at the checkpoints. They rarely checked young children, and that's how we were able to save our gold, which we used to fund the initial year in Lebanon. My mom sewed gold into my underpants. It gives new meaning to the idea of "family jewels!" Ha! But, we made it across all together. Our family and village survived and stayed together. (I-112L)

Besides meeting the refugees' most basic human needs, aid organizations and host states offered little support for governing the camps or rebuilding the community. Palestinians had to manage the transition from rural villages to camp life on their own. Another refugee, now a cinderblock and tile manufacturer, described the early years: "We started from scratch in the camps. There was nothing. We pulled ourselves out of the dirt" (I-28L).

Certainly, Palestinian refugees in the camps lacked material wealth and wasta, or connections to elite networks of wealth and political status. According to Dr. Sahyoun, the majority of urban, wealthy Christian and Jewish Palestinians never set foot in the camps. Robert Bowker corroborates this assertion: "Most of the urban refugees in 1948, all of them Christians, and members of the propertied classes from the villages, never entered the camps" (2003, 69). The Sunni Muslim fellahin classes were isolated in the camps.

It is not entirely true, however, that Palestinians came to the camps with "nothing." They were adept at deploying familiar patterns of social organization and easily replicable 'adat wa taqlid to access valuable goods and resources without the assistance of a state or aid agency. Palestinian $a h l$ and hamula identities persisted even when Palestinians were catapulted into refugee spaces. Rochelle Davis elaborates on this notion, observing that Palestinians have "carried their village and city names, memories, hopes, tragedies, and possessions with them into the diaspora. Despite the destruction of the physical landscape, village names continue to be 
part of Palestinians' everyday lives." She notes that streets and businesses inside the camps bear the names of familiar pre-1948 places and sites of memory, which were common vernacular among refugees in the camps (Davis 2010, 3).

In particular, Palestinian camps are patterned on pre-1948 ahl and hamula groupings (Sirhan 1975, 2). Old village dynamics and patterns of interaction are reproduced in the camps. Though they were geographically destroyed, the camps have kept the villages alive from a social and cultural perspective (Hajj 2014, 2016). For example, map 1 shows how the geography of the Nahr al-Bared camp reflects the residents' origins from pre-1948 villages from the Safad region of northern Palestine, like Damoun, Jahoola, Saa'sa, and Safouri. Samoie villagers also lived together in a cluster of homes, though it does not show up on the map provided because of its small size. Additional maps that illustrate the village living patterns are documented by UNRWA ("Pre-War Urban Fabric of Nahr el Bared," n.d.) Communities stuck together after 1948, for better or worse (Hajj 2016).

With meager resources and little prospect for socioeconomic mobility in the host states, Palestinian villages inside the camps sent community scouts abroad to find jobs and earn money. Young Palestinian men regarded migration to the Arab Gulf states, in particular, as a golden opportunity to earn money in the oil and construction industries and build a better life (Brand 1988; Hajj 2016; Rubenberg 1983). ${ }^{3}$ There was a strong communal expectation that these young men would send the majority of their income to family members in the camps. Levitt (1998, 2001) notes that this is a common pressure on early community scouts. Many young Palestinian men shared cramped apartments in the Gulf states and Libya for years to save money for their families. One older Palestinian who grew up in Palestine, fled to the camp in 1948, and was an early migrant to the Gulf states and later to America recalls the pressure he felt to send remittances back to his family and what it was like to feel the weight of the entire community's hopes, dreams, fears, and financial goals:

I did not have the luxury to choose jobs or school programs that had prestige but offered me little money. I had my entire village to support-I had younger brothers whose entire education was paid for by me. My father's medical bills for a hip replacement-yes, that was also paid for by me. My sister's marriage dowry-yes, that was also supplemented by me. When I came to America for my doctorate, I was offered scholarships to all the Ivy Leagues like Yale and Princeton and Dartmouth. If I was selfish, I would have taken them. I know those names mean something to most Americans. But I also needed more than a scholarship, I needed a large stipend and the ability to have a paid internship at an engineering firm while getting my doctorate in economics. My family and village had placed their faith in me, and so I reciprocated. I negotiated with a scholar at the University of South Carolina interested in recruiting me. He paid me a substantial stipend and secured me a high-paid position at a well-known engineering firm. I was also able to work with the South Carolina Department of Transportation. USC was so good to me, and so was Prof. S. He remained a lifelong mentor because I think he knew the weight of pressures 
I faced. Anyways, I worked like a dog and sacrificed a lot of fun that my peers at school probably experienced. But it was the right thing to do to honor my family and maintain a good reputation. I know what it is like to starve, to have not bathed in a week, to have no spare clothes, to fear how the family will survive the next day, and I would never abandon them, even if I sacrificed some of myself for them. (I-112L)

During interviews, business owners inside the camps said that housing and building improvements were financed primarily by remittances from by family members working in the Gulf states or Libya. Residents revealed that remittances were the primary source of investment capital, especially for startup business loans, because budget constraints and the high demand for loans made it impossible for most businesses to rely on UNRWA or bank loans (I-11L, I-2L). As a result, "most of the money that permitted refugees to initially invest in their homes and business in the camps came from remittances sent by family members" (I-2L).

\section{VILLAGE HISTORY BOOKS}

In Palestinian refugee camps, ahl and hamula bonds contextualize individuals' place in the world and maintain community ties even in a scattered transnational village. Palestinian refugees have strategically deployed pre-1948 community practices for maintaining cohesion in a changing political and economic landscape that they are largely powerless to control. Even before the internet era, Palestinians used patrilineal kinship ties and norms of behavior to reimagine the Palestinian community. These ties are exemplified in the village history books they crafted after their arrival in the refugee camps.

Palestinian refugees are a population with a common origin story - the 1948 war-and shared aspirations for statehood, but they do not share many contemporary experiences because the population has been fractured and dispersed across the globe. In the face of these strains on connection, village history books provide a cohesive narrative of shared heritage. The books record the pre1948 history of life in Palestinian villages through written and oral recollections recorded by a village member and then bound into a book. They describe the villages in ways meaningful to those currently living in camps and the diaspora. They provide a way for displaced villagers to reconnect to their geographic home. Davis observes that these books have enabled refugees to participate in creating their present and their future. Capturing their memories in history books was an effort to work against seeing their culture and values as bounded and static. The books portray Palestinian values and ways of life as a pool of memories, ideas, and understandings that can be adapted to meet contemporary challenges (Davis 2010, 3).

Village history books may be thought of as a means of generating connection and reciprocity among the camp and diaspora family and village members. They are patterned on existing village and family networks. For example, a book may 
represent one family or one village. The books provide narratives of pre-camp life, with clear expressions of behavioral norms that still obtain. They are generally written by well-educated camp residents, like writers, schoolteachers, and civil servants (Davis 2010, 5).

The creation of these books is a local and collaborative effort that is subject to intense scrutiny, both during the writing process and after publication. The books' authors serve as gatekeepers and enforcers of particular historical narratives and norms of behavior. Davis found that the vast majority of village books are written by men $(2010,34)$. She acknowledges the limitations of village history books in providing specialized versions of the past that highlight only some stories and very particular values at the cost of a more representative past; but she sees them as effective in reminding younger generations of Palestinians in the camps and the diaspora of their duties to their family and village. The village history book of the coastal town of Salama, for example, describes the tomb of Shaykh Hasan: "It is a holy shrine (maqam) for the people of the village; the women made a sacrifice to it and visit it to place candles. This maqam fills people with amazement because the Zionist occupation has tried to destroy it a number of times. Their bulldozers break down by some miracle and cannot destroy it. So instead they put a fence around it and left it" (quoted in Davis 2010, 175).

Davis includes these accounts not to assert their veracity but to demonstrate how the community uses the story of tombs "to resist their own destruction and symbolically mark for Palestinians the (failed) attempts of others to erase their presence and history" (2010, 176). The books convey "a set of utopian but not incorrect visions of what was important rather than an event based history" (Davis 2010, 71).

The authors of these histories are explicit in considering the books as a resource, or marja', for the children of today and the future (Davis 2010, 52-53). The books call on the young to struggle against their dispossession by remembering how their ancestors acted and to reproduce those actions. Village history books reinforce norms of reciprocity by focusing on the collective values of "honor, generosity, and cooperation." They emphasize the well-being of the village collectivity, al awna, above all else (Davis 2010, 71).

In the history book for the village of Abu Kishk, one man tells the story of the village's relations with the neighboring village of Kafr Thulth. In the story, Abu Kishk runs out of wheat and intends to trade gold for wheat with a family named Dar Hilal (Davis 2010, 72-73). A village member from Abu Kishk sets out with a camel caravan loaded with payment. However, Farha, a wealthy man from the family of Dar Hilal, refuses to honor the arrangement to sell his wheat, and the caravan is turned away. On the route home, the man from Abu Kishk encounters members of Farha's family, who denounce their relative's behavior. Later, a man named al-Hassan from the Dar Shraym family of Kafr Thulth village encounters Abu Kishk's camels. Al-Hassan loads the camels with his wheat and 
refuses payment for it. "He wouldn't take any money but instead said, give my regards to the elders [mashayikh] of Abu Kishk" (quoted in Davis 2010, 73).

According to Davis, the story "contains within it norms of behavior and the values that the villagers held in esteem, and demonstrates their ability to censure an individual and evoke these norms in order to achieve their ends" (2010, 74). Examples like this from village history books provide a culturally specific blueprint for good behavior and reciprocation, reinforcing traditional norms even in camp and diaspora life (Lybarger 2013).

Although these books are reservoirs of shared stories and values, they suffer from limitations inherent in many analog tools. While they were crafted through collaborative processes, they are largely static representations of the past because the high cost of publication precludes updating them. Also, the books have a limited readership because of the cost of production and the difficulty of disseminating them except through specialized bookshops (Davis 2010, 12, 34-36). Interestingly, in the conclusion of her book, Davis predicts that new digital platforms centered on the village structure and communal norms may help connect the younger generations of Palestinian refugees scattered around the world.

Palestinians in the diaspora have, however, engaged in additional forms of world making. Thea Abu el-Haj asserts that even before "Skype and Facebook were commonplace, these [diaspora] families were in constant contact with relatives 'back home' and ... often remarked how quickly news of their activities, especially rumors about impending engagements, reached their relatives in the bilad" (2015, 51). Studies have shown that Palestinians in American diaspora communities worked daily to cultivate a sense of their Palestinian "home" connections while living in exile. This connection to home should not be taken for granted or assumed (Cainkar 2006). The sense of being Palestinian is not an "essential" condition of the diaspora: rather, it reflects "everyday, ongoing work that produces" a diasporic culture that affirms the centrality of ahl and hamula (Abu el-Haj 2015, 46).

One way that scouts with families cultivate connections to their village and family is by reenacting village life in the diaspora. For example, Abu el-Haj shares a poignant story of young American Palestinian couples carrying out village rituals during the wedding season. In late spring, the beginning of the wedding season, Abu el-Haj was schooled by her young interviewees in the etiquette of delivering wedding invitations: "They drew out maps of each house in the neighborhood to which an invitation to Khalida and Leila's sister's wedding had to be-as they explained-hand-delivered. This process of walking around and visiting neighbors while hand delivering wedding invitations felt resonant with small village life in Irdas [their Palestinian village]. In many ways, these young people felt they were part of an extended village" $(2015,52)$. The young Palestinians were acutely aware of how the village community mapped onto their American neighborhood and of how this network connected to their pre-1948 village structures and norms. These Palestinian diaspora children were part of a reimagined, transnational Irdas village. 


\section{CONNECTING IN DIGITAL SPACES}

Village history books were used to affirm a common background and shared values among young generations of Palestinian refugees around the world (Davis 2010). These early analog versions of village making helped the community remember their history, share information with extended family, and encourage diaspora scouts to send remittances. But the high cost of producing and distributing these books limited their influence. With the proliferation of ICTs, Palestinians entered a new phase of village making and transnational camp-diaspora connections. Digital spaces offer further opportunities for Palestinians in the diaspora to develop economic and moral connections to their Palestinian family and village.

ICT platforms like Facebook are certainly not a cure-all for collective dilemmas of providing public goods and services, but they do offer a digital space for connection. Scholars of cooperation theory hypothesized that digital spaces would be especially effective for generating reciprocity and remittances when spaces were patterned on familiar social groups, referenced easily replicable norms, provided frequent and repeated interactions, and were managed by "strong reciprocators."

In the following discussion I take a close look at the Samoie village Facebook page. Examining activity and analyzing interactions on the page, I found that the Palestinian refugee camp community primed itself for reciprocity and regular remittance flows by patterning its Facebook pages on pre-1948 ahl and hamula communal groupings, projecting easily replicable 'adat wa taqlid through accessible images, videos, and sayings, regularly creating new digital content, and eliciting comments and posts from the transnational diaspora.

My initial conversations in the camps regarding ICT usage began with the family of Mayssareh Salah el-Haj, known in the community as Abu Raed, a Samoie villager who had lived in Nahr al-Bared since 1950 and the camp's unofficial poet laureate. In 2012, I had my last conversation with Abu Ra'ed. In June 2017, a contact in the camp notified me of his death and asked if I had seen a post about it on the official Samoie village Facebook page. I was surprised to learn of his death and even more astounded to learn that there was a Facebook page that documented occurrences like deaths, marriages, births, college graduation celebrations, and shop openings inside the camp. I quickly contacted the family to offer condolences, and after observing the customary one-hundred-day mourning period, I began interviews with the family to learn more about his death and the decision to announce his death online. I was curious to learn whether the digital representation and projection of Palestinian family and village news on Facebook pages was commonplace.

Abu Ra'ed's brother explained death observances in Nahr al-Bared and how critical ICTs are for engaging the ahl and hamula around the world: "When my brother died, we shared the news in a variety of ways. Of course, the local mosques and sheiks declared the news inside the camp. We also called immediate family via cell phones using WhatsApp and Viber. Our relatives and the Nahr al-Bared 
internet forum shared the news via their Facebook pages. We alerted the entire village living in Nahr al-Bared and around the world of his death. It was a chance for all of us to come together and mourn him" (I-10oL).

Hoping to get a better idea of ICT usage patterns in the camp, I was introduced by Abu Ra'ed's family to another refugee family from Damon village, who had also recently lost a family member. The eldest daughter shared the story of her father's recent passing.

My dad was born in Damon, Palestine, in 1937 and came to Lebanon during the Nakba. He had a small sundry shop to support our family of twelve. I know, twelve! He had a lot of responsibility with his family, but he never complained and always worked hard for us. He was a really good dad and a really good Muslim, and I am not just saying that because I have to speak nicely of the dead. He was such a good man. Anyways, he died of natural old age in 2016. It was five in the morning when he died at home in bed, and we did not delay in his burial. We buried him the very same day at twelve noon in a grave alone. He is one of very few who had his own plot in the cemetery because he was so old. We buried him fast, this is our Muslim way, and only people living in the camp-his family, friends, neighbors, villagecould attend. But even if people could not be there physically, everyone came together. We shared the news of his death through traditional means like the mosque and sheiks and with very modern means too. We used things like WhatsApp, the Nahr al-Bared internet forum, the Damon Facebook village page, and individual family member Facebook pages. The key was that our family and village inside the camp and all the relatives and villagers living outside the camp in Croatia, Sweden, America, Germany . . c could support us emotionally. Some Damon villagers from abroad even paid for the slaughter of animals and the food for mourning meals and gift tissue boxes for the crying women and copies of the commemorative Qur'an that we gave to visitors at the memorial. We all came together, from everywhere. (I-103L)

In order to get a better understanding of how deaths and other camp community events were chronicled online, I contacted the Facebook group manager for Samoie village and requested permission to join the site. A few days later, I gained access to the Official Samoie Village Facebook Group Page. Immediately, a post popped up documenting a recent poetry reading at the camp's meeting hall in which Abu Ra'ed was featured. During his recitation Abu Raed suffered a fatal heart attack onstage. His poetry reading and death were streamed on the Facebook page while camp residents and the Samoie village diaspora watched. After his death, the Facebook page chronicled the entirety of the funerary rites online. (See figures 1 and 2 for examples. $)^{4}$ Members of Samoie village around the world could watch the shrouding of his body, listen to the prayers at the mosque, see the burial at the cemetery, and engage with the grieving process. Though the circumstances of his death and its real-time documentation on Facebook may be unique, the chronicling of his death and the response of the wider diaspora are typical of the transnational linkages on digital platforms in refugee spaces. 


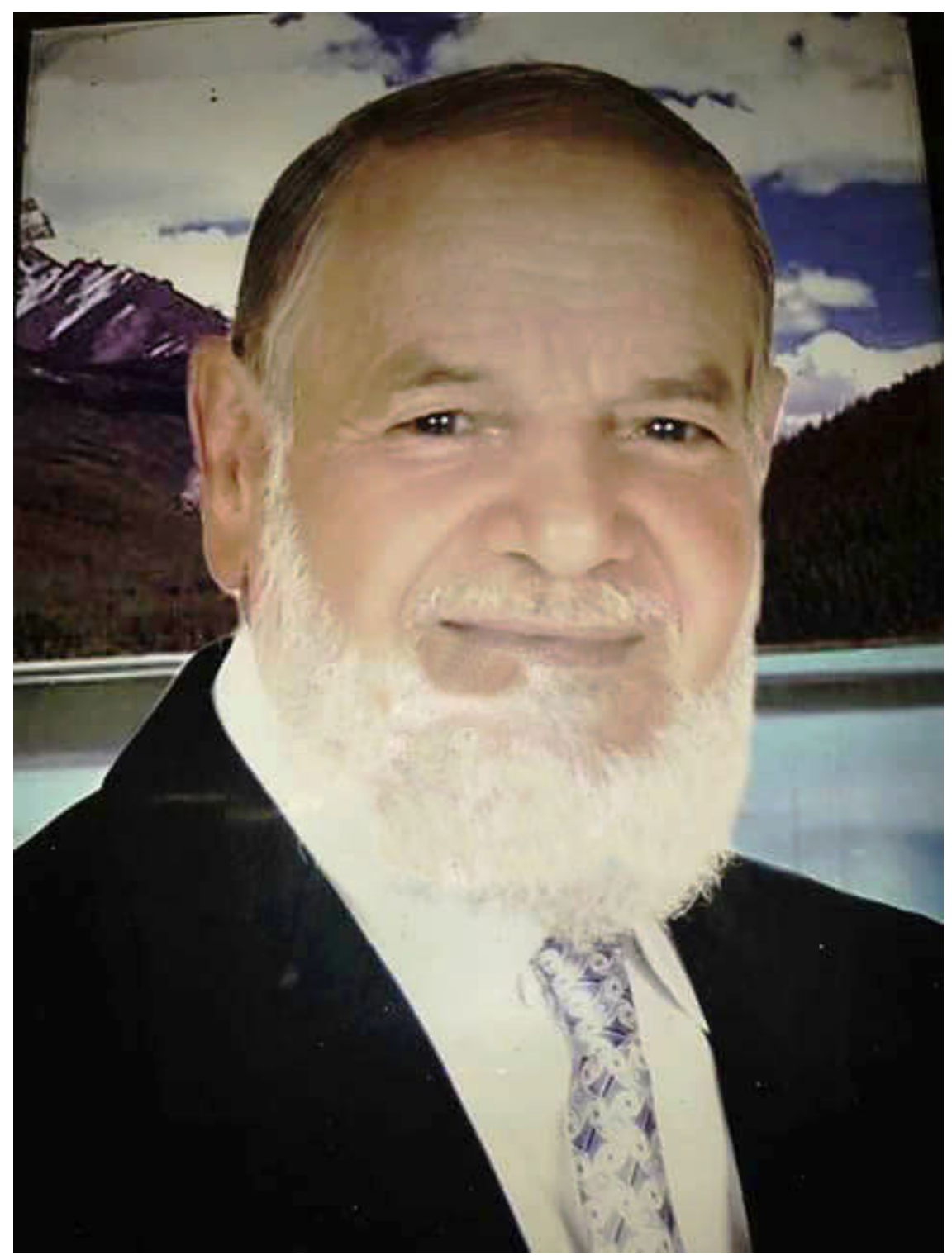

FIGURE 1. Obituary image of Mayssareh Saleh el-Haj, also known as Abu Ra'ed, posted to Samoie village Facebook page on June 17, 2017.

These posts garnered dozens of comments and links from camp residents and the diaspora. The Facebook pages provided a digital space for affirmation of village membership, personal expression, and revitalization of the traditional ahl and hamula networks. The streaming of the burial linked the transnational Samoie 


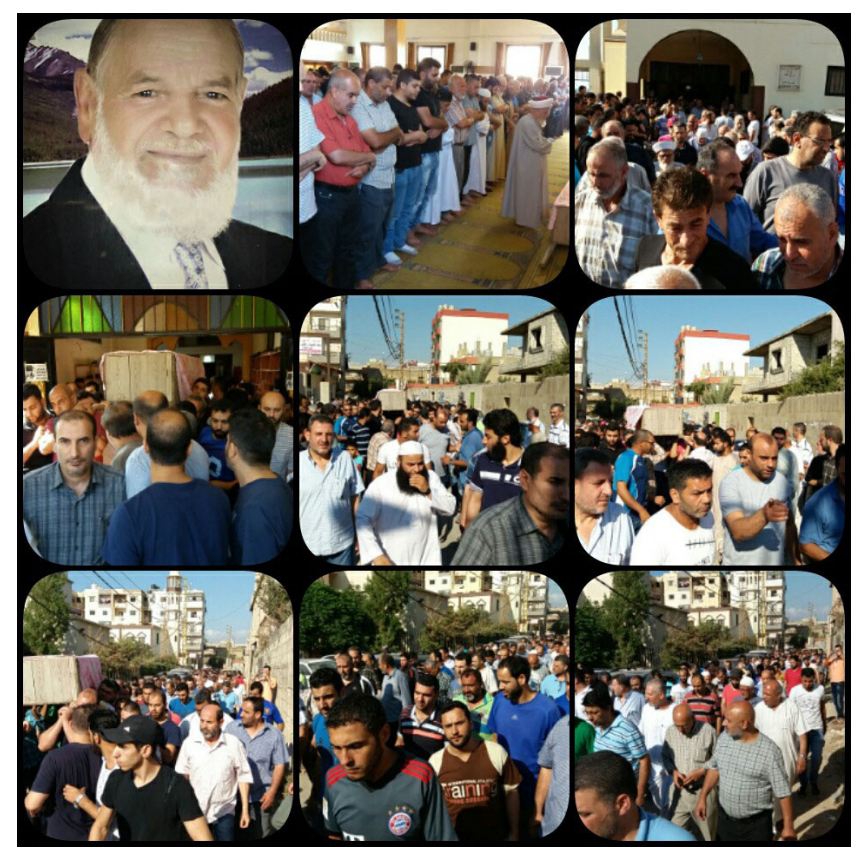

FIGURE 2. Collage of photographs of the funerary rites for Abu Ra'ed, posted on the Samoie village Facebook page on June 18, 2017.

Palestinian diaspora with their family and village in the camp. Family members could watch the community procession to the grave, eat a communal meal, and share remembrances in real time.

Map 2 illustrates the global distribution of comments on Abu Ra'ed's death and funerary rites in the Facebook group. Many of the comments (indicated with red shading) come from residents of Nahr al-Bared, in the Levant region of the Middle East, but others come from Samoie villagers in Australia, New Zealand, Croatia, Germany, and the United States (including California, Texas, and Massachusetts). A survey of Facebook pages for Palestinian villages and cross-referencing with the digital Palestinian directory Palestine Remembered, which manages village statistics for every single pre-1948 village, reveals that the Samoie village page is not unusual: more than half of all pre-1948 Palestinian villages or family networks maintain active group pages, usually on Facebook. For example, villages from the northern Galilee or Safad region, like Damon, Fara, Safouri, and Saa'sa (all of which are represented in Nahr al-Bared), maintain Facebook or social media groups that replicate pre-1948 patrilineal structures. The group pages are like digital town halls where community members can post information, advertise services, solicit help or feedback, and engage in conversation.

After the Nakba, the majority of Samoie's 360 villagers migrated to southern Lebanon (Khalidi 1997; Palestine Remembered, n.d.). By 1951, they were resettled in Nahr al-Bared refugee camp, along with residents of a host of other small 


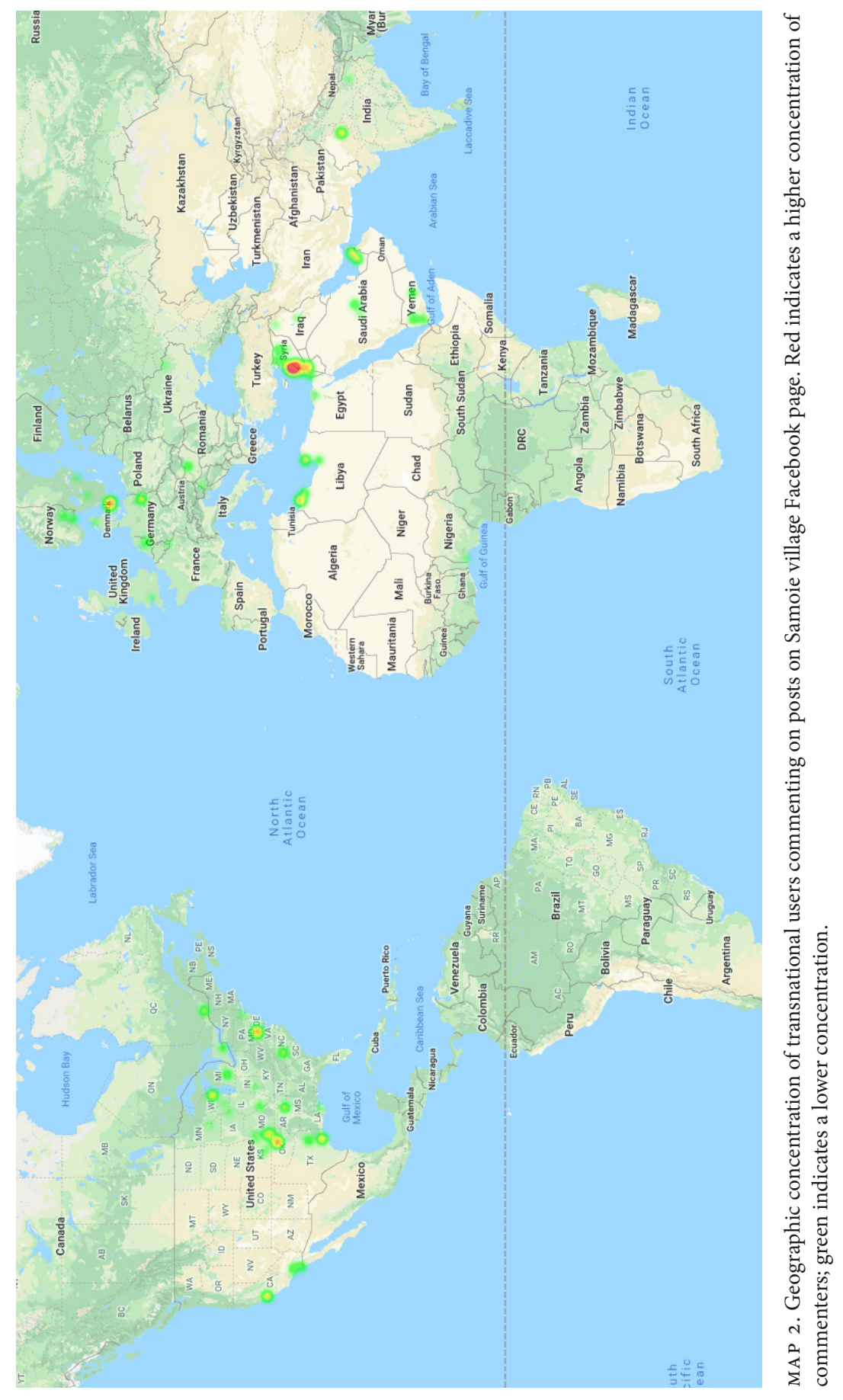


villages from the Safad area. Many Samoie villagers continue to live inside Nahr al-Bared, though a significant number have resettled abroad. The Samoie village Facebook page had 2,523 followers as of October 2020, representing a wide swath of Samoie villagers around the world $(\mathrm{I}-122 \mathrm{~L})$.

The page is managed by a resident of Nahr al-Bared who works full-time as a teacher at a UNRWA school. I asked him why he had started the page and whether anyone else in his family or village had encouraged him to do it. He responded:

I started the webpage because I have a passion for digital media and photography. I love sharing my photography and videography projects in the space. I go to most of the camp's weddings and big events and take photos and make music videos. I wanted a public platform to document it all. I didn't start the page with the intention of getting money or starting a business, it naturally grew out of my hobby. I also understood how to create a page and manage the technology. It started as a personal thing, but I like knowing that I can facilitate our people [from Samoie] connecting to one another even though we are very far apart in a physical sense. I think it keeps us feeling close. (I-122L)

By patterning the page on the Samoie village social structures and sharing news of community events, providing a space where the transnational village could mourn and celebrate together, he was unconsciously paving the way for reciprocity and the flow of remittances. The unexpected outcome of his efforts reminds me of Kathleen Thelen's (2004) insight that the architects of institutions or structures may have very different intentions than the interests those institutions ultimately serve. What began as a personal project may provide a space for collective engagement and communal problem-solving. This outcome also affirms Elster's (1989) supposition that individuals may unconsciously pursue activities that affirm structures and norms that benefit the collective.

Regardless of the intentions behind the creation of pre-1948 village Facebook pages, the groups are incredibly active. Between May 2017 and May 2018, the Samoie village Facebook page averaged 19.3 posts a month (see figure 3 ). Topics range from news of births, marriages, deaths, and national exams for high school students to more entrepreneurial notices of a new shop's grand opening, the advertisements for exam tutorial services, and requests for donations to pay for surgery or educational expenses (see figure 4). Some community members post poetry and images of "home." They scan and share pictures of their pre-1948 villages. In addition, they share links to traditional songs and dance videos and share a variety of religious musings. These posts generate lively conversations between Palestinians inside the camps and those in the diaspora.

Although the majority of the Facebook group's members reside in Nahr al-Bared, they do not dominate the conversations on the page. Figure 3 graphs the frequency of individuals' comments and "likes" on the page by geographic location. It shows that the frequency of posts does not decrease with increasing physical distance from the camp. ${ }^{5}$ Though there is clearly sampling bias because 


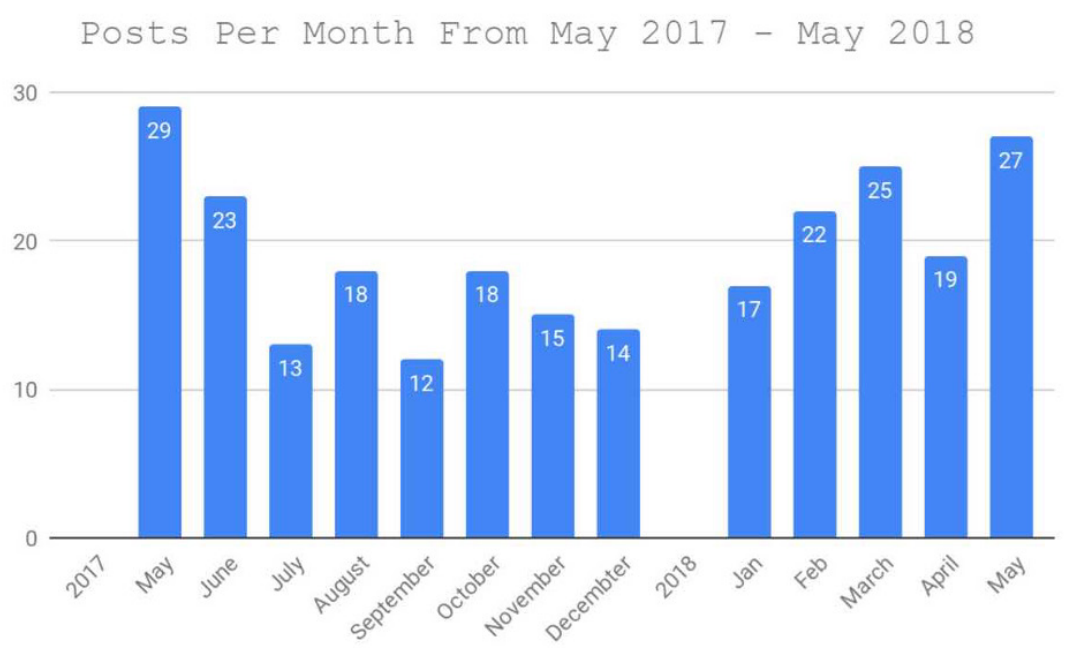

FIGURE 3. Number of Facebook posts per month on the Samoie village Facebook page, May 2017-May 2018.

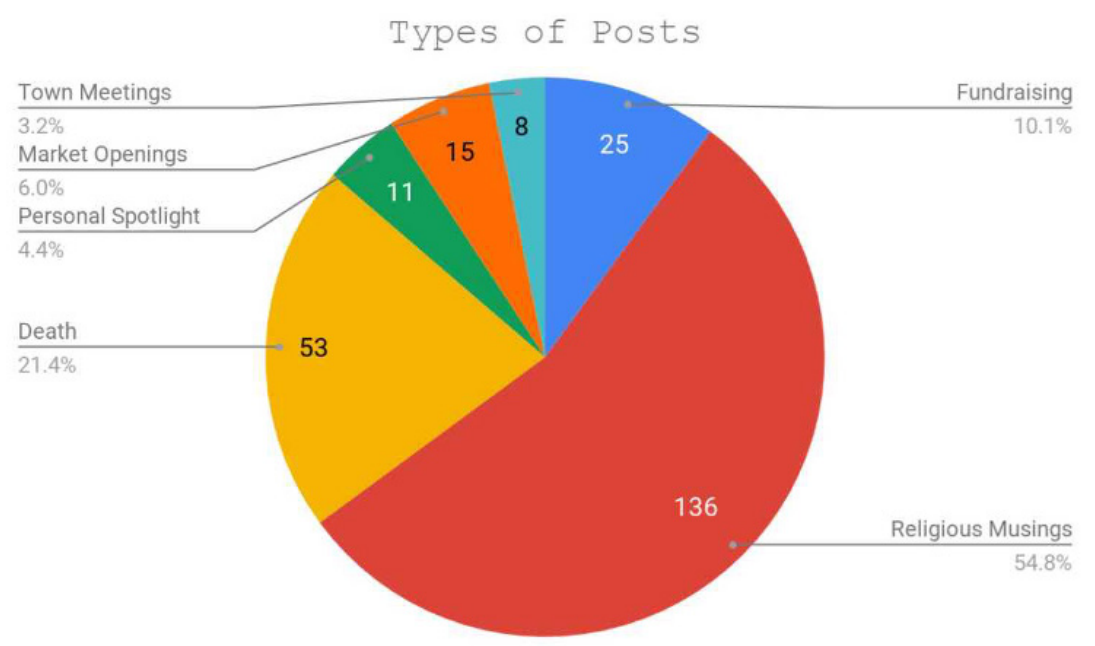

FIGURE 4. Distribution of types of Facebook post on the Samoie village Facebook page, May 2017-May 2018.

only interested villagers would join the group in the first place, the data suggest that the page generates connections between camp residents and the transnational village diaspora. In fact, even with a statistical analysis that diminishes the power of outliers, the frequency of an individual's posts is independent of distance from Nahr al-Bared. These data demonstrate regular, sustained engagement among the users with the content on the page. 

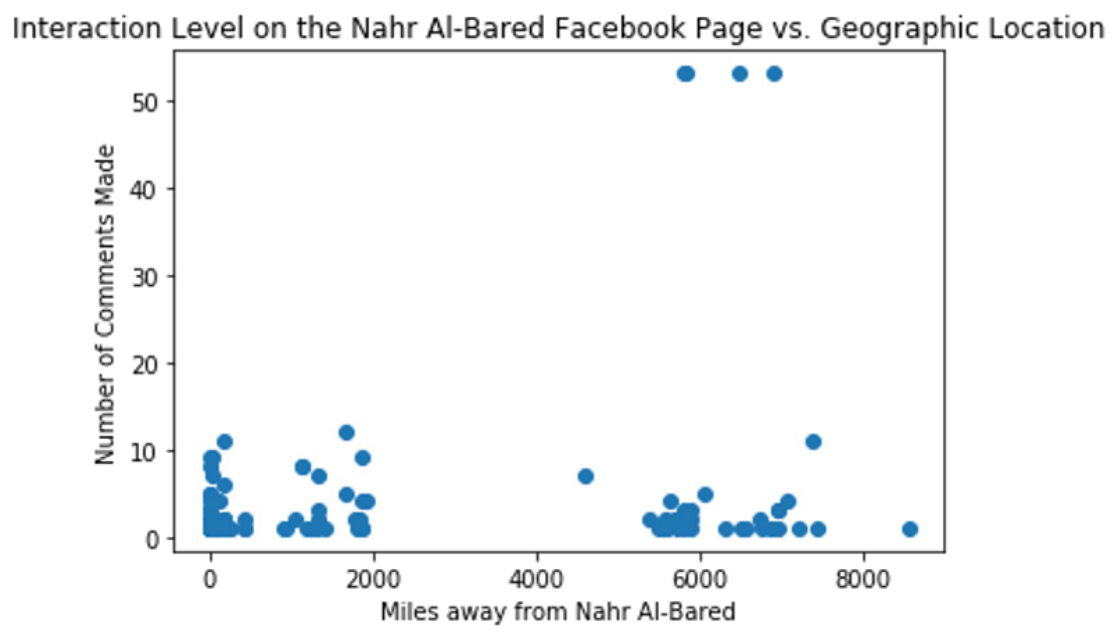

FIGURE 5. Frequency of interactions by user's geographic location on the Samoie village Facebook page, May 2017-May 2018.

These digital spaces are vibrant hubs of activity, focusing on images, videos, and narratives that affirm traditional communal values of honor, collectivism, steadfastness, and loyalty. The chronicling of Abu Ra'ed's death was not just about this particular event, any more than the story of Abu Kishk villagers trying to obtain wheat was just about getting wheat. These posts affirmed the community's 'adat wa taqlid of honoring the elderly in the community, collective mourning, the importance of awna, and the duty of feeding mourners. Lucia Volk maintains that praying and gathering at a cemetery is "world making" because it teaches important lessons of solidarity and civic duty to contemporary and future generations $(2010,25)$. She finds in her study of Lebanese funerals that cemeteries offer a place of unity and cohesion in politically divided sectarian societies. For residents of Nahr al-Bared and other camps, the online documentation of the death of a community member becomes a site of transnational village making in the face of political upheaval and uncertainty. The same applies to the announcements of births, marriages, and business openings: they affirm unity in deeply broken political and economic spaces.

Nevertheless, this abundance of online activity does not provide evidence that transnational digital communities generate any real-world action. They may engender feelings of nearness essential for motivating reciprocity, but neither village history books nor Facebook pages guarantee remittance flows. Technology pessimists might suspect that members of a transnational digital village could easily decline into a group of "smombie slacktivists" (Simanowski 2018), offering digital declarations of solidarity but no practical action, and that the community would suffer the financial remittance decay that plagues many refugee and migrant 
communities. However, the robustness of these transnational digital communities is sustained through the representation of precrisis kinship structures and their associated norms. The norms of collective loyalty, honor, steadfastness, and shame that historically organized and enforced individual and collective behavior prior to 1948 and inside the camps are effective tools for generating real-world economic remittances in digital spaces too. The next chapter considers precisely how digital connections motivate continued economic remittance flows from the diaspora to those resident in the camps. 


\section{Reciprocity, Enforcement, and Economic Remittances}

Samoie villagers in need have found the village's Facebook page an effective means of mobilizing resources through the diaspora network. In late May 2019, several images of a badly burned child from Nahr al-Bared popped up on the page, accompanied by a short narrative of the tragedy. The young boy had been playing near his father's workshop when an accident occurred, and he was burned over 80 percent of his body. He was expected to survive with proper medical attention, including skin grafts and physical rehabilitation. However, UNRWA medical aid would not cover all the costs of the procedures, and private hospitals in nearby Tripoli, Lebanon, require payment in advance. The costs of treatment were estimated at roughly US $\$ 20,000$. To bridge this gap in services in the refugee camp, the Samoie village Facebook users appealed to the diaspora network.

In April 2019, a young woman in her final year of medical school posted a plea on the Samoie village Facebook page for help paying her tuition fees. The demand for UNRWA postgraduate scholarships outstripped the supply.

Earlier, in May 2018, a well-respected sheikh passed away from a stroke on his return home from the hajj, or pilgrimage to Mecca. The community realized there was no communal facility in which to wash and enshroud his body, or anybody else's, in a dignified way. Again a transnational diaspora campaign began, to raise funds for a burial washroom via digital media platforms like the Samoie village Facebook page and the WhatsApp messaging service. In all three of these cases, the Samoie village community generated the resources to meet the community's needs.

Financial remittances are sent to the camps in three different ways. Most commonly, donors send cash with friends and family traveling to the region. One Samoie diaspora member said, "The main way most of us send money to the camps is through the shaanta, or suitcase method. There is always someone who 
is the brother or cousin or second uncle of a friend traveling to Lebanon. I give him the cash, and he manages to get it to my family network in the camps" (I-124L). This strategy mirrors the hawala, or informal money-lending system used in parts of Africa and South Asia. Many diaspora villagers also wire small emergency payments through Western Union. Though it is accessible, Western Union has costly fees and may raise red flags when people regularly send money to countries like Lebanon and Syria, as officials in the United States may view the transfers as potential security or terrorist threats. Finally, some members of the diaspora hold bank accounts in the camp host countries and use their accounts as a sort of village ATM to fund services and goods. One trusted family member can withdraw money from the bank account and distribute funds to those in need.

In the cases mentioned above, diaspora members coordinated efforts to send funds to the camp. For example, US $\$ 20,000$ was sent in digital payments to fund skin grafts for the burned child. The community found $\$ 6,000$ to pay for the young woman's last year of medical school. Contributions of more than $\$ 25,000$ covered the cost of the communal washroom (yet to be constructed), and the campaign even prompted a cemetery cleanup initiative by a camp religious organization. Contrary to the views of technology pessimists, digital spaces facilitated remittance flows from the Palestinian refugee diaspora, even among second- and third-generation community members who had never lived inside the camps or in Palestine.

In this chapter, I trace how one Palestinian Facebook page uses images, videos, narratives, and memories that reproduce a malleable form of Palestinian 'adat wa taqlid to encourage connection, mobilize the diaspora's resources, and fund needed goods and services. Building on Carol Stack's All Our Kin (1974), I show that patterns of gift exchange among people in poverty are embedded in well-defined kinship obligations and sanctions. Stack's ethnographic study of a poor Black community during the 1970s, in a space she refers to as the Flats, provides a useful comparative case for understanding poverty, reciprocity, and gift exchange among kin and kin-like groups. She illustrates the way the community invites reciprocity and enforces sanctions on shirkers. Likewise, I show how 'ayb, or shame, was used as a strategic tool for punishing shirkers and encouraging the members of the diaspora to give money and share resources with community members in need.

Though shame may seem like a weak tool compared to the formal mechanisms that a state might wield for enforcement of behavior, like a police force or established judicial system, in truth, shame is an effective informal tool for managing social interactions and encouraging reciprocal behavior. It is especially powerful among communities living separately from state structures (Kraybill 1998; Kraybill and Bowman 2002; Stack 1974). Drawing on an extensive literature, I compare Palestinian communities to Amish communities in Lancaster County, Pennsylvania that use shame and shunning, or Meidung, to enforce communal norms of obedience, loyalty, and selflessness and fund communal needs. 
While Stack's study predates ICTs, and the Amish people explicitly reject the use of digital technology in most circumstances, Palestinians who are forcibly separated by geographic distance have found a way to use digital spaces to enforce shared norms and incentivize remittance flows. By patterning digital spaces on family and village structures, they generate a "high-context" digital culture in which certain norms are considered self-evident. Moreover, the continuous broadcasting of replicable narratives and images reminds people of communal expectations. To inspire remittance flows among the transnational diaspora, the Facebook page users and village elders in the real world wield ' $a y b$ to get people to do the "right" thing.

\section{COMMUNITY NEEDS IN PALESTINIAN \\ REFUGEE CAMPS}

Before exploring how remittances are cultivated in digital spaces among Palestinian refugees, it is helpful to identify the increasing difficulties Palestinians face in accessing basic goods and services in Nahr al-Bared and other Palestinian refugee camps across Lebanon. A joint American University of Beirut-UNRWA survey report conducted in 2010 and 2015 found that 65 percent of Palestinian refugee households in Lebanon live at or below the level of poverty. The survey included 2,974 Palestinian refugee households in the country's twelve Palestinian refugee camps and areas adjacent to the camps. In northern Lebanon, where Nahr al-Bared is located, poverty rates increased by 11 percent between 2010 and 2015 (Chaaban et al. 2016).

The residents' condition is desperate because of their social, economic, and political exclusion from Lebanese society. Though Palestinians refugees have lived in Lebanon for more than seventy years, they are still considered foreigners under Lebanese law. This status deprives them of basic rights enjoyed by the Lebanese, such as the right to own property in Lebanon. They face restrictive employment measures, such as being banned from some liberal and syndicate professions (Chaaban et al 2016; Hajj 2016). Despite the August 2010 amendments to Article 59 of the Labour Law and Article 9 of the Social Security Law, which waived workpermit fees for Palestine refugees born in Lebanon, the majority of Palestinians in Lebanon are still underemployed, in illegal work arrangements, or unemployed. In fact, fewer than 3.3 percent of Palestinians have an official employment contract, witnessed by a public notary, that enables them to apply for a work permit (Chaaban et al. 2016).

UNRWA serves as the official primary provider of health, education, and welfare services in Palestinian refugee camps. But the increasing demands on UNRWA, resulting from the ongoing conflicts and community needs in Gaza and Syria, and the complete defunding of UNRWA by the Trump administration in 2018, have created a severe gap in services. The AUB-UNRWA study concludes, 
"Decaying infrastructure, a dearth of recreational spaces, insufficient access to roads, deteriorated water and sewage treatment systems, contaminated water, and jerry-rigged electrical wires along with open drainage ditches paint a gloomy picture of the camps" (Chaaban et al. 2016, 7). Indeed, the gloom is pervasive, and the gap between the needs of the community and provision of public goods and services by UNRWA and host states has widened since the report was published. In the presence of this humanitarian catastrophe, diaspora remittances provide essential resources and services.

\section{DIASPORA ECONOMIC REMITTANCES AND ICTS}

Extensive surveys and open-ended interviews reveal the power of ICTs in harnessing diaspora resources to support the welfare of refugees living in the camps. With the proliferation of ICTs anchored in ahl and hamula structures and traditional behavioral norms, Palestinians in the diaspora have been able to enter into the digital process of community building, reciprocity, and generating economic remittances.

One of the central failures of services in Palestinian refugee camps is the lack of accessible and affordable burial. The cost of washing and enshrouding bodies, two of the main components of the Muslim jana'iz (burial rites), are prohibitively expensive for many people in Nahr al-Bared, especially since host states, aid agencies, and nationalist parties provide no financial support for funerary rites. The jana'iz are a rather simple set of guidelines for burial (see Halevi 2007). The body is wrapped in a shroud, normally of plain white linen. Sometimes a green Islamic banner is draped over the coffin, but simple shrouds are usually preferred, both to defray costs and to emphasize the egalitarian nature of Islam. Many refugees can barely afford the shroud, the burial process, and the tradition of feeding mourners. These are essential components of a dignified burial, and the inability to provide them creates distress and embarrassment at a time when the family is already grieving. To explore how the Samoie community has attempted to solve these difficulties, I interviewed members of the diaspora who had commented on obituary posts on the community Facebook page. My interviews and data analysis suggest that Palestinians overcame the burial-cost dilemma by using the authority of pre-1948 village religious elders to activate patriarchal networks online.

After Nahr al-Bared was destroyed in 2007, the main cemetery and community burial washroom were rendered unusable. Though UNRWA rebuilt the homes of refugees, the community had to construct its own washroom and find additional cemetery space. In the short term, Sheikh Jihad, the revered religious elder in the camp, remedied the problem by asking well-to-do male family members from the same village as a deceased person in the camp to donate sums of money ranging from US $\$ 20$ to $\$ 50$ to pay for the washing of the body and provide shrouds for lower-income families (I-115L). As a longer-term solution, Sheikh Jihad set up an 
informal economic cooperative and engaged in fundraising with members of the diaspora (I-115L).

Sheik Jihad located piece of land for sale in the camp for roughly US $\$ 15,000-$ 20,000 and estimated the annual cost of running and maintaining the facility at around US $\$ 2,000$. He began an informal fundraising campaign by placing WhatsApp video and phone calls to village members from Nahr al-Bared living in the diaspora, using the power of the patrilineal ahl and hamula networks to encourage contributions. For example, as a member of Samoie village, he appealed to other Samoie members living in America, Canada, and Europe to contribute money (I-116L). Boosted by contributions from other villages and families in the diaspora, the campaign soon raised enough to cover the purchase of the property and several years' worth of operating costs. Sadly, Sheikh Jihad passed away in the spring of 2018 and never saw his dream realized.

His death sparked a flurry of Samoie Facebook posts that inspired further remittance flows. On May 12, 2018, six Facebook posts eulogized his passing; the next day, three posts engaged the community in reflection on Sheikh Jihad's humility and his service to the village and camp; and on May 14 and 15, three posts reminded the community of their duty to honor Sheikh Jihad. These posts were created by different Samoie villagers living around the globe. On May 20, another post remarked that the Sheikh was gone but would never be forgotten. The funds raised following Sheikh Jihad's death were sufficient to establish a shroud collective through which the community purchases shrouds and makes them freely available to any family that needs one, so that all families can afford a basic funeral for a loved one.

My intention in interviewing diaspora members involved in this online initiative was to understand how often individuals engaged in online activity, the content of their digital conversations with their camp "cousins," and what, if any, real-world actions this engagement inspired. A member of the diaspora living in Houston, Texas, described his frequent visits to his Facebook village page and his contribution to the fund for burial facilities: "I contributed to the cost of the washroom because it gives dignity to my family. One day my mother or father or brother will pass away, and this space will be available for them and for anyone else in the Nahr al-Bared community. We cannot turn our backs on our people, especially when it comes to offering them a proper burial. We must honor our family and village still left in the camp. It is our community's way. This is the moral thing to do" (I-126L).

Another member of the Samoie village diaspora living in Boston, Massachusetts, noted:

I am a fortunate one. I got out of the camp and I have a good life for myself in the United States. My cousins are struggling in Nahr al-Bared to make ends meet. My cousin, just my same age, suffered a miscarriage and a stillbirth. Had she lived in the West with better access to medical care like me, maybe her children would have 
lived. Both times I felt the family and village must embrace her and pay for their burial, even if we are far away physically. We must care for ourselves because no one else will help us. I paid for the washroom, in part, to keep women like my cousin supported, but also I feel more deeply to be a Palestinian woman connected to my roots ... even though I live far away in Boston. (I-129L)

Palestinian refugees in the diaspora actively engaged with the community online and felt empathetic identification with people living in the camps. They were motivated to support those in the camps because they could imagine themselves in the same position, struggling to care for a loved one who had recently passed away.

\section{PATTERNS OF GIFT EXCHANGE AMONG THE POOR: LESSONS FROM THE FLATS}

Palestinian patterns of reciprocity are reflective of gift-exchange patterns among other poor and marginalized communities. The poor, whether in industrial or nonindustrial economies, lack the ability to control their environment or to acquire a surplus of scarce goods (Stack 1974; Dalton 1961; Harris 1971; Lee 1969a; Sahlins 1965). Among the Black community studied by Carol Stack, goods in limited supply were perpetually redistributed through the community. She found that the "swapping" or exchange of resources among people living in the Flats created special bonds that initiated a social relationship and tacitly agreed-upon reciprocal obligations. Often times a member of the community would ask for a small item such as a piece of clothing or food to "test" whether another person would enter into the web of connections and obligations. Some members regularly offered goods and services to other people in the community, ranging from small items of clothing or food to more costly items or services like the use of a car or child care. Some of those involved in the exchanges were biological family; others became "like family" because of the exchange.

The exchange of goods among people in the Flats was not purely an "economic commodity transfer" but an instrument for what Claude Lévi-Strauss called "realities of another order" $(1969,54)$, like status, power, and connections within the community. Similarly, for Palestinians, the transfer of remittances is not just about giving money to someone in need but serves as a vehicle for affirming the giver's relationship to the recipients. It establishes the giver's identity as a Palestinian in the world at large as a Palestinian; it cements their role and status within the ahl and hamula framework regardless of whether they are blood kin; and it generates the potential for the community to reciprocate the gift by engaging with and supporting the giver in matters of everyday life, ranging from finding a marriage partner to conducting business in the camp. As my Boston interviewee observed, giving to the camp community made her feel she was "a Palestinian woman connected to my roots." Stack observes that the "folk model of reciprocity 
is characterized by recognized and urgent reciprocal dependencies and mutual needs" (1974, 43). This cooperative communal strategy is a "profoundly creative adaptation to poverty" for both Black and Palestinian refugee communities.

A member of Safad village who lives in Nahr al-Bared echoed the importance of transnational family and village connections in supporting a family during the burial process. In 2012, the refugee's father died of a stroke. He was born in Palestine in 1935 and migrated to Lebanon in 1948. After his death, the family moved to bury the body as quickly as possible, though they waited for family to arrive from Beirut, about two hours away. They buried him in the camp cemetery near his relatives. The refugee said: "Community members and the family from Safad village supported us emotionally. We were living in the temporary metallic shipping container homes [baraksat] waiting for our home to be rebuilt after the 2007 war. Our financial status was very bad, and we noticed that our neighbors from the baraksat and our extended village abroad played a key role in helping us pay for the funeral and offering us condolences" (I-105L).

Economic remittances help cover the cost of burial but also remind families inside the camp that members of the diaspora care for them still. The reciprocal exchanges between Palestinian diaspora and their kin in the camps offer a stability that is often lacking in the turbulent, unpredictable, and poverty-stricken conditions of refugee camps. Stack found that reciprocal kin-network exchanges in the Flats engendered a similar feeling of stability: "The collective expectations and obligations of poverty stricken kinsmen in the Flats result in a stability within the kin group, and the success of these networks depends upon this stability" $(1974,24)$.

One member of the diaspora underscored the financial and emotional stability that reciprocal exchanges offer the givers and recipients:

My father was born in Palestine in 1939 and migrated to Lebanon in 1948. He died of lung cancer in 2006 . He had worked his whole life in a meat factory to support our large family of three sons and four daughters. We faced many challenges in burying my dad. One problem was finding space to physically inter the body. We decided to bury him with the family, to save space and to keep him close to our hamula. He is buried on top of his uncle. We also had challenges affording the cost of the burial. But our family and our village from all over the world contributed to it. They care about us, and so we can handle life and death challenges. (I-102L)

A Samoie member living in Virginia further explained how mutual sacrifice and reciprocal exchanges maintained community stability and survival:

I get online most days and check-in with my family and village in the camps. I use our FB page. I am strongly inclined to support my family and village with money and resources. I am the eldest son of the patriarch of our family. I am highly educated and made it to the US because of my father's and village's sacrifices. I am one of the lucky ones who got out and really made a success of himself in America. It may 
sound like a humblebrag, but I live in a huge home in a well-regarded ZIP code, and I have an obligation to help those who stayed behind and could not get out. It is the right thing to do to honor my family and community there. They are my people and my family despite thirty-nine years apart. I strongly believe that the "haves" should help the "have nots." (I-114L)

The power of traditional social networks broadcast online is evidenced by their ability to inspire second- and third-generation members of the diaspora to send remittances, even if they have never lived in the camps and had to share their meager resources. This sentiment of self-sacrifice and the richness of reciprocity among communities living in poverty is beautifully expressed in Maya Angelou's I Know Why the Caged Bird Sings: "Although there was always generosity in the Negro neighborhood, it was indulged on pain and sacrifice. Whatever was given by Black people to other Blacks was most probably needed as desperately by the donor as by the receiver. A fact which made the giving or receiving a rich exchange" (Angelou 1969, 48). A woman from the Northeast United States who was studying for an advanced degree echoed this sentiment: "If I had the means, I would give a lot of money. My cousins in Zarqa [a refugee camp in Jordan] and Nahr al-Bared have always shown me kindness. I feel connected to them even though I have always lived in America. I know finding a job is difficult for many in the camps right now, so many people are in need of financial assistance. I have given about $\$ 20$ to $\$ 40$ a month, which is about all I can afford on my graduate student stipend. Sometimes I go without to make life better for others" (I-129L). Sending remittances despite her meager resources helped the community and affirmed her Palestinian connections.

Another third-generation Palestinian, who never lived in the camps and is currently settled in Canada, affirms this insight:

I do feel like I want and need to support my family and village financially. I give them what I can. Most Palestinians I know feel the same way. Those living in Palestine, the camps, and those living overseas are all at a great disadvantage as occupied and uprooted people; from a development perspective, this has significantly and negatively impacted their prosperity and caused them much "de-development," throwing many of them into a vicious cycle of perpetual poverty. I send money to help my people out. We take care of our own, that is who we are and who I am. (I-131L)

The replication of Palestinian village kinship connections and the frequent engagement of the diaspora in digital spaces have created a springboard for mobilizing diaspora remittances. The ready flow of remittances challenges the views of technology pessimists and development scholars who predict user apathy and remittance decay. These stories indicate that Palestinians have strategically melded pre-1948 kinship obligations and shared 'adat wa taqlid to meet the challenges of community building in catastrophe. This old strategy has been made new again with the power of ICTs. 
As I describe in chapter 2, during the Ottoman era and the British mandate period, patrilineal structures of kinship linked Palestinian villagers in real and imagined ways. These connections created the bedrock of community trust that underpinned political and economic transactions in the absence of a state or outside authority. In my early camp interviews, Palestinian refugees emphasized how these codes of behavior still anchor the norms governing interactions in the camps. Speaking of how the community could easily care for itself, the owner of a glass business in the Baqaa refugee camp explained, "There are strong religious and community values that are very traditional here. It makes protection an easy thing for us" (I-12J). Another said, "I trust in God and my neighbors to protect my home and business" (I-47L). A carpenter in Baqaa said, "I rarely encountered problems [stealing, expropriation] with my business in the camp because we have strong Palestinian values. It is shameful to your family if you do these things. Everyone would know your reputation was ruined if you behaved that way" (I-9J).

Though refugee camp interactions lacked a judicial system to enforce obligations, community rules emphasize values of collective honor, steadfastness, collective self-reliance, loyalty, and shame. They are easy to put into practice, even in a transitional space, because they require little physical infrastructure or planning: enforcement depends only on social policing and community vigilance. There are steep reputation costs for the family of anyone who engages in bad behavior that damages the property of others. A sheikh underscored the importance of a family's reputation inside the camps: "If one's family name was tarnished, it influenced the ability of people to marry well and conduct future business in the area. A bad event had implications for future generations in your family" (I-79L). A Palestinian working for UNRWA attested to the power of these unwritten rules: "If Nahr al-Bared camp were a Lebanese village, they would have much more crime. But they don't. They don't fight that much. It is because they have strong traditional values for protection" (I-5L).

Of course, as in any community, there are conflicts and petty crimes but, for the most part, camp residents reported feeling safe in their community because strong values of honor and shame anchor their communal behavior.

These values also promote cooperation. Extensive reciprocal exchanges are found among communities living in challenging conditions. Black communities in the United States, historically and legally marginalized and isolated from state structures, devised a social system in which strategic resources are distributed from a family base to a domestic group, and the reciprocal exchanges pervade the whole socioeconomic life of the community (Stack 1974, 38).

Still, a cynic might suggest that my interview evidence provides, at best, anecdotal support of the idea that those "angels" among us are always likely to help or give to others in need, and that they are the same people who are likely to log on to communal Facebook pages. The interviews highlighted above emphasize the effectiveness of communal values in shaping interactions only inside the camps; 
they do not address the issue of how these values influence behavior among members of the diaspora.

In chapter 1 I outline the central causal argument for reciprocity in digital spaces, based on the experimental work of Ernst Fehr and colleagues. They suggest that enforcement is dependent on the presence of a party with enough power or will to reward compliance and punish defection (Fehr, Fischbacher, and Gächter 2002; Fehr and Rockenbach 2003). Even in situations where selfishness would be very easy, because of fewer encounters and less observable action, reciprocity may occur if there is an "enforcer." Specifically, Fehr, Fischbacher, and Gächter (2002) consider how cooperative relationships arise even in contexts in which pure self-interest would cause a breakdown in reciprocity. A strong reciprocator, or an individual with a "pre-disposition to reward others for cooperative, norm-abiding behavior, and a propensity to impose sanctions on others for norm violations" can effectively motivate reciprocity and mobilize resources (Fehr and Rockenbach 2003).

Stack's ethnographic study of Black kinship and reciprocity in the Flats community underscores the importance of repeated, informal interactions in highcontext spaces. One of her respondents, Ruby Banks, asserts that someone who does not reciprocate will face communal sanctions: "Everything that goes around comes around in my book" (Stack 1974, 41). In other words, reciprocity is likely when there an individual, or an entire community, acting as an enforcer of culturally specific ideas of right or wrong behavior.

\section{THE AMISH EXAMPLE: SEPARATENESS, SHARED VALUES, FUNDING THE COLLECTIVE GOOD, AND SHUNNING}

The example of the Amish community in Lancaster County, Pennsylvania, intentionally living separate from state structures and enforcing their own behavioral norms, provides a powerful comparative case for understanding digital interactions and reciprocal exchanges in contemporary refugee conditions. Amish communal life, structured around the church and a tacitly understood Ordnung, or way of life, provides examples of easily replicable social norms, including the use of Meidung, or shunning, to mobilize resources and maintain community cohesion.

The Amish faith emerged in Switzerland in 1693. The Amish split from the Anabaptist community as the result of a disagreement over the use and practice of shunning. Anabaptists excluded wayward members of the community from holy communion but did not ostracize them socially. The Amish faith's founder, Jakob Amman, felt that expelled or shunned members should not only be banned from communion but also shunned in daily life (Kraybill and Bowman 2002).

The enforcement of shared values is important because the Amish community purposely separates itself from the outside, "modern" world, eschewing many modern technologies, and emphasizes community self-reliance. In order "to stay 
whole, or to preserve their snug community," the Amish have crafted a distinctive set of structures, traditions, networks, and rituals that "have been invested in the social bank, so to speak, and can be mobilized to serve the entire well-being of the community and individuals as well" (Kraybill and Bowman 2002, 20). Communal life is organized around three basic social units: the settlement, the district, and the affiliation. Unlike the Palestinian ahl and hamula units of organization, these units are explicitly associated with religious faith.

The settlement is a common geographic area that encompasses anywhere from dozens to thousands of Amish people. A district is a congregation or church organizational unit made up of twenty-five to thirty-five families. The affiliation is a cluster of congregations or districts that are in spiritual fellowship (Kraybill and Bowman 2002, 13-14). These social units share a base of knowledge and accepted values, norms, beliefs, and obligations that "help motivate and inspire individuals to act on behalf of their fellow members and community" (Kraybill and Bowman 2002, 20).

Amish norms of behavior are embodied in the Ordnung. According to one Amish man, "The order is not written down. The people just know it, that's all." Through actions and stories, this way of living becomes ingrained, such that it is "taken for granted as reality in a child's mind" (Kraybill and Bowman 2002, 112). For example, when a child is born in an Amish home, several adult women come to assist the new mother and care for the baby for a while. Within two or three days of a barn fire, the community erects a new barn. "This gigantic task happens ritualistically, seemingly almost without effort" or formal structures to organize and pay for the barn. Behavioral norms stipulating that one should "yield to the needs of the community above one's own generate an abundant supply of capital that serves the common good" (Kraybill and Bowman 2002, 21). This happens spontaneously because it is a habit of communal orientation and woven into the texture of daily life (Kraybill and Bowman 2002, 143).

Though the overwhelming majority of Amish uphold the Ordnung, there are still "wayward" members who challenge community values, usually by adopting technologies that put their own interest ahead of the community's and eschewing "nearness" (Kraybill and Bowman 2002). In cases where ritual confession or gentle nudges are insufficient to guide an individual toward choosing a better path that is in line with Gelassenheit, or submission to God's will, the community resorts to Meidung, or shunning. The ban from religious and daily communal life "is the ultimate form of social control" and the "teeth" of Amish discipline (Kraybill and Bowman 2002, 21). Shunning or shame is an exceptionally powerful tool for social control in the absence of formal state structures. One Amish person facing Meidung described what it felt like. "You suddenly lose all your security, and you become a goat, like a piece of dirt" (Kraybill and Bowman 2002, 114) It is the cornerstone of Amish reciprocity because it gives credibility to the system and helps ensure resource mobilization. 
THE POWER OF SHAME IN DIGITAL SPACES

Kraybill and Bowman's study of Amish life explicitly rejects the notion that a similar sense of spontaneous communal caring, providing a collective pool of resources and supporting the well-being of the community and its members, can arise in cyberspace. They authors consider cyberspace to be "context free," whereas Amish people interact with others in a "high context" culture. They know more than just another person's avatar, name, or email address: they know their parents and grandparents, their church district, ministers, their occupation and hobbies, and their status in the community, as well as their temperament. They operate within a deeply embedded, highly contextualized set of relationships that are "quite different from the multitude of transitory ties in modern society and cyber space" (Kraybill and Bowman 2002, 150-51). Yet Palestinians effectively elicit reciprocity online, in the form of remittance flows, precisely because they have created a high-context digital space with easily replicable norms of loyalty and collectivism, rooted in the ahl and hamula and strategically enforced by means of ayb. Just as an Amish person knows the Ordnung because it has been ingrained in their daily life, Palestinians know the value of honor, loyalty, steadfastness, shame, and collectivism in digital spaces because these principles are constantly replayed in digital life and reinforced at home.

Extending the power of shame to digital spaces is a tricky endeavor because, in the view of scholars like Kraybill, the digital space provides anonymity and a sort of disembodied "utopia" where one's real-world positionality does not matter. Much of the early technology-optimist literature suggested that the internet would be a liberatory space, especially for women and communities in repressive Arab states. For example, writing in 2005, Fereshteh Nouraie-Simone saw cyberspace as a virtual "room of one's own" in which women would be able to transcend repressed social identities (61-62). Musa Shteiwi wrote that the internet's focus on the individual rendered "traditional social control mechanisms of [women's] behavior useless" $(2003,489)$, and Masserat Amir-Ebrahimi compares blogging to a "virtual unveiling" (2008, 90).

However, cyberspace cannot be seen as what Jesse Daniels (2009) terms "a liberation utopia of disembodiment" $(102,110)$. Real-world hierarchies are not suspended online, and experience has proved that the internet is not a safe space for marginalized people. ${ }^{1}$ Of course, a person's identity is never fully secret in digital spaces, but the illusion of anonymity may generate some very bad behavior. Online interactions exhibit a lot of the negative aspects of transitory encounters, like cyberbullying and "throwing shade" with remarks that people would be less likely to utter in public life.

Kraybill and Bowman (2002) note that the Amish strategically engage with technologies in ways that cultivate nearness and community cohesion. In much the same way, Palestinians interact with ICTs in a way that cultivates nearness and 
community in their perpetual state of dispossession. Because these digital spaces are patterned on pre-1948 ahl and hamula identities, users know other people's full social context dating back to pre-Nakba times, including family lineage and reputation. There is no anonymity on an ahl-hamula Facebook page.

A young Palestinian woman who has grown up in the United States and lives in Portland, Oregon, eloquently shares how it feels to interact with Samoie villagers online and in real life:

Though I live in America and grew up here, I live in a world within a world. I am a nineteen-year-old American college student on the surface, but that is just what others see. I am actually a daughter of a family that comes from Samoie village, and my entire understanding of my identity, what I stand for, and who I am connected to and associate with today is rooted in a village I have never been to except for through my father and mother's memories. The Palestinian village and all the associated gossip and the business-like who is marrying who, and who has a new job, and who has money or doesn't-of village life persists today for me. Whether I am online engaging in social justice activism or whether I am visiting my parents and having dinner, I am fully aware of expectations of who I am, what I stand for, and what everyone else that matters in this world expects of me. There is no escaping that, despite the physical distance from Palestine and much of my kin. (I-130L)

One Samoie villager who grew up in a camp in Lebanon but now lives in Houston, Texas, said:

Even on the Facebook group page, we share the collective trauma of the Nakba and the continued dispossession of our people from our ancestral homeland. 1948 might feel like a time long gone for many people, but for people from Samoie village like me, well, you see, we are reminded every single moment and every day of our collective suffering when we see Zionist occupiers destroying our people and land. This makes me and my children remember our connection and obligation to our community. I want to take on the suffering of the suffering people in the camps. I can never do it completely, but I want to ease the pain and make their life a little better by giving money to pay for their medical fees, education, or food. We have a shared special tie with our relatives even in a digital space. There is an obligation to support them because of our community ties and shared trauma. (I-120L)

One man who grew up in the camps but has children who have only ever known life in America observed:

My children have never experienced the suffering of being hungry and feeling poor. When they were young children, I would take them on trips to Nahr al-Bared and Rashidieh camps, where we have family. I would take them to the poorest relatives, not to make them feel superior or like wealthy people are better than the poor. I was trying to show them humility, compassion, and empathy for those that are our blood connection but need help. I would give them money to dole out to family and friends in the camps. They got to experience what giving feels like as children. Now that they 
are older and married themselves, they have the habit of giving to family. When a story pops up on the Samoie [Facebook] page, they don't even question the necessity of sending money to help. It is an ingrained behavior for them. (I-127L)

A third-generation Palestinian from Samoie village living in Texas said:

Everything in our life is structured around our family and extends to the village. My parents are from neighboring pre-1948 villages and grew up in Lebanon, then came to America in the 1980s. Even in Houston, our Palestinian roots are strong. At home, Baba and Mama talk about the importance of caring for those in the [refugee] camp. And online, I see it all over Facebook on the village page too, that we are supposed to take care of each other because no one else will. Everyone on there is related to me-we are all like cousins. The main thing to know from all these interactions is: family and village come first, always. (I-126L)

These comments show that digital relationships on line are full bodied, high context, and lifelong. A high-context digital space enables strong reciprocators to enforce communal norms just as they did in face-to-face interactions in the villages and refugee camps. In such a digital space, 'ayb is as powerful a force as Meidung in Amish settlements.

The community obligations of sending remittances and protecting the vulnerable are reinforced by patrilineal kinship ties. These obligations are informal and unspoken because, as Amos Nadan observes, a need for signed agreements between community members "would be regarded as shame or 'ayb" $(2006,196)$. The power of shame in communities means that informal tools may suffice to enforce good behavior, punish defectors and shirkers, and ensure the continuation of remittance flows. One man said:

I was a lucky one that made it out. My entire family sacrificed so I could be the one to make it. My sisters did not get to go to school, even though they were brilliant, because we could only afford one tuition. We all nearly starved in the early years so that I could go to school. I weighed barely one hundred pounds when I started college as a seventeen-year-old. When I got my first full-time paying job as an engineer in Saudi Arabia, I sent almost 70 percent of my income back to my family. I felt it was my honor and duty-no, even more than that, it was my moral obligation to help my entire family and village by giving them money from my paycheck. It would be 'ayb, shameful, to turn my back on them. Of course, I help fund whatever is needed, like the most recent shroud cooperative and burial washroom. I also send many young kids to college by paying their tuition for medical school or engineering. I make them send me report cards before I wire the money. (I-123L)

Though asking for proof of a report card may seem as though the sender does not fully trust the recipient of the money; I think this reciprocal exchange highlights what Mauss (1954) believed to be implicit in every single "gift." The gift recipient may not be able to return a gift in kind to the giver, but presenting the giver with a report card indicates an awareness of upholding one's communal obligation to 
be a good student, to show it through grades that the student proudly displays, to represent the village well in the school setting, and to one day do well enough in a career that they can maybe "pay it forward" to the next generation. When pressed to explain how shame played out in the community, a Palestinian echoed the description of Meidung experienced by Kraybill's Amish interlocutor.

My entire being is wrapped into this community. If I acted poorly, like not sending money ... oh, I would hear about it, even though I lived in America and didn't plan to return to the camp. Let me tell you a real example. I mean, the fact that I am sharing this with you shows how far the rumor and bad talk about this person has pervaded the community. There is a respected man in the camp, he has a successful business. He traveled abroad during the early 1970s and made lots of money. All of this is great, right? Well, the shame in the whole story is that he is so filthy rich, owns a bunch of companies, and lives in Amman, Jordan, now but doesn't give back to the village in the camp at all. I hear he has fancy cars and wears designer-label clothing. He has been divorced a couple of times and he ended up marrying a Jordanian woman because no Palestinian family or woman would take him, because he also has never sent a single penny back to the camps. Can you imagine wearing a designer suit while your family in a refugee camp suffers? It is so disgusting. Even his own brother and sons are embarrassed and ashamed of him. They deny their connection to him and talk bad about him. He is a dirty stain on the family name. They must deny the connection, or no one would ever do business or marry into their family, because he is not a person that takes care of his people. He denies his family and roots and crossed a line no one should cross. (I-120L)

On the basis of the rumors about this man's behavior, the community shuns him and anyone who willingly associates with him. Shirking community responsibilities carries financial costs as well as reputational costs because of others' reluctance to do business or marry into a family with a perceived shirker or defector.

A recent online marriage match highlighted the importance of reputation for a hopeful groom. A Palestinian woman connected with a Palestinian American man through their village's Facebook page. Brief written exchanges online led to a series of WhatsApp calls and eventually a FaceTime meeting. When he mentioned marriage, the woman expressed interest but noted that her brothers would have to research his behavior and reputation before permitting the marriage. I asked the brothers about how they did this. One told me:

I want my sister to marry a man who takes carry of his family first, and the best way to know if this is going to be true is to ask his family in the camps if he sends money to them or gives them gifts. If he is a selfish American guy, he would just keep the money to himself and deny his family left in the camps. My sister deserves a man who will respect his family and our traditions. I learned that the guy, who we are distantly related to, does send money to his sisters and regularly helps out. I talked to his entire extended family to confirm the truth. He has not visited the camps in a long time, but he sends money. His honorable behavior meant we would support their engagement and marital contract. (I-128L) 


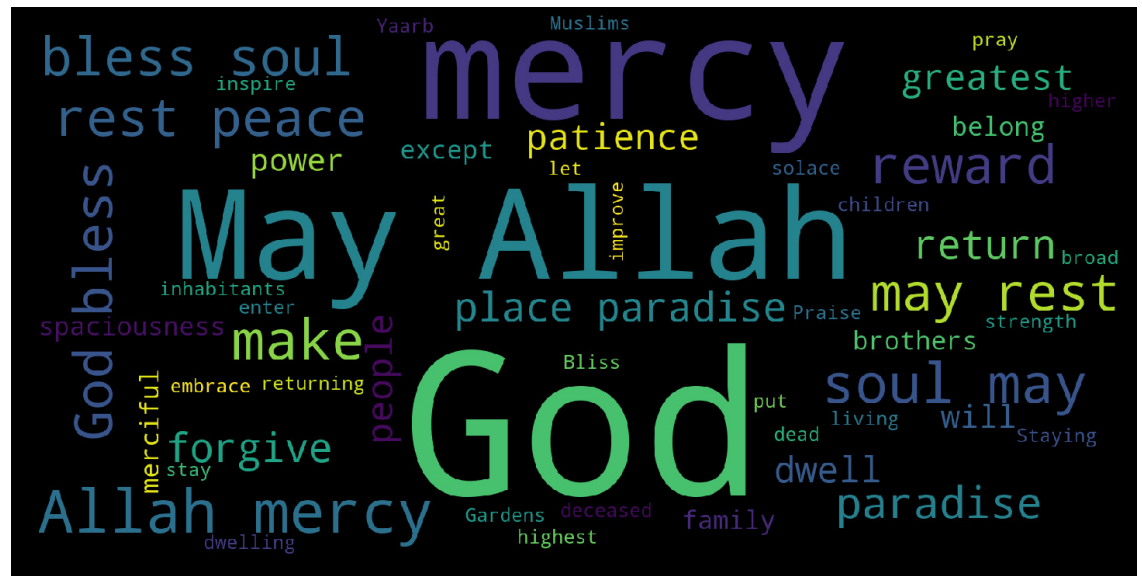

FIGURE 6. Word cloud of the most common words appearing on Samoie village Facebook page, May 2017-May 2018.

Though the man had lived in America for more than twenty years, his reputation for regularly sending remittances back to the camps made him a suitable partner for a woman from a respected family. I asked another of the woman's brothers what would have happened if they had learned that the hopeful groom was not a reciprocator. "Well, there would be no more talking between the two of them online," he responded. "It would mean maa'-salaami, or goodbye!" In sum, not contributing to the community incurs practical material costs that serve as a powerful incentive for reciprocity.

Yet another interviewee said, "It is because we have strong traditional values for community self- protection that we can get remittances today from our family and village living abroad" (I-115L).

A culture of shaming was evident in frequent passive-aggressive digital posts that criticized members of the diaspora community when they were not sufficiently responsive to calls for sending money or supporting the camp. A large number of posts on the Samoie Facebook page are religious in nature. Initially, it seemed that this indicated the deep religiosity of the community. Examination of a "word cloud" highlighting the top words on the Facebook page emphasized mercy, God, Allah, blessing, charity, virtues, and a variety of Islamic religious terms (see figure 6). However, interviews revealed that these religious posts often had a subtext. One particular user from Nahr al-Bared (referred to below as X) often posted images of the community cemetery littered with trash. He also shared images of old people sitting abandoned in wheelchairs in the camp and cracked or broken tombstones. He sometimes typed below the pictures, "Who among us cares for our community?" and added a separate post of a Qur'anic verse about the duty of the wealthy to serve the poor, such as "And as for those who strive in Our path-We 
will surely guide them in Our ways. And Indeed, Allah is with those who are of service to others" (29:70). Another post quoted the verse "Indeed, Allah is with those who are righteous and those who do good" (16:129).

His shaming posts struck a nerve among a digital community well versed in expectations of loyalty and collectivism. A deeply religious member of the Samoie diaspora in North America responded by linking his giving to his family and religious upbringing: "It is my shared connection and obligation to my village to send money to help those in the camps. Beyond my familial ties, my Muslim faith makes it incumbent for me to give zakat, or tithing. This is one of the five basic pillars of Islam, to give to those in need. So of course for me, there is no question that a percentage of my income must go to those in the camps that need help" (I-12oL).

In the high-context space of the village Facebook page, these posts had powerful implications for the diaspora audience. One said:

Oh man, every time $\mathrm{X}$ posts his religious verses and these horrible pictures of my family's broken gravestones or old people languishing in wheelchairs in a crappy alley, I feel so guilty and ashamed. Sometimes it is like he is directly aiming the posts at me. He will post a picture that includes an image of my grandfather's grave. I really know it is directed at me. Sometimes I felt like he knew what I was doing on the other side of the screen [chuckling, laughing], because I would be shopping online at Amazon for some random thing I didn't need and then quickly empty my digital cart and wire one or two hundred bucks via Western Union or send some money in the suitcase of a relative heading to the Middle East to give to people in the camp. I have to give money to feel okay about myself and my family. I haven't ever lived in the camps, but I know what I am supposed to do. You get treated like shit if you do not give when the community needs it. It is a good reminder to not be a selfish jerk. I know they are right too, in my heart. (I-128L)

Another second-generation Samoie villager, who grew up internationally, described how conversations with her father, who grew up in Palestine and the camp, shamed her into giving money.

My Baba doesn't use Facebook, but every now and then I would bring up something I saw on the Samoie page. When the young kid got burned at the end of last month [May 2019], I felt so awful. I called up Baba and asked him, "Are we related to that boy?" He affirmed the connection. He told a story from Palestine of how he was playmates with the grandfather of the child. He said that they really needed the money and how it would make such a difference to their family and our village. He also emphasized how much it would mean to him if he could say I gave money too. He would feel very proud to say his daughter cared for those in the camp. He added, "You have so much, what is a few hundred dollars to you? Nothing. It is shameful to not give something that would mean so much to them and costs so little of you." So I felt a lot of pressure to do the right thing, and I didn't want to make my Baba feel ashamed of me. It is really weird, you know? I mean, it is odd how the Facebook page and my Baba's words interact to make me give money. It is the right thing to do, even if there is a selfish part of me that wouldn't give without some of that pressure. (I-124L) 


\section{THE DARK SIDE OF SHAMING}

Though interviews and surveys from Samoie villagers evidence that shame is an effective tool for enforcing reciprocity in digital spaces, it also has a dark side. Any person who identifies with or behaves in a way that deviates from the patriarchal village structure and behavioral norms may be ostracized, or worse. Women who divorce or choose nontraditional career pathways and queer communities suffer from the rigid understandings of honor, loyalty, collectivism, and steadfastness in the Palestinian community. Rather than bringing people together, shame may be used to tear apart individuals and their families and villages. Furthermore, this alienation may erase the patterns and obligations of reciprocal exchanges necessary for community survival.

Brené Brown discusses shame as a "silent epidemic: associated with depression, grief, anxiety, eating disorders, addiction, and violence." She defines shame as the intensely painful feeling or experience of believing we are flawed and therefore unworthy of acceptance and belonging. Women and nonheteronormative individuals often experience shame when they are entangled in a web of layered, conflicting, and competing community expectations. Brown finds that shame "creates feelings of fear, blame, and disconnect" $(2007,29)$. Even women who do not follow the established and expected life pathways of marriage and children face isolation and pressure to conform or risk being sidelined in family and community interactions.

Louise Cainkar's research on Palestinian women in Chicago demonstrates the downsides of patriarchal norms for community members, even those living far away from the camps, who choose nonendogamous marriage partners, divorce, or follow nontraditional career paths. She found that Palestinian women's attachment to families and patriarchal practice allowed families to continue exercising traditional patriarchal notions about women even after immigration to Chicago. In particular, "In a community like the Palestinian, where maintaining traditional culture is politically extremely important due to statelessness, occupation, and diaspora and because this work of course must primarily be done in the home or in the confines of the community, women are under more pressure than men to be traditional and maintain traditional roles. Consequently, gender and politics interact to place a double burden of tradition keeping on Palestinian women" (Cainkar 1994, 88).

This "double burden" was especially visible in marital matches. Marriage of a Palestinian Muslim woman to a non-Arab, especially a non-Muslim, was deeply frowned upon by the entire Palestinian community, regardless of social class. These attitudes remain prevalent today. Of the fifty young men and women I surveyed between the ages of 18 and 30 living in the camps and in the diaspora, 80 percent felt that the "old ways" of being a Palestinian in the world persisted despite the influx of new ideas and experiences in the West. Most of the young people I 
interviewed who married during the six-year survey period stayed within their kinship framework. The remaining 20 percent represent a significant departure from traditional norms.

Though Palestinian political elites often adopt a rigid attitude toward different identities and groups, local ahl and hamula interactions, especially among digitally connected youth, suggest that Palestinian notions of what is honorable and shameful are potentially quite malleable. One young survey respondent wrote:

Palestinians raised in the West are inevitability going to have a different twist on many issues, though young people in the camps feel pretty similar to me the more we interact online. For example, we are used to the idea of dating and premarital relations-there is a difference in finding marriage for us than how our parents and grandparents did it. It shifts away from how we normally do things as Palestinians. We are more focused on love matches than on bridging family relationships through intrafamily marriages. Finding love for ourselves is most important, not family honor. I don't know, maybe finding love is a part of honor too. (S-49)

Another young woman wrote in her survey response:

I am currently working on a $\mathrm{PhD}$ in science, have no plans to get married ever, and am an open atheist. Many of these ideas go against core values in my Palestinian family and village. My Palestinian uncles/aunts and I have argued about the importance of education for women and the role of women in the home in the past. My Palestinian relatives in the U.S. know that I am living with my partner and that we are not engaged. These ideas are different because many of my aunts and uncles do not believe education is as important for their daughters as it is for their sons and have actively barred their daughters from going to college or school. My extended family also stresses the importance of marriage and having children for women in their 20's constantly, whereas I encourage my cousins to wait for those things until they are older. (S-26)

In her oral response to the survey, she continued: "I think my ideas about female education are catching on in the extended Palestinian community-heck, my cousin just became the first female medical doctor from our family in the campbut I don't think my ideas about marriage are going to catch on any time soon, as never getting married but having a loving partner is a pretty radical viewpoint, even for people my age in the US" (S-26).

Women who deviate from prescribed social norms are socially ostracized. One of my survey respondents shared the social loneliness and humiliation she faced during her divorce from an American man and the unexpected ways in which real-world and digital shame collided.

When I went through my divorce in America, my uncles in the camp were terribly ashamed that I would speak about it publicly and that I posted my status change from "married" to "single" on my Facebook page. The family patriarch, my uncle, called me from Nahr al-Bared and told me I would go to hell for abandoning my marital 
vows. I explained to my uncle that my ex-husband had cheated on me and showed no remorse. He left me. My uncle did not care. He also smugly said, "That is what you get for marrying an American guy for 'love' and not a Palestinian man from the village for family honor." So that was how the old guard spoke about divorce. I was terribly distraught. But in other conversations with young people from the village online, the talk and feeling was different. I am very close to my second cousin, A. We were playmates when I went to the Middle East in the summers as a child. During my divorce, he and I chatted daily online and occasionally on WhatsApp calls. Anyways, A married a non-Palestinian woman he met in college for love, so we often talked about marrying for love and not for the family's traditions. He was proud of me for holding my head high during the divorce and he said he would never have stuck around if he had been in my shoes. The younger generation doesn't think of divorce like our parents do. We think there is more to life than just keeping up some image of a perfect marriage for the purpose of preserving the family's honor in the community. Our personal welfare sometimes is more important than the family's reputation. (I-111L)

In her account, village elders reinforced rigid codes of honor and isolated her with shame. However, in an online conversation, a cousin conveyed to her a new message of Palestinian respectability, dignity, honor, and steadfastness: in the face of a Western man's betrayal of vows, she was a strong Palestinian woman who held her head high and pushed on. As Walaa Alqaisiya astutely asserts in her study of queer Palestinians, "On the one hand, performativity explains how social norms emerge from a repetition and reiteration of certain acts, which (re)produce dominant power structures. On the other hand, it identifies how potentialities and possibilities for re-signification of those dominant norms lie within their performative repetition $(2018,38)$."

In effect, honor and steadfastness can be performed in different ways by Palestinians, and digital spaces give room for this subversion of shame. As Judith Butler suggests, "Possibilities of gender transformation are to be found precisely in the arbitrary relation between such acts, in the possibility of a failure to repeat in 'proper' terms the gendered identity ascribed to us $(1999,179)$."

The cost of shame is also evident members of the Palestinian community who identify as queer. Queer communities are often slurred by being erroneously cast as collaborators with Israel and dishonorable to the Palestinian cause. Alliances among Israeli and Palestinian queer communities are widely viewed with suspicion. Political organizations like the PLO and Hamas explicitly reject the LQBTQA+ community and engage in targeted homophobic harassment (Alqaisiya 2018; Ashtan 2020; Schotten 2018). However, engaging with Palestinian homophobia is tricky because, as Heike Schotten (2018) observes, criticism of Palestinian political elites and their institutions, and society more generally, often invites policy elites, humanitarian groups, and Western activists to proclaim the orientalist adage that "the natives don't know what is good for them" and to represent Israel's "democracy" as exemplary in its embrace of the queer community. 
Palestinians, and queer Palestinians specifically, challenge orientalist worldviews because they do not disappear "as they ought to" (Said 1978). Schotten maintains that queer Palestinians "constitute a form of dissidence by their very existence" and observes that Said's characterization of Palestinians as troublesome resonates with queer theory's "defiant attachment to all those who are not or cannot be made assimilable. Indeed, the inassimilable is in some sense who and what queer names-that illimitable list of deviant others whose existence destabilizes, disrupts, or thwarts the otherwise smooth functioning of institutionalized, hegemonic regimes of normalizing, heteronormative power" (2018, 15-16).

Palestinian queer communities, embodied by groups like alQaws (whose name is an abbreviation of "rainbow" in Arabic), challenge the norms of both colonialist state-building projects and nationalist ideas rooted in patriarchy (Alqaisiya 2018, 38). Interestingly, alQaws has strategically avoided collusion with Israeli pride groups without affirming restrictive Palestinian patriarchal notions of honor and shame. For example, Palestinian Queers for Boycott, Divestment, and Sanctions (PQBDS) played a pivotal role in the campaign for economic protests against Israeli settlements and reoriented local civil society's understanding of the queer Palestinian subject as an honorable resister of Israel's occupation and a champion of Palestine through much of its digital activism(Ashtan 2020).

It is easy to see how shame has been used to ostracize and alienate these communities and undermine connectedness among all kinds of Palestinians such that reciprocity is eroded. I do not intend to offer an overly optimistic vision of the full embrace of the queer community by transnational Palestinian villagers; but I think we may underestimate the compassion and transformative resilience of the ahl and hamula networks.

In his poignant introduction to Queer Palestine and the Empire of Critique, Sa'ed Ashtan shares the story of coming out to his ahl in the Occupied Territories. When he came out to a close Palestinian Christian friend, he was shamed and rejected. But when he came out to his mother, she embraced him and said, "The reason that I am crying is that I cannot believe you have gone through all of this without me. I wish that I had been able to be by your side. But I am now comforted that you have come to me... This is something incredibly difficult in our society, but you are my son. I love you, forever and always" (Ashtan 2020, introduction).

Ashtan also recounts how his cousin introduced him to another man, a potential romantic partner, without comment about his sexuality, as if it were normal in Palestinian society. He finds it amusing that his Palestinian family still wanted to play an active role in matchmaking, even in queer romantic relationships. Although anecdotal, these stories indicate the hope and potential for a more expansive and inclusive set of Palestinian norms and a revised understanding of what constitutes shameful behavior in families and villages. As I suggest in chapter 4, digital spaces offer an opportunity for the Palestinian community to remake its understanding of itself, its political vision, and how it operates in the world. 


\section{CONCLUSION}

The strategy of turning toward the pre-1948 village and family unit to connect with the diaspora network in digital spaces has encouraged members of the diaspora to send remittances to partially solve the protection-gap dilemma for refugees in the camps. This strategy is reinforced and strengthened by village and family ties. The ability to mobilize digital connections to raise funds for facilities like the communal burial washroom and shroud collective is astounding given the protracted nature of the Palestinian refugee conflict and the geographic distance separating Palestinians living in the camps from those in the diaspora.

Nahr al-Bared's respected religious elder, Sheikh Jihad, was careful to note in interviews that though certain families or villages might have donated more than others to the fund for burial facilities, his intention was to make the resources accessible to all the families and villages in the camp, regardless of place of origin, income, or status (I-116L). He emphasized, "We take care of all our people, even in death" (I-115L).

Collective undertakings like this mirror Prerna Singh's insights on the role of group identity in fostering collective welfare (2015a, 506). In her study of Indian subnational identity, she finds that attachment to a subnational rather than a national identity encourages positive actions, like redistributing collective goods. She contends that subnational group identity, commonly thought of as exclusionary, insular, "tribal," and chauvinistic, might be reframed as a shared identity that could produce better lived experiences for the entire community.

Contrary to the views of technology pessimists, representation of the ahl and hamula in Palestinian digital spaces, along with easily replicable and enforceable norms of honor, loyalty, and shame has generated extensive remittance flows from the diaspora. The financing of collective welfare projects signals both the nearness and capacity of the community. Encouraging remittance flows depends to some measure on the power of ayb, or shame. Although this can be damaging to individuals who identify or act in nontraditional ways, there is some evidence that notions of shame are malleable. 


\section{4 \\ Social Remittances and the Disruption of Traditional Norms and Community Leaders}

In chapter 3, I show how, in the face of critical shortages of basic public goods, refugees use digital spaces to reaffirm kinship (and kin-like) ties, reinforce Palestinian ahl and hamula 'adat wa taqlid, and inspire remittance flows from the diaspora. But while they may reinforce traditional social norms, ICTs also hold the potential to alter and undercut the very networks that they facilitate (Ramo 2016). ICTs may empower new actors, propel communities to redefine themselves, and undermine social norms. In fact, ICTs used by Palestinian refugees may generate a new space for dialogue that inspire what Peggy Levitt $(1998,2001)$ refers to as social remittances, or the flow of new ideas, values, and behaviors between and among diaspora and camp communities.

To borrow from Mohsin Hamid's observations in his magical-realist novel Exit West, ICTs allow for conversations that "might have never been and could never be" in the "real" world. It is unlikely that Palestinians living in isolated camps in the preinternet era would have been able to communicate in real time with those in the diaspora. Moreover, the wide availability of smartphones in the camps allows the younger generations of Palestinians to have discussions about their communal identity and expected norms out of earshot of traditional authority figures like religious elders or family patriarchs. Palestinians in the camps and those in the diaspora can debate, sometimes heatedly, taboo topics and reimagine the Palestinian community in a space that did not exist before the Internet. ICTs serve as a mechanism for the dynamic evolution of the village and family identity to reflect the new political challenges and opportunities confronting those inside the camp and in the diaspora. 
One Palestinian from the diaspora shared reflections from her 2017 diary on the new connections and ideas that digital interactions introduce.

The first time I "met" a Palestinian woman whose family had never left Jerusalem, who had lived there since long before 1948, was in an online digital chat room. She was talking about the challenges of traveling for her humanitarian work. I asked her how she was able to travel from Jerusalem to London as a Palestinian woman in 2017. She said, "Oh, because I have an Israeli passport. I get treated like shit at the airports and checkpoints, but still I can travel." She said, "What about you?" I said, "I am a documented refugee with UNRWA but also have an American passport and live in the US, so that is how I travel." She said, "Oh, so your family left in 1948?" I said, "Oh, yes." I felt shame that we had left and she had stayed. I don't know what she thought of me, of all of us who left and ended up in the camps. We acted kind of like distant cousins, unsure of how intimate we could be-her experience was so different than mine and my family. We felt so differently about many issues-one state or two states? She wanted one state, and I wasn't entirely convinced it would be the best for us. She felt all Palestinians could return to their old villages, that there was space, but I felt it was a pipe dream. Her Palestinian state was so different than the Palestinian state I envisioned. We were operating in two different worlds with two very different ideas about what our nation and state would look like. I felt I could not speak about this separateness to my family and to my village in the camps in Lebanon because it meant we were not, in fact, one with the Palestinians living over there [in the Occupied Territories]. We had been divided by history and time and real experience. I couldn't help but feel that those of us from the camps in Lebanon and Jordan and Syria and living in all the nooks and crannies of the rest of the world ... that we were building a distinct dream.

Her diary exposes the complexity of Palestinian identity. It also shows how the internet presents an opportunity to examine the shared norms and ideas that breed reciprocity and remittance flows, and at times, disrupt those connections among Palestinians living in different spaces. Levitt's $(1998,2001)$ study of the transnational diaspora from Miraflores, a village in the Dominican Republic, provides a helpful comparative case for making sense of the dynamic among transnational Palestinian refugees. To explore this tension, I used survey data from the Palestinian diaspora spanning the second, third, and fourth generations in Australia, North America, Europe, and the Arab Gulf states.

The data show that in addition to generating vital economic remittances, digital spaces introduce social remittances that create an altered sense of Palestinian political identity. The flow of social remittances in digital spaces generates controversies over communal gatekeeping and enforcement of norms. Engagement with digital technology changes the users of the technology and introduces unforeseen issues. When real-world norms bump against digital practices, the conflict may disrupt accepted modes of engaging with the community, especially with village and family elders. In one particular case, the enforcement of norms in the digital versus real world sparked a village conflict that threatened to undermine the flow of financial remittances. 


\section{UNDERSTANDING SOCIAL REMITTANCES}

Though the transnational migration literature focuses heavily on the flow of economic remittances, people also send and receive social remittances-ideas, behaviors, and values that flow across borders among transnational communities (Levitt 1998, 2001). Social remittances can help individuals embedded in a particular context and accustomed to a particular set of identities to imagine a new cartography with which to navigate the world (Appadurai 1990). For example, they can encourage people to try on new gender roles, experiment with new ideas about politics or religion, and adopt new forms of organization (Levitt 1998, 2001). Notably, Peggy Levitt and Deepak Lamba-Nieves (2010) argue that social remittances have a circular effect: the ideas and experiences that migrants bring from their country of origin strongly influence who and what they are exposed to in the country where they settle. In turn, these experiences affect the social remittances they send home. In Transnational Villagers (2001), Levitt traces the flow of social remittances from migrants living in the Jamaica Plains neighborhood of Boston, Massachusetts, to their home community of Miraflores in the Dominican Republic. She finds that social remittances have complex effects on transnational village networks.

It is important to unpack how social remittances work before extending the concept to Palestinian refugee communities interacting in digital spaces. Among Miraflorenos in both the sending and receiving countries, Levitt shows, social remittances have encouraged transnational cooperation and revitalized the way in which the community views itself. Traditional kinship connections have been reconfigured to meet the challenges of contemporary spaces. Specifically, Levitt finds that Dominican political parties like the Partido Revolucionario Dominicano (PRD) intentionally pattern themselves on the transnational family and village networks of Miraflorenos. The PRD operates via circulos de influencia, or "influence circles," of family members in the Dominican Republic and the United States, whom they call upon to make donations or attend party events. In effect, "non-Dominican citizens" like the migrants living in the Boston suburbs "are part of the party" (Levitt 2001, 137).

New ideas of how to connect with bureaucracy and influence political outcomes, based on experiences in the United States, have influenced people living in Miraflores, their connection to the PRD, and their views of local governance. About 50 percent of interviewees felt that the exchange of these new ideas between migrants and villagers at "home" on the island had had a positive net effect on sustained community connection and reciprocity, evidenced in financial flows to Dominican political and social institutions. In fact, PRD officials estimate that roughly 10 to 30 percent of the party operating budget comes from migrants, and 50 percent of campaigns are financed through transnational economic remittance flows (Levitt 2001, 149). Aside from strengthened transitional linkages, residents of Miraflores felt these new ideas generated demands for political alternatives to the status quo, particularly for more transparency and less local-level corruption. For example, one respondent said: 
I have never been to Boston, but my brothers say that the elections there are honest. Bill Clinton can't just tamper with votes because he wants to stay in power like Balaguer does here. In Santo Domingo, politics is a risk. Everything is personal. If I am from one party and you are from another's, we can't share with one another. We can't discuss things. There you can say what you think. During the last elections, my brother told me how Bush and Clinton in a certain TV program said things to each other, and at the end they shook hands and one felt that the things they said remained behind because it was a political thing. Here the same thing happens but after the TV program is over they go outside and fight. (Levitt 2001, 153)

Hearing about political alternatives from migrants prompted new ideas about political relationships at home: “There are greater demands for more democracy within the parties, that the judicial system should be separate from the executive branch which is so corrupt.... Emigration plays a role, since the people who come back come with these new ideas" (Levitt 2001, 153).

Hearing about the activism of Miraflorenos in Boston empowered those at home to reimagine their community's potential. One villager said, "We have begun to imitate US publicity. We use slogans, posters, bumper stickers. We didn't do this before. . . . Also, people are more likely to form groups now. Neighborhood associations, associations of certain kinds of producers and business owners. They learned this in the US, where they felt the need to come together, to work together, to not be so dispersed" (Levitt 2001, 154).

From this perspective, social remittances inspire the exchange of new ideas that trigger increasing reciprocity in the form of economic remittances and also reinforce the village identity and power. However, they can also challenge the basis for transnational village connections and cooperation. When new ideas undermine traditional power dynamics and norms of behavior, for better or worse, they can unravel the links between migrants and villagers. Roughly 35 percent of Miraflores residents feel that migrant ideas have had a negative effect on politics and relations at home. Levitt notes that "several respondents argued that migrants absorbed the worst aspects of American society and then modeled these for their friends and family" (2001, 152). One villager commented:

With respect to the development of a social or cultural consciousness, I see that each day we go from bad to worse. Things are very different than they were fifteen years ago, and I tell you this with a heavy heart. The youth of Miraflores don't think about a future. They are thinking about having fun, getting money to be able to drink beer and go out and dance, and some of them want to go out and get drugs. It is incredible the number of young men who smoke dope. It is the fault of those who live in the US, who go back and encourage their friends to get into this. You know that in Miraflores there is not one house that doesn't have someone living in the US. These kids have never had to work to get their food. They stand around on the corner with their friends. Idleness is the mother of all vice, and since they aren't going to school or work, they fall prey to these vices. (Levitt 2001, 153) 
These concerns echo the warnings and fears of the Amish community described in chapter 3. The spread of new ideas, behaviors, and customs that put the individual above or before the community's needs wreaks havoc on intergenerational relations in receiving communities, as younger folks drift toward new ideas. Certainly digital devices and the internet open up space for transnational interactions between younger generations.

Levitt argues that social remittances are generally transmitted through established sociopolitical or religious institutions, like the PRD, and through faceto-face interactions. Her research does not explicitly address the transmission of social remittances through digital spaces, though she recognizes the power of digital technologies: "New communication and transportation technologies permit easier and more intimate connections. These heighten the immediacy and frequency of migrants' contact with their sending communities and allow them to be directly involved in everyday life there in fundamentally different ways than in the past" (Levitt 2001, 24). Extending her study to Palestinian refugee networks in digital spaces permits exploration of how social remittances create both bridges and divides for transnational reciprocal action.

\section{AFFIRMING AND BUILDING TRANSNATIONAL RECIPROCITY THROUGH A SUBNATIONAL POLITICAL IDENTITY}

Supporting Levitt's assertion that social remittances can strengthen links between migrants and their "home" communities, my own survey data show that social remittances exchanged in digital spaces among Palestinian refugees strengthened transnational connections and encouraged a vibrant reimagination of the community's power. This, in turn, enhanced economic remittance flows.

One survey respondent commented: "The internet builds a bridge among the Palestinian communities, so it's a very good means to connect the Palestinian extended families by narrowing the distance between us, learning about each other's different lives and experiences, but still staying close in the face of differences" (S-20). This trend was especially evident with respect to political ideas exchanged between members of the Samoie village diaspora living in democratically governed countries and villagers still living in the camps. Palestinians using digital networks affirmed their political identity through family and village connections rather than established elite party politics. This is a distinct departure from how most scholarship on Palestinians represents their imagined political identity.

Loren Lybarger traces the downfall of the PLO-Fatah and the shift away from secular political identities in his careful study of Palestinian diaspora communities in Chicago. He notes that among older generations of Palestinian in exile, particularly prior to the 1990s, Palestinian secular identities held great sway. The 
Arab Community Center (ACC), or markaz, founded in 1972, served as a hub for communal activity. Its activities included instruction in the Arabic language, in Arab and Palestinian history and politics, and in activities like tatreez (traditional embroidery) and dabka (village folk dancing) that had become potent symbols of Palestinian identity. According to Lybarger, these activities replicated the way the PLO factions and their associated organizations in the Occupied Territories and in the refugee camps in Jordan and Lebanon raised national awareness and cohesion (Lybarger 2020, 65). However, since that time, there has been a decline in support for secular identities among Palestinians in Chicago, the markaz is no longer the hub of communal activity, and there is an shift toward increasing religiosity.

Recent scholarship discusses how diaspora exile communities have used the Muslim umma (community of faith) to subvert secular political conversations of the past and offer an alternative form of Palestinian political identity. Lybarger (2020) documents the ways in which the umma is being newly deployed to galvanize support for Palestinian justice among the Palestinian community in Chicago. This community has a long history of organizing (Cainkar 2006, 2007), and a multitude of Islamic organizations have emerged from it.

However, Lybarger astutely notes that there is an inherent tension between faith-based organizations and the priorities of Palestinian national liberation and justice. He recounts a conversation with Hatem Abudayyeh, executive director of the Arab American Action Network (AAAN), that explains this tension: "You can't say there's this transnational Islamic experience that we all have. Maybe it helps to organize across nationalities when people look at this concept of umma islamiya [the global Islamic community]. But there are very specific issues based on nationality. There are black issues; Mexican issues; Arab issues, beyond Islam. It liquidates the national question when you organize religiously." National identities and issues mediate religious orientations. Moreover, as Abudayyeh points out, "even if there can be overlap between secular and 'faith- based' organizing frameworks, at key junctures the religious focus contradicts the priorities of national [Palestinian] liberation" (Lybarger 2020, 188-89).

While my refugee respondents certainly emphasized the importance of zakat, or Islamic tithing, in motivating some of their financial decisions to send remittances (I-116L, I-120L), I found less recognition of religious organizations as significant in mediating and organizing political identity among young Palestinians. My survey respondents imagine a political future, shaped by the exchange of social remittances in digital spaces, that explicitly repudiates both secular and Islamist political parties. Palestinian villagers living in camps outside the OT and their transnational networks have generally low expectations and poor opinions of the elite Palestinian establishment embodied by the PLO and Hamas. This was especially evident in the new ideas and conversations exchanged between the members of the diaspora living in democratic countries and those in the camps outside the OT. This evidence of a general shift away from political parties might 
be interpreted as indicating the divisive or factional effects of social remittances in digital spaces. In fact, however, a turn toward discussions of the power and capacity of subnational identity for mitigating problems and solving collective dilemmas has increased transnational village and family communal cohesion, inspired reciprocity, and increased the likelihood of direct cash remittances to those Palestinians suffering most.

One Samoie villager living the United States said in her open-ended survey response: "I would never give money to or support the PLO or Hamas or any of those political parties. They are all corrupt. I feel that most everyone in Nahr al-Bared, unless they are already in the pocket of the party, feels the same way. We just cannot trust any of them. We have to rely on our village network-not a party" (S-43).

Another young Palestinian activist observed: "Listen, my family has historically had deep ties to the PLO. My uncle actually died fighting for them in the 1970s. He is a celebrated martyr. My father is still affiliated with PLO-Fatah, but I do not think many young people like me feel connection to the party in the same way. My community and the way I think about power and activism and reciprocity is not structured by an elite Palestinian political party. It is made up of the relations between myself, my extended family, and broader Samoie village connections. Our power is rooted in those kinship-based connections - not a formal political party!" (I-13oL).

Her father, sitting at the same table and enjoying a coffee with us during the interview, countered: "The PLO is trying to develop intergenerational connections across the camps and the diaspora, especially with the younger kids like my daughter. We have a website and a Facebook group now too!" (I-131L). His daughter retorted, "Babaaaa [Daaaaad], ... no one I know visits that Facebook page. Ha ha ha! We connect through the family and village in digital spaces" (I-130L).

While there is a shared subnational identity that hints at how a state might one day function, the question of that state's relationship to an existing Palestinian political party and to Israel-a one-state or two-state solution (see Lustick 2019 for more discussion on the topic) - is far from resolved among transnational Palestinian villagers.

Divides between those in the diaspora and those in the camps outside the OT and between older and younger Palestinians are evident. The father-daughter conflict over the relevance and structure of a Palestinian state led by elite parties like the PLO illustrates this tension. For example, a college student with family roots in Samoie village said in a survey response: "The older generation has trouble with new ideas about Palestinian identity. But I feel like the younger generation has somewhat integrated many diaspora ideas for the most part. This can be attributed to the use of devices such as phones and computers that keep them connected to other parts of the world on a social, cultural, and political scale. I don't think many young people think of the PLO as revolutionary anymore. We have moved 
onto thinking about Palestinian identity in a new way." The respondent continued: "Within this new generation, they already have incorporated new ideas into the way they think about or do things, whether the rest of the community knows it or not. This is especially obvious to me in how we talk and think about the twostate solution. Spoiler alert: the old ways of thinking about a two-state solution are dead" (S-45).

Though scholars like Ian Lustick (2019) and others no longer believe a twostate solution is viable (perspectives bolstered by Israel's recent move to annex the West Bank), the debate persists among the Palestinian community. Exchanges in digital spaces offer evidence of the tensions over Palestinian identity and state making. For example, though the two-state solution has long been seen as the accepted and acceptable political goal, some young people are entertaining the idea of a one-state solution and viewing the two-state solution as a political pipe dream. One interviewee commented: "Talking to my cousin online, I realized some of us are interested in a one-state solution to the crisis. We both agreed that demographically, Palestinians will represent a majority in that one state, and if the Americans really want democracy in Israel, well, then give them what they want, and let democracy work" (S-48). When asked whether these views are shared by village elders, an interviewee said, "I have no idea. I doubt it. The old people are still all about two states, and they just can't imagine living with Israeli Jews. I want a job, I want a life, I want to be able to travel-I can imagine living next to them, but let us make sure the political process will be a truly democratic one. One state would actually serve my interests more than a two state. I would never speak of this in public with elders, though; this is something I explore privately in my digital networks" (I-126L).

Some third- and fourth-generation Palestinians living in the West are careful to note that while they may share new ideas among themselves, especially with regard to moderation and diplomacy toward Israel, democratic politics, and secularism, they believe real-world village elders will enforce their notions of appropriate political views on the camp community, consistent with the norms of collective loyalty and self-sufficiency. One college-aged Palestinian American with parents who grew up in the camps said in an open-ended survey response:

I was born and raised in the United States, and therefore my lived experience is extremely different from much of my extended family. By being immersed in the US, my education, friends, political views, views on secularism are distinctively American. Where much of my family [over there] would be unwilling to support anything related to Israel, and hold very strong opinions on cooperation and a peaceful solution, I would say that I am much more in the middle, just because I've been exposed to so many people and ideas from immensely different perspectives. ... It is unlikely these ideas of mine would be incorporated because people over there on the ground experience the world differently and would not contest the established norms about Israel outside our community. (S-59) 
For younger people inside and outside the refugee camps, this deviance from older generations' sentiments is hardly surprising. Since the end of the 1993 Oslo Accords, the focus of the Palestinian elite political apparatus has been almost exclusively on people living in the West Bank and Gaza and their relationship to Israel. These young people from Nahr al-Bared and their transnational network have never known a time when elite Palestinian political entities cared about the community left in camps outside the OT. As Walid Khalidi observes, the decision of the PLO to "repudiate exile politics" was viewed as a wise strategy because it helped the party consolidate power (2006, 169-71).

Khalidi notes that this shift alienated Palestinian refugees living in the camps outside the OT and the wider diaspora. Amal Jamal (2005) considers the internal dynamics of the Palestinian political elite and their impact on the struggle to establish a viable Palestinian state in the West Bank and Gaza. Through a series of fascinating interviews, she uncovers how Yassir Arafat and the Fatah leadership sought to mobilize social forces like secular nationalist groups and Islamist movements while at the same time subverting them to shore up PLO-Fatah dominance. Again she shows that the central Palestinian struggle for statehood and community development revolves around elite party politics inside the OT. Palestinians living in camps in Lebanon, Jordan, and Syria and in the wider diaspora have been largely ignored.

Though Laurie Brand extends studies of state formation to the refugee camps and host countries of Lebanon, Jordan, and Syria, she nevertheless views the vibrancy of social and political life through the lens of nationalist party politics. She maintains that the PLO's ability to consolidate power varied in different regions because of the opportunities and constraints of host-country politics $(1988,224)$. Some countries, like Jordan after 1970, were more open to Palestinian integration or actively sought to co-opt refugees. This receptiveness reduced the PLO's power as a key vector for Palestinian identity for refugees living there. In these cases, the host state subsumed the nationalist parties. In Lebanon, by contrast, the PLO was able to exploit the country's sectarian weaknesses and refusal of tawtin to gain political leverage in the camps. Brand integrates Palestinian refugees outside the OT into her discussion of the challenges of state building, but the state-making endeavor still focuses on the actions of Fatah party agents.

Though scholars of Palestinian politics commonly acknowledge that the interests of Palestinians outside the OT have been neglected, there is little consideration of how these refugees might be creating an alternative pathway for community building, one that relies on village networks. New political ideas shared in digital spaces and garnered from diaspora experiences in democratic countries have profoundly shaped Samoie villagers' feelings about their own community's political will and capacity.

Jamal al-Hajj has emerged as an influential person on the Samoie village Facebook page. He grew up in Nahr al-Bared refugee camp, migrated legally, gained 
citizenship in Sweden, and currently lives in the city of Malmö. (In fact, a significant number of people from Samoie village live in Sweden: beginning with an early refugee migrant scout in the 1970s, many have engaged in chain migration through legal sponsorship and endogamous clan marriage.) Since 2014, al-Hajj has been an active member of Sweden's Social Democratic Party. He was recently reelected to another term as a parliamentary representative. In the style of the political circulos de influencia or "influence circles" of family members in the Dominican Republic and the US described by Levitt (2001), al-Hajj frequently posts videos and messages on the Samoie village Facebook page describing the campaign and election process in Sweden, his political platform, and what an honor it is to represent his Palestinian roots in Sweden's democracy.

In August 2018 he posted a video asserting that Sweden is a champion of democracy because it gives individuals a voice regardless of religion and gender. A large number of Samoie villagers living inside the camps and the wider diaspora "liked" the post and engaged in thoughtful conversations in the comment thread congratulating al-Hajj and expressing interest in how a Palestinian voice can be represented in Sweden. He also shared campaign posters and images of him campaigning and attending rallies with Swedes. His Facebook page affirms his transnational audience: he writes his posts in both Swedish and Arabic. He writes about his decision to "fight right-wing populism with equality" in Sweden and promotes ideas about combating climate change and supporting women's rights. Palestinian villagers in the camp demonstrated their pride in his success by reposting images of his recent election win. His activities have inspired younger people in the camp to reimagine their own power and ability to bring about change.

One interviewee commented:

To see a Samoie villager [like al-Hajj] find success and a political platform with democratic support reminds me that no matter what the world says, I am not a terrorist or a bad person incapable of helping myself and my community. It goes to show that someone like me can do good things and be in politics and not be corrupt. Normally you think Palestinian politics, and you think of corruption and sell-outs. But I don't think politics has to be that way for us. I spearheaded a cleanup of the cemetery in Nahr al-Bared and worked with the Islamic Relief Organization to do it. That organization relies on the funding from our own people living all over the world. I then mobilized a lot of young people to do the cleanup of our ancestors' graves, and we used the money transparently to improve our camp conditions to give us dignity in death. You know what?! This sounds like the beginning of Palestinian democracy to me! (I-117L)

Though Levitt (2001) demonstrates how the exchange of social remittances strengthened transnational bonds and led to increasing financial support of Dominican political parties and campaigns, my surveys and interviews show that Palestinian refugees rarely contribute to political parties. This finding deviates from typical conceptions of Palestinian nationalism. Many Palestinians 
outside the OT have no allegiance to Fatah-PLO or Hamas. Lybarger (2020) documents the failures of secular parties to muster broad support among the young generations of diaspora Palestinians in Chicago. In my interviews, one Palestinian living in Dubai said, "The financial support I share only goes to my family and village. The existing Palestinian political parties don't really care about people like my family in the camps in Lebanon" (I-126L). Instead, most members of the Palestinian diaspora were sending money to family and village networks. A member of the Samoie diaspora in the United States commented: "I would never give money to a political party in the refugee camps or in the OT, but seeing young people do good things like cleanups in the camp graveyard and doing civically minded activities documented on Facebook is something I can get behind. It is how a democracy should function, and our people are intuitively oriented toward this because we have always had our loyalty to serve others-our family and village community-above our personal gain. I send money to those kids doing good work in the camps. This is our village democracy at work" (I-114L).

Jamal al-Hajj also posts images of Swedish politicians, like the former representative Marie Granlund speaking out in support of Palestinians' right to self-determination on the anniversary of the Nakba on May 15, 2019. Upon seeing this, one refugee from the camp said in an interview response, "Seeing images of a Swedish politician supporting our cause and believing that we can have a better political future reminds me that we aren't all alone. When Jamal shares these images, it gives me the fuel to push for a better political community among Palestinians-not rooted in the corruption of elite parties but in a new vision of the future" (I-118L).

Among young Palestinians, any sense of a national identity or a moral duty to serve their people is mediated by digital village and family networks. One student at an elite university in America wrote in his survey response:

I really don't give a crap about religious and secular Palestinian parties. They have never done a single thing to change the lives of my family living in Nahr al-Bared. The only impetus for justice is motivated by my global village network. This network motivates the work for justice and sustains justice for the long term. I am not living in the camp today and I am at college right now because of this network. I know that my younger siblings will only make it out if that same network gets activated. For me, the heart of a future Palestine beats in the traditions and actions of the village. (S-47)

Ideas about the Nakba and how it should be represented in digital spaces provide additional examples of the flow and unifying effects of social remittances. Many Palestinian youth living in the diaspora make efforts to connect to their preNakba origins. Some have never lived in Palestine or a refugee camp. Some have only one Palestinian parent. Though they carefully note their "mixed" status, they still feel deeply connected to pre-1948 family and village frameworks. In the Facebook groups Post Colonial Memes for Oriental Minded Teens, which had 20,895 
members as of July 2018, and Halal Memes for Jannah Minded Teens, which had 158,460 members as of July 2018, there are myriad posts by young Palestinians living in North America and Europe that reflect on their pre-Nakba village identity. For example, around the time of annual national Nakba remembrances on May 15, members shared scanned images of their ancestral homes, images of great-grandparents, papers authenticating family members' service in the British mandate government, and family mementos. One poster noted that it was through her grandmother's stories and her grandfather's pictures that she felt connected to her pre-1948 village. She has never been to this village or lived in a refugee camp, but the family and village frameworks represent her boundaries of an imagined home. Again, national identity is mediated through a subnational identity and network.

Palestinians living in North America, Europe, and Australia also post on camp village Facebook pages. Of the Palestinian diaspora members I interviewed, some were born in Palestine prior to the Nakba, some were born in the refugee camps and migrated to the West, and several were born in third countries of resettlement. For most respondents, one or both of their parents were born in Palestine or in Nahr al-Bared or another refugee camp and had migrated to the West for economic opportunity. At home, many spoke Arabic with their parents, though three respondents spoke only English in their homes. One respondent felt her primary language was Spanish because her mother was of Latino descent, and she rarely spoke Arabic with her father (S-28).

One woman noted: "Even though I was born and raised in the US with an American mother, a large part of my cultural identity is Palestinian because I grew up around my father's Palestinian side of the family." Her father's family was originally from Samoie village, but she has family living in Nahr al-Bared and the Zarqa refugee camp in Jordan. She had visited the refugee camps only a handful of times, but she stayed connected to her relatives in the camps primarily through platforms like Facebook, where she learned of family weddings, births, graduations, and deaths. She commented: "Being in the Northeast of the US has made me a little isolated from my family. Seeing what they are up to on Facebook village pages reconnects me to them and can, if only briefly, remove that feeling of isolation. Having internet platforms to learn about people's daily lives in the camps has also helped me empathize with my family in the camps more" (S-26).

One Palestinian who is very active on village, family, and Palestinian social media wrote about how he feels when he engages with others online: "I feel empathetic and more connected to my people, and to all other people who share the common experience of collective or individual suffering as a result of injustice. Whether it's the Palestinians suffering under the Zionist regime, or Egyptians who are living in the diaspora due to the dictatorship, etc. I also feel encouraged to take part in efforts to ease the suffering of those who face such injustices, through volunteering in relief and social justice efforts." He also noted: "I have a master's 
in environmental engineering, and my primary interest is in creating accessible sustainable technologies that could be used in refugee camps. Conversations with my family over there [in the camps] reveal that people are, in fact, hungry to improve their conditions and believe in climate change too" (S-23).

Digital conversations about the injustices experienced in the camps and the OT have inspired real-world political activism among young people living in the diaspora in democratic countries. Social remittances have inspired virtuous circles of activism and transnational village connections. For example, descriptions of injustices "over there" have spurred protests over immigration and asylum policies in the United States. One respondent wrote:

Every year when the anniversary of the Nakba rolls around, I feel really angry, and hearing all these stories of loss and sadness and the trauma of people stuck in the camps day in and day out moves me to do something. I go to protests in Houston, and I am an active organizer in the Houston Palestinian festival. I was just at a protest over the Palestinian refugee student who was initially denied entry into the United States as he was about to enter school at Harvard. That was some salty racist crap to deny a refugee entry when he was already accepted into Harvard. I want our Palestinian voice represented in the American political landscape too. (S-42)

One Samoie villager, who has a daughter who was born and raised in the United States, said:

These young teenagers protest in the United States in support of Palestinian refugee family living in the camps. For the younger generation that has grown up here [in America], protesting is normal and safe, and they still feel a direct line to the trauma of the Nakba. You cannot watch young children imprisoned for throwing a stone or see your grandfather's desecrated grave and not feel emotionally moved. They have melded the best of American democratic values with their ahl and hamula loyalties. We can sustain our global community of refugees if these young people here in America and in Nahr al-Bared continue on like this. (I-120L)

For the transnational Palestinian community, digital spaces spur the flow of social remittances that strengthen connections, generate economic remittances, and affirm a transnational political identity rooted in $a h l$ and hamula identity.

\section{DIGITAL AND REAL-WORLD GATEKEEPER TENSION}

While digital spaces foster a strong sense of identity and community among Palestinians in the camps and the diaspora, these spaces also give rise to new forms of tension and division. My research suggests that the most divisive aspect of digital interactions is not the introduction or presence of new ideas, which will always diffuse into communities by one means or another, but rather the way digital interaction complicates claims to authority. Before ICTs, sheiks and patriarchs were the gatekeepers of Palestinian communal norms, and they controlled 
the spaces in which people interacted. Today, digital spaces are mostly filled with younger generations of Palestinians, who can interact without interference from these real-world gatekeepers. In effect, digital spaces give rise to a new generation of digital gatekeepers whose online interactions can challenge and ignore norms of honor and shame and change the very nature of the community, its views on reciprocity, and enforcement of those codes (Ramo 2016).

The tension between real-world village elders and digital message board managers was evident in an incident that unfolded in Nahr al-Bared during the spring and summer of 2019. A young Palestinian women from Samoie village posted a plea for scholarship assistance to complete her postgraduate studies. Several thousand dollars flowed in from extended family in North America and Eastern Europe, enabling her to fully fund her last year of college.

In response to the outpouring of financial support; the woman engaged in the common digital practice of publicly thanking and "tagging" individual Facebook members who sent remittances on the communal Facebook page. This gesture could be viewed as a tool for enforcing communal expectations by spotlighting the good behavior of reciprocators and provocatively shunning those who did not contribute. However, the cross-currents of the norms of digital spaces and those of the real world created unanticipated tensions when some older reciprocators in the diaspora learned of the public post of gratitude from younger relatives active on Facebook.

First, for many of the older people, the identification of those who sent money (and, by implication, those who did not) was viewed as immodest and brash, an affront to the practice of more subtle forms of social pressure. Second, some felt it was against Muslim humility to thank specific supporters and not others. They saw the decision to give money as a village obligation, connected to the Muslim practice of charity as coming from the heart, not a means of satisfying one's ego with a public shout-out. Third, the woman's decision to thank people by tagging them on Facebook meant that she omitted to acknowledge those who had supported her but were not active on Facebook. This prompted discord when some reciprocators assumed that others had not given money. Though one man living in Washington, DC, gave several thousand dollars, he was not active on Facebook, so he was not tagged or publicly thanked. He recalled:

It was quite embarrassing to learn of the post. It was not appropriate for her to name some people and not all the people. Frankly, I am 75 and not on Facebook, and I don't want to be publicly thanked. I don't get this whole tagging thing anyways. But what happened was that one person who was on Facebook and gave money called me and asked why I hadn't given any, since I was not mentioned in the post. I had to explain that I did give money. But there was lots of questioning, and I felt that people questioned my integrity and honor. I always give without expectation of public thanking, but I definitely don't want to be publicly shamed when I did, in fact, give. It created lots of unwelcome drama and leaves a bad taste in your mouth. 
It makes it harder to want to support the community financially when you get all this drama. (I-122L)

The young woman was unaware that engaging in what was, to her, the normal practice of thanking and tagging people on Facebook might disrupt traditional norms of honor, communal loyalty, and shame. The Facebook page manager never intervened to delete the post because it was considered "normal" online behavior to tag and thank friends and family on Facebook. To resolve the dilemma, the young woman was urged by her father and grandfather to edit her post and place phone calls thanking every single donor.

The example illustrates the broader tensions that technology introduces to networked refugees. Even in the complex example above, digital posts inspired reciprocal actions and economic remittances to fund a young woman's education. Yet in this digital interaction, the very norms and understandings of appropriate and inappropriate cooperation and behavior were tested and challenged. As one interviewee commented, "After an experience like the drama we just had, who would want to give money again in the future?" Indeed, in the long run these digital interactions may introduce enforcement challenges and dramas that upend the very village and family networks necessary for sustaining reciprocity and community survival amid catastrophic conditions.

\section{CONCLUSION}

The power of digital spaces has been creatively harnessed by the Samoie community. They have created a high-context digital space where shame is used to enforce cultural and historically relevant norms of collectivism, loyalty, and honor. Economic remittances are not the only resource exchanged via ICTs. Diaspora community members engage in the circular transfer of social remittances-ideas, behaviors, and values that flow across borders among transnational communities.

Like the members of the transnational village of Miraflores described by Levitt (1998, 2001), transnational Palestinian villages have witnessed increasing social remittance flows between the diaspora and residents of the refugee camps. Digital spaces offer opportunities for Palestinian villagers to engage in new ways with political elites and state systems. The experience of a Samoie villager campaigning and winning elections in a Swedish parliamentary democracy has inspired young Samoie villagers in Nahr al-Bared to imagine forms of transparent, representative, and democratic political engagement that differ greatly from the elite party politics embodied by Fatah-PLO and Hamas. These forms of social remittances draw the community closer to outsiders and establish a transnational collective identity that underscores the importance of reciprocity.

At the same time, engagement with the technology changes the users and drives wedges between different generations of the transnational village through 
the introduction of new communal gatekeepers in digital spaces. Small conflicts between real-world and digital communal gatekeepers increase the potential for upending the very network of reciprocity that has helped the community weather the challenges of a protection gap. In the long run, these digitally generated problems could severely disrupt the norms and networks necessary to fund vital goods and services. Yet despite the tensions that social remittances may cause in digital spaces, it seems that the core Palestinian ahl and hamula identity, with flexible notions of collectivism, honor, loyalty, steadfastness, and shame, may very well adapt to overcome the tensions introduced by new technologies and new flows of social remittances. 


\section{Reciprocal Activism in Digital Spaces}

In the middle of the novel coronavirus pandemic, Dr. Mina $\mathrm{H}$ (a pseudonym), a young doctor living in the Nahr al-Bared refugee camp, sent out a plea on Facebook and WhatsApp to her extended family and village network around the globe for food and medicine. Just as the rest of the world was experiencing shortages of basic goods like flour, toilet paper, and protective gear, Palestinian refugees were facing dire shortages of food and other essential items. Within a few days of her plea, thousands of dollars had poured into the camp to help buy basic goods like food and medicine.

Refugees around the entire world are confronting suffering unlike anything most of us have seen in our lifetime: 68.5 million refugees have lost their homes, their livelihoods, and access to basic goods and services. Yet Dr. Mina's pleas did not go unheeded. The response illustrates the strategy Palestinians have developed for helping the community weather scarcity and catastrophe.

In her memoir Circle of Quiet, Madeleine L'Engle asserts that communities maintain their wholeness and thrive when the gap between our virtuous selves and our daily actions is a narrow one. Building on this idea, Bryan Stevenson asserts in Just Mercy that when there is scarcity, violence, and injustice, "There is no wholeness outside of our reciprocal humanity." (2014, 290). Reciprocity helps us reduce that gap. It gets people to give greatly of themselves even in terrible conditions. Readers of this book can learn a lot from Palestinian refugees about how to survive catastrophe and solve collective problems while remaining united. We can extend Palestinian refugee strategies to our own suffering communities, closing the gap between our virtuous selves and our daily actions by engaging in reciprocal activism.

\section{LESSONS LEARNED FROM PALESTINIAN REFUGEES}

This book has looked in depth at how Palestinian refugees use digital spaces to inspire transnational reciprocal exchanges. Here I consider how communities, 
refugee and otherwise, might replicate these patterns of reciprocity to weather the inevitable storms of uncertainty and scarcity.

The catastrophic conditions that Palestinians face today are not unique. We live in deeply troubled times. There are ever-increasing numbers of refugees, migrants, "informals," and "stateless" people fleeing violent conflict, climate disasters, and catastrophes like the novel coronavirus pandemic in all corners of the globe (De Soto 1989). At the 2019 World Economic Forum in Davos, the climate justice activist Greta Thunberg pleaded with the global community to push for climate change measures, telling the audience, "I want you to act as you would in a crisis. I want you to act as if our house is on fire. Because it is" (Thunberg 2019). Indeed, in recent years millions of people have literally fled their burning houses because of conflict and climate change.

While we wait as political elites and established institutions dither, this book seeks to answer the simple question, How do communities solve collective problems in suboptimal conditions? In other words, when our houses are burning and no state or organization is stepping up to offer protection and services, how does a community help itself? My research shows that reciprocal exchanges are an adaptive and resilient community response to the needs of the impoverished, the marginalized, and the stateless. We can extend the reach of such exchanges into communities with dysfunctional states and unresponsive institutions.

Experimental research on engendering reciprocity-defined as a cooperative interaction marked by the exchange of favors and privileges-suggests that communities can overcome selfish impulses even in times of great scarcity. Key conditions for reciprocity include the enforcement of norms, or shared understandings of expected behavior, via repeated interactions in familiar group settings (Axelrod 1984; Boyd et al. 2003; Fehr and Gächter 2002; West, Griffin, and Gardener 2006). However, this scholarship has not previously been extended to real-world refugee communities and digital spaces of interaction. Examining the digital behavior of Palestinians living in camps in Lebanon and the diaspora has provided new data on the role of reciprocity and ICTs in refugee community building. The representation of precrisis kinship networks in digital spaces has created high-context interactions where norms of honor and loyalty are easily enforced using shame as a form of social control. In effect, Palestinians are using "old" ways of connection and obligation and making them new again in digital spaces.

Palestinians have endured generations of intractable conflict and shifting and ambiguous political economic rule. Kinship networks have been central to the survival of the Palestinian community under these conditions. The community used ahl and hamula networks to resolve dilemmas during the Ottoman and British mandate periods of rule. These networks offered a framework of relationships and trust with easily enforceable norms, enabling the community to raise funds and cooperate to solve collective problems. Even after the social upheaval caused 
by the Nakba in 1948, the community strategically used malleable notions of honor, shame, and loyalty to obtain needed goods and services.

Inside the refugee camps, Palestinian families and villages clustered in familiar groupings. Even as community members were forcibly pushed or voluntarily migrated from the camps in search of economic opportunity, the same kinship networks structured individuals' identity and obligations. Before the internet, communities used analog tools, such as village history books, to develop a "geography of the displaced" through which the camp community could craft and rebuild their family and village connections. Village elders and the authors of these books served as communal gatekeepers who established clear understandings of the behavior and obligations associated with kinship networks. The village history books forged transnational and intergenerational connections, but over time, as the crisis continued, their limitations became evident: the cost of producing them, a tendency toward static understandings of the community, and dwindling readership and participation.

ICTs have provided a dynamic new platform for Palestinians to reimagine their transnational network and the nature of reciprocity in a digital era. Most Palestinian families and villages have their own Facebook pages, WhatsApp groups, and private online chat rooms. By projecting their precrisis kinship networks into digital spaces, refugee communities have formed high-context places where users know one another's lineage, family legacy, and, most important, norms of appropriate behavior.

Palestinians living in the diaspora are encouraged to send economic remittances back to their family and village still stuck in the refugee camps. One motivator is the use of $a y b$, or shame. The managers of Facebook group pages have become digital gatekeepers who enforce community obligations by shaming those who fail to send remittances. In many ways, digital gatekeepers replicate the role of the real-world village elders who have traditionally enforced community behavioral norms. Shame is an exceptionally powerful tool, and while it may motivate altruistic behavior, it can also be used to harm marginalized groups like women and queer communities. Though elite institutions and dominant social narratives uphold rigid patriarchal interpretations of appropriate Palestinian behavior, some family units are pushing against these stiff understandings and embracing more expansive notions of Palestinian identity and social norms.

ICTs serve as a platform for more than just the exchange of economic remittances. The sociological scholarship on migrant, diaspora, and refugee communities reveals that diaspora community members engage in the exchange of social remittances as well-ideas, behaviors, and values that flow between and among transnational communities and "home" (Levitt 1998, 2001). In these digital space, younger generations of Palestinians in the camps and the diaspora can interact without interference from traditional real-world gatekeepers. They share new 
ideas of how they might interact with the world around them and toward each other. Transnational political experiences in democratic spaces provide hope for a reimagined Palestinian political future. But the empowerment of new digital gatekeepers can also challenge the enforcement of communal norms and undermine the established network of reciprocal exchanges.

Certainly, digital spaces will not serve as a magic bullet capable of solving all the community's ills. Life is far from perfect in Nahr al-Bared. Given the ubiquitous lawlessness and endemic scarcity in the camp, we might expect its community to devolve into "nasty, brutish" behavior. Yet the refugee community is able to solve collective problems, such as accessing water, food, medicine, and other goods and services, with no regular police force or official judicial structure. Trust and reciprocity are abundant among refugees and their transnational network. Despite the political, economic, and legal forces that threaten to atomize the community, refugees strategically use digital spaces to inspire reciprocal exchanges and solve problems.

As our houses continue to burn, we can extend the lessons learned from Palestinian kinship networks in digital spaces to more general forms of reciprocal activism in digital spaces .

\section{BLUEPRINT FOR RECIPROCAL ACTIVISM}

Certainly it will not be easy to shift global conditions that deny refugees basic rights and dignities. During my last interview of 2019, a young Palestinian American woman worried, "You see all this awesome person-to-person exchange of help and services in our [Palestinian] village community, but I wonder, can this be scaled up? Can we get people from outside the village to care too?" An acquaintance at a (prepandemic) dinner party commented, "The problem with refugees is just so big, there is nothing someone like me can really do to help. We need a humanitarian organization and world leaders to solve the problems." There are times when the sheer volume of refugees and the catastrophic conditions in which they live may seem overwhelming. Yet this book offers a window into the resilience of marginalized communities in a broken world.

In response to those wondering about the possibility of scaling up individual exchanges, I submit that this book shows the radically transformative power of individual decisions. The trickle of remittances across the globe from a multitude of ordinary people has generated support essential for the refugee community's survival. A young Palestinian boy is now healing from his critical burns and on his way to a "new normal" life; a Palestinian woman graduated as the first woman doctor in her family and is serving sick patients; people who die in Nahr al-Bared can now be buried with dignity. The virtuous circle of people helping other people continues to expand outward in countless small ways. 
The examples in this book show that each of us has the power to transform injustices, especially in places where conflict may be latent. In latent conflict, the suffering and needs of others and potential pathways for remedying them are hidden, usually because there is a low level of awareness of needs and a lack of parity between those suffering and those with control over or access to valuable resources (Curle and Dugan 1982).

We tend to imagine that the peacemakers must be the heads of state, elite political parties, or international agencies. However, at a recent meeting among practitioners and academics at conference titled "Building Sustainable Peace" at the University of Notre Dame's Kroc Institute, presenters reminded us that peace building is not the realm of the elite: it is historically rooted in the actions of everyday people. In particular, Lisa Schirch, director of the Toda Peace Institute, reminded the audience that peace building "is fundamentally a micro-level endeavor" (Schirch 2019). Taking a cue from this insight, my blueprint for justice radically decenters the transformative power for peaceful change away from huge organizational structures and large operating budgets. Certainly, there is a place for UN organizations and large humanitarian institutions, and by offering my strategies I am not condoning the abrogation of state and institutional responsibility for relieving the suffering of refugees and other groups. But all too often we forget that we are connected to one another with or without the conduit of a state or organizational structure. We, that is, you and $I$, can rediscover our common humanity through reciprocal exchanges.

The stories of Palestinian refugees show that each of us has the power to become a reciprocal activist. We have the power to solve problems like access to personal protective equipment (PPE) to those on the front lines during the coronavirus pandemic. Appallingly, there has been a lack of access to PPE not only for frontline medical workers but also among the grocery clerks and gig workers who have been keeping our communities fed during the prolonged waves of the pandemic. Low-paid workers have long suffered from access to basic services and protections. Most of them have established digital networks where they share stories of their suffering and needs. For example, clerks at most Trader Joe's grocery stores have their own Facebook groups and find ways to support one another.

A central insight of theory on mutual-aid societies-organizations that provide benefits or other help to members who are affected by things such as death, sickness, or unemployment, among other crises-is that when individuals in groups, "can support, help, and influence each other in a reciprocal manner, the inherent potential exists to provide group members with a sense of greater personal, interpersonal, and environmental control over their lives to negotiate high risk situations" (Glitterman and Schulman 2005, preface). Mutual-aid societies encourage individuals to engage with others to protect themselves and develop a plan for action to solve problems in challenging circumstances. My blueprint for reciprocal 
activism focuses on how to enter these spaces for mutual aid and transform circumstances using digital technology. The plan begins with each of us gaining the permission of a marginalized community's digital platform moderator and then entering their digital spaces with the explicit intention to listen and learn from them what they need to make a real difference in their daily lives right now.

Adam Curle and Maire Dugan offer a model of how to transform unpeaceful relations into peaceful ones. Unpeaceful relations are those in which either or both parties are damaged, possibly through physical violence but also through economic or psychological harm. Their model of "conflict transformation" applies not only to situations of open conflict, such as war or sectarian violence, but also to latent conflicts.

Many refugee situations fall into the category of latent conflict. Those with privileges and access to resources often see media reports of large numbers of refugees fleeing violent conflict, but less is reported about the long-term warehousing of refugees, the protection gaps they face, and the conditions of their daily lives. Though global attention may focus on the Syrian refugee and undocumented border crossing (UBC) crises today, refugee crises persist in places like Darfur, Sudan, Liberia, Afghanistan, Iraq, Kosovo, and Rwanda, some of them dating back to conflicts in the previous century. (Jacobsen 2005, 1).

Unpeaceful conditions are marked by structural violence, in which an individual's potential is curtailed as a result of socioeconomic forces (Galtung 1969). For example, the inability of refugees to access basic services and protections creates an unpeaceful space. Peaceful spaces, by contrast, are collaborative spaces where individuals, with the help of others, realize their own potential and where there is a high level of awareness and parity between the suffering and those who might help (Curle and Dugan 1982). Awareness refers not only to whether all parties involved know of the suffering but also to the degree to which all parties are aware of its sources and the possibilities for addressing the situation. Parity considers the balance of power between those that are suffering and those who might help.

Lack of awareness is evident in the scant media coverage of what happens to migrants and refugees after their initial exodus. Even refugees who for a time are front-page news find themselves with very little follow-up care from the communities that sensationalized their stories. When the body of Alan Kurdi, a Syrian refugee toddler, washed ashore on a Turkish beach on September 2, 2015, the world wept. He was buried in Kobani, Turkey, next to his mother and brother, who also drowned. The story of how his father, his village, and his neighborhood endured the tragedy is nowhere to be found.

Accordingly, Curle and Dugan suggest that the first step in transforming a latent conflict is to increase awareness, "to begin the processes of informing people about the issues at stake and empowering people to become agents of change" (1982, 21). Given the lack of coverage in popular media outlets, refugee digital networks offer a means of increasing public awareness and closing the parity gap. Awareness can 
increase when activists gain the permission of the gatekeepers to enter these digital spaces with the explicit intention of listening to and learning from those who are actually suffering.

In Pathologies of Power (2003), Paul Farmer sets out three steps by which activists can increase awareness and begin to shift the balance of power: observe, judge, and act. Though he focuses on the issue of human rights in the medical arena, his approach is also applicable to combating other forms of deep structural inequalities. Activists seeking to aid refugees and other marginalized communities can observe the suffering and needs of refugees by reading refugee posts in social media or watching their videos; they can judge what skills or resources they can offer that help meet those needs; and they can act on this new information by sending money through a digital app or offering their services. These actions may be small: sending US \$10, proofreading a résumé for a refugee applying for a job, or offering English-language lessons on a digital video platform. In turn, the recipient of the gift may then repay the gift by helping another in the community to "pay it forward." These everyday actions can help create a wholly interconnected community capable of surviving catastrophe.

In I've Got the Light of Freedom (1995), Charles Payne documents the extreme oppression, violence, and poverty that Black Americans faced in Mississippi in the years preceding the civil rights movement. Structural violence was so normalized that state officials, sheriffs, and local white residents regularly colluded to carry out public ritualized lynchings and mutilations of Black people. The stories of the civil rights activists Ella Baker and Septima Clark are examples of community organizing and activism that increases awareness and parity between those with access to resources and power and those who are suffering (Payne 1995). These extraordinary women partnered with Black communities in the Mississippi Delta to empower local people to teach others what they needed to know and forge pathways to accessing it. Long-term development of capacities within a community and the creation of collaborative alliances among ordinary people are important in transforming unpeaceful conditions. This strategy proved effective in the deep South because it shielded people from the state crackdowns that large-scale demonstrations elicited and empowered people to solve their own problems.

Histories of the civil rights era often focus on the extraordinary leadership of Martin Luther King Jr. and dramatic, large-scale protests. However, community organizing, as practiced by Ella Baker and Septima Clark, demonstrated that ordinary people are capable of extraordinary acts to improve the conditions in which they live, despite facing everyday violence and oppression (Payne 1995). Instead of relying on hierarchical power structures and traditional elite leadership, community organizers focus on people-to people interactions in which people who are suffering share their stories with one another and with outsider activists; then they collaborate in order to meet those needs, with an emphasis on specific local needs, sensitivity to the structure of the local community, and an appreciation of 
its culture. Payne terms this a "developmental style" of community organization that increases the agency and capacity of those affected by the problems, regardless of whether tactical objectives are met.

This strategy for activism shows that ordinary "people have the right and capacity to have some say-so in their own lives" (Payne 1995, 68). Participatory political and educational activities, akin to the digital spaces where refugees create groups and share their stories, help the communities define their own problems. Baker and Clark developed "schools" where community members shared their stories, in writing and aloud. Sharing these stories led them to the collective realization that they had a story to tell that was a contribution to society and that provided lessons on how to solve their own problems. Baker emphasized that "strong people do not need strong leaders, they simply need each other" and that one must "start where the people are" to find solutions to the problem (Payne 1995, 77, 68). Ordinary people today can go to the digital spaces of communities in need and listen to their stories, their problems, and their solutions-and then act.

One might suppose that my blueprint for people-to-people online activism is made with academic naivete, because most of us are not part of the fabric of precrisis kinship networks that make Palestinian digital spaces so effective, and digital spaces are rife with misinformation. However, biological kinship is not essential for access to and participation in kinlike networks (see Stack 1974; Scott 2009; Hajj 2014, 2016). Though core parts of Palestinian refugee identity are based on historical events, anyone can become part of this network, "like family," by participating in networks of reciprocity and engaging in the transnational digital exchanges. Through reciprocal exchange, the social bond is (re-)formed and cemented (Stack 1974).

Moreover, participation in exchanges can be on a small scale, as simple as sending $\$ 10$ to a community in need through Western Union ${ }^{1}$, using a digital platform to amplify the community's voice, or sharing expertise or skills with a member of that community. Certainly, engaging in exchanges of money or other resources with online-only acquaintances poses a degree of risk. However, there is a certain racial and socioeconomic bias in suspecting that a member of a refugee community is lying when asking for money or services, yet willingly handing over credit-card and other personal information when purchasing from an online megastore. ${ }^{2}$ Both transactions involve risk. However, the positive externalities associated with giving $\$ 10$ to a refugee (whether or not they use it to fund their education or a medical procedure) surely outweigh those of buying fast-fashion jeans online.

\section{CONCLUSION}

Palestinian refugees' digital networks provide critical insights into how reciprocity works in difficult conditions. The blueprint for reciprocal activism that I prescribe begins with the understanding that the suffering of others touches us. We are in 
that suffering and a part of it, whether or not we choose to engage with it. If those communities do not thrive, then ultimately none of us can thrive. The appropriate measure of peaceful conditions around the globe is the well-being of those most "broken" among us and our own health, and this is inescapably one measure. We exist in an inescapable, interconnected web of relations and obligations. My hope is that this book inspires others to step into these digital networks to affect realworld change for the good.

To reiterate, the lessons from Palestinians refugees provide simple but powerful steps for reciprocal activism. Here is a list of steps we can take right now to improve the conditions for refugees, and other marginalized communities, following the principles of Curle and Dugan (1982) and Farmer (2003).

1. Hop online and research the digital networks used by refugees and other marginalized communities. A great place to start for Palestinian refugees is the Palestine Remembered website (www.palestineremembered.com), where each village and camp has its own profile page and a link to its Facebook group. There are also digital message boards where one can contact people from the community. Almost every precrisis community has its own web presence. For help finding those communities online, contact the Critical Refugee Studies Collective (https://criticalrefugeestudies.com).

2. Contact the Facebook group or digital platform page manager to ask permission to enter the space in order to learn about individual needs. Even if the page is public, it is still good practice to get the consent of the community.

3. Observe. Spend some time increasing your awareness of the community's problems. Read, watch, listen, and learn from the stories and news that community members post.

4. Judge. Make a moral judgment about the information you have learned. You are not a neutral observer. Your judgment might read something like this: "The suffering of this marginalized community is wrong, and my (in) action is contributing to that suffering." It can feel hard to implicate ourselves in the suffering of others. This begins the process of shifting power imbalances so that we see a direct connection between our own power and those suffering around the world.

5. Act. Make a choice about the best way you can help the community meet their needs in the midst of a protection gap. Perhaps the answer is to give money when need arises, as in a medical emergency. If you do not have much money, perhaps you have a skill (teaching English, editing résumés or helping with school essays, or knitting warm hats and mittens, to name just a few) that you can put to good use. Giving freely to strangers online requires us to "risk trusting" (Stack 1974). Although it may feel unsettling, this is how collaboration begins to pave the way for more peaceful conditions. 
The moment we send money or offer a service to another person, we enmesh ourselves in the social networks of refugees and adopt some of the expectations of loyalty and honor, and the deep feelings of shame associated with denying help to another person.

These individual acts do not absolve elites or institutions of responsibility; they simply mean that you and I are stepping up right now. Institutions and leaders can be held responsible even while we take personal responsibility to help other people: the two are not mutually exclusive.

We can complement and build on the power of existing community refugee networks, listen to their needs and requests, and buoy them with our own resources to close the protection gap. Kinship networks can expand to include others who agree to follow and expand on communal norms of honor, collective reliance, and loyalty and thus become "like family." According to Thomas Henry Huxley (1853), a community has a nucleus of specific ideas of how to behave but no outer boundary: rather, it has an expansive notion of who can be incorporated into that community if they agree to the core sentiment that the community deserves to exist and meet its basic needs. By engaging in these very small reciprocal exchanges, we begin to recognize our collective humanity and to heal the brokenness of the world today. 


\title{
RESEARCH APPENDIX
}

\author{
INTERVIEWEES, LEBANON
}

2004

I-1L: Business owner, tile and concrete block factory, Nahr al-Bared camp, July 4 I-2L: Head officer, financial assistance to businesses, UNRWA, Nahr al-Bared camp, July 5 I-3L: Camp leader, UNRWA, Nahr al-Bared camp, July 5

I-4L: Lawyer, Nahr al-Bared camp, July 8

I-5L: Area officer, Beqaa northern Lebanon region, UNRWA, Tripoli, July 8

I-6L: Business owner, ice cream cones, Nahr al-Bared camp, July 10

I-7L: Business owner, chocolate factory, Nahr al-Bared camp, July 10

I-8L: Business owner, ice cream production and retail, Nahr al-Bared camp, July 10

I-9L: Business owner, ice cream production and retail, Nahr al-Bared camp, July 11

I-10L: Business owner, aluminum, Nahr al-Bared camp, July 11

I-11L: Business owner, iron, Beddawi camp, July 12

I-12L: Business owner, chocolate factory, Beddawi camp, July 12

I-13L: Business owner, tile factory, Beddawi camp, July 12

I-14L: Business owner, tile and cinderblock production, Beddawi camp, July 12

I-15L: Business owner, carpentry and furniture retail, Beddawi camp, July 12

I-16L: Business owner, ice cream production, Beddawi camp, July 12

I-17L: Business owner, chocolate factory, Beddawi camp, July 12

I-18L: Business owner, carpentry and furniture retail, Nahr al-Bared, July 13

I-19L: Business owner, steel production, Nahr al-Bared, July 13

I-2oL: Field leader, National Association for Vocational Training school, Beirut, July 15

I-21L: Chief public information officer, UNRWA, Beirut, July 15

I-22L: Business owner, carpentry, al-Buss camp, July 17

1-23L: Leader/head, Popular Camp Committee, al-Buss camp, July 17

I-24L: Head, Najda Vocational Center, al-Buss camp, July 17 
I-25L: Camp leader, UNRWA, al-Buss camp, July 17

I-26L: Popular Camp Committee leader, Rashidieh camp, July 18

I-27L: Business owner, iron, al-Buss camp, July 19

I-28L: Business owner, iron, Rashidieh camp, July 19

I-29L: Area officer, Tyre region, UNRWA, Tyre, July 19

I-3oL: Leader, Najda microcredit office, Rashidieh camp, July 19

I-31L: Business owner, ice cream production, Rashidieh camp, July 19

I-32L: Business owner, ice cream production, al-Buss camp, July 20

2007

I- 33L: Popular Camp Committee, meeting with entire committee, Nahr al-Bared camp, February 26

I-34L: Committee member, water and electricity expert, Nahr al-Bared camp, February 26

I-35L: Business owner, Carpentry, Nahr al-Bared camp, February 26

I-36L: Business owner, steel, Nahr al-Bared camp, February 26

I-37L: Business owner, aluminum, Nahr al-Bared camp, February 26

I-38L: Business Owner, cinderblock and tile, Beddawi camp, February 27

I-39L: Business owner, cement and cinderblock, Beddawi camp, February 27

I-40L: Business owner, carpentry, Beddawi camp, February 27

I-41L: Business owner, carpentry, Beddawi camp, February 27

I-42L: Business owner, aluminum, Beddawi camp, February 28

I-43L: Business owner, aluminum, Beddawi camp, February 28

I-44L: Business owner, glass, Beddawi camp, February 28

I-45L: Business owner, tile, Nahr al-Bared camp, March 2

I-46L: Business owner, iron, Nahr al-Bared camp, March 2

I-47L: Meeting with a family of eight, Nahr al-Bared camp, March 3

I-48L: Fatah party member and party accountant, Nahr al-Bared camp, March 4

I-49L: Business owner, Aluminum, Nahr al-Bared camp, March 7

I-5oL: Business owner, Plaster and wall decor, Nahr al-Bared camp, March 7

I-51L: Business owner, tile and cinderblock, Nahr al-Bared camp, March 7

I-52L: Business owner, tile, Nahr al-Bared camp, March 7

I-53L: Camp electrician, Nahr al-Bared camp, March 12

I-54L: Lawyer, Nahr al-Bared camp, March 12

I-55L: Popular Camp Committee, meeting with entire committee, Beddawi camp, March 17

2012

I-56L: Retired Fatah official, Nahr al-Bared camp, May 16

I-57L:Nahr al-Bared resident and UNRWA data collector, May 16

I-58L: Interview with five of twenty-three members of camp committee, Beddawi camp,

May 16

I-59L: UNRWA information officer, Beddawi camp, May 16

I-6oL: Business owner, iron and steel, Beddawi camp, May 17

I-61L: Business owner, carpentry, Beddawi camp, May 17

I-62L: Business owner, steel, Beddawi camp, May 17 
I-63L: Construction worker in Nahr al-Bared rebuild, Beddawi camp, May 17

I-64L: Business owner, carpentry and painting, Beddawi camp, May 17

I-65L: Business owner, carpentry, Beddawi camp, May 17

I-66L: Business owner, gas installation and electrician, Beddawi camp, May 17

I-67L: Business owner, tile and marble, Beddawi camp, May 18

I-68L: Family relocated from Nahr al-Bared, Beddawi camp, May 18

I-69L: Former business owner from Nahr al-Bared, Beddawi camp, May 18

I-70L: Family relocated from Nahr al-Bared, Beddawi camp, May 18

I-71L: Medical doctor who worked in Nahr al-Bared, Beddawi camp, May 18

I-72L: Sheikh, Beddawi camp, May 18

I-73L: Family relocated from Nahr al-Bared, Beddawi camp, May, 18

I-74L: Family relocated from Nahr al-Bared, Beddawi camp, May 18

I-75L: Relocated woman from Nahr al-Bared, Beddawi camp, May 18

I-76L: Relocated woman from Nahr al-Bared, Beddawi camp, May 18

I-77L: Relocated woman from Nahr al-Bared, Beddawi camp, May, 18

I-78L: Nahr al-bared family, new Nahr al-Bared camp, May 19

I-79L: Nahr al-Bared sheikh, new Nahr al-Bared camp, May 19

I-8oL: Nahr al-Bared Camp Committee, sixteen of thirty-four members present, new

Nahr al-Bared camp, May 19

I-81L: Business owner, carpentry, new Nahr al-Bared camp, May 19

I-82L: Business owner, electricity, new Nahr al-Bared camp, May 19

I-83L: Business owner, bathroom construction and tiles, new Nahr al-Bared camp, May 19

I-84L: Business owner, iron and steel, new Nahr al-Bared camp, May 20

I-85L: Business owner, iron, new Nahr al-Bared camp, May 20

I-86L: Business owner, recycled construction materials, new Nahr al-Bared camp, May 20

I-87L: Business owner, construction materials (sand, tiles, cement, steel), new Nahr al-Bared camp, May 20

I-88L: Business owner, bottled water production, new Nahr al-Bared camp, May 20

I-89L: UNRWA reconstruction engineer, new Nahr al-Bared camp, May 21

I-9oL:New Nahr al-Bared camp reconstruction officer, UNRWA northern Lebanon field office, May 23

I-91L: Nahr al-Bared historian, Tripoli, Lebanon, May 24

I-92L: UNRWA chief information officer, UNRWA Lebanon field office, Beirut, May 29 I-93L: :^\$Nahr al-Bared reconstruction engineer liaison to Lebanese government, Beirut, Lebanon, May 29

I-94L: Palestinian embassy representative, chief diplomat to the Nahr al-Bared reconstruction project in the Palestinian-Lebanese Dialogue Committee, May 31

I-95L: Head of Beddawi camp, July 6

I-96L: Former Nahr al-Bared resident, Beddawi camp May 31

2017

I-97L: Nahr al-Bared resident from Dar al-Qadi, July

I-98L: Nahr al-Bared resident from Dar al-Qadi, July

I-99L: Nahr al-Bared resident from Samoie, July

I-10oL: Nahr al-Bared resident from El-Khalsa, July 
I-101L: Nahr al-Bared resident from Saa'sa, Safad, July

I-102L: Nahr al-Bared resident from Safad, July

I-103L: Nahr al-Bared resident from Damon, July

I-104L: Nahr al-Bared resident from Samoie, July

I-105L: Nahr al-Bared resident from Samoie, July

I-106L: Nahr al-Bared resident from Samoie and Ghabsieh, July

I-107L: Nahr al-Bared resident from Samoie, July

I-108L: Nahr al-Bared resident from Akbara and Safad, July

I-109L: Nahr al-Bared resident from Damon, July

I- 110L: Nahr al-Bared resident from Safouri and Saa'sa, July

I-111L: Diaspora resident from Samoie, August

I-112L: Diaspora resident from Samoie, August

I-113L: Diaspora resident from Samoie, August

I-114L: Diaspora resident from Samoie, August1-115L: Nahr al-Bared Sheik interview 1, Samoie, July

I-116L: Nahr al-Bared Sheik interview 2, Samoie, August

I-117L: Diaspora resident from Samoie, August

2018

1-118L: Diaspora resident from Samoie, Safad, July

I- 119L: Diaspora resident from Khan al-Younis, July

I-120L: Diaspora resident from Samoie, July

2019

I-121L: Diaspora resident from Samoie, November

I-122L: Diaspora resident from Samoie, December

I-123L; Diaspora resident from Samoie, December

I-124L: Diaspora resident from Samoie, December

I-125L: Diaspora resident from Samoie, December

I-126L: Diaspora resident from Samoie, December

I-127L: Diaspora resident from Samoie, December

I-128L: Diaspora resident from Samoie, December

2020

I-129L: Diaspora resident from Samoie, January

I-130L: Diaspora resident from Samoie, January

I-131L: Diaspora resident from Samoie, January

\section{DIASPORA SURVEYS}

In addition to in-depth interviews in Palestinian refugee camps, I collected written and oral surveys of members of the transnational diaspora from the Nahr al-Bared refugee camp. The diaspora lived in North America, Europe, Australia, and the Middle East-North Africa (MENA) region. Surveys were recorded using digital platforms like FaceTime, Skype, or Google Surveys. By using the existing (metaphorical) Rolodex of diaspora networks shared with me by people I interviewed in the camps, I was able to gain access to 
diaspora communities around the world. I had four research assistants: Dr. Dina al-Haj, Omar el-Hajj, Mohamed Aboujeamu, and Raghad al-Hajj. In total, my research team and I collected eighty-two surveys between 2016 and 2019. Respondents ranged in age from 18 to their late 7os. Roughly two-thirds of respondents self-identified as men and the rest as women. In 2016-17, I conducted a pilot survey with twenty-five members of the diaspora in Europe, North America, and Australia. Eighteen more digital surveys trickled in from my first batch of surveys in 2018. Later in 2019, the last batch of surveys was collected from members of the diaspora in the United States and the Arab Gulf region. Geographic locations below are self-reported.

S-1: Virginia

S-2: Houston, Texas

S-3: Houston, Texas

S-4: Houston, Texas

S-5: Houston, Texas

S-6: Fairfax, Virginia

S-7: Houston, Texas

S-8: Houston, Texas

S-9: Houston, Texas

S-10: Houston, Texas

S-11: Houston, Texas

S-12: Australia

S-13: Australia

S-14: Sweden

S-15: Sweden

S-16: Germany

S-17: Germany

S-18: Virginia

S-19: Houston, Texas

S-20: Houston, Texas

S-21: Vienna, Virginia

S-22: Houston, Texas

S-23: Canada

S-24: Canada

S-25: Canada

S-26: Boston, Massachusetts

S-27: Chicago, Illinois

S-28: Denver, Colorado

S-29: Atlanta, Georgia

S-30: Atlanta, Georgia

S-31: Arab Gulf

S-32: Arab Gulf

S-33: Croatia
2016-2017

\section{8}


S-34: Croatia

S-35: Croatia

S-36: Sweden

S-37: Arab Gulf

S-38: Libya

S-39: Libya

S-40: California

S-41: California

S-42: Houston, Texas

S-43: Virginia

S-44: Austin, Texas

S-45: Charlottesville, Virginia

S-46: Charlottesville, Virginia

S-47: New York City

S-48: Fairfax, Virginia

S-49: Virginia

S-50: Virginia

S-51: Virginia

S-52: Ohio

S-53: America

S-54: Virginia

S-55: Chicago, Illinois

S-56: Cleveland, Ohio

S-57: Charlottesville, Virginia:

S-58: Washington, DC.

S-59: Virginia

S-6o: Arab Gulf

S-61: Arab Gulf

S-62: Arab Gulf

S-63: Arab Gulf

S-64: Arab Gulf

S-65: Arab Gulf

S-66: Arab Gulf

S-67: Arab Gulf

S-68: Arab Gulf

S-69: Arab Gulf

S-70: Arab Gulf

S-71: Arab Gulf

S-72: Arab Gulf

S-73: Arab Gulf

S-74: Arab Gulf

S-75: Arab Gulf

S-76: Arab Gulf

S-77: Arab Gulf 
S-78: Arab Gulf

S-79: Arab Gulf

S-80: Arab Gulf

S-81: Arab Gulf

S-82: Arab Gulf

\section{Survey Questions}

1. Do you self-identify as Palestinian? Why or why not?

2. Where do you currently live?

3. If known to you, what is your family's Palestinian village or region of origin?

4. Do you have family, a Palestinian refugee camp? If yes, which camp(s)?

5. How do you stay connected to your extended Palestinian family and friends living around the world or in the camps? For example, do you use the phone, handwritten letters, email, Facebook, Skype, or WhatsApp? Please identify the main ways you communicate.

6. Do you own a smartphone or a device that connects to the internet (like a tablet or a computer)?

7. Do you use or look at an internet-based platform (Facebook page, webpage, Twitter, etc.) to connect with your extended Palestinian family and friends? If no, then go to $8 \mathrm{a}$.

If yes, then go to $8 \mathrm{~b}$.

8a. If you don't use internet-based platforms to connect with other Palestinians, why not?

8 b. If you do use internet-based platforms, what kind of information do you learn from them- for example, family history, national history, news of deaths, weddings, graduations, or other celebrations? Please specify what you learn.

9. How do you feel when you look at or learn information about Palestinians on an internet-based platform? For example, do you feel more connected to your people, a greater sense of community, or more empathy? Please share any thoughts (positive or negative) on how you feel when you engage online with them.

10. Do you feel inclined to support your Palestinian family or village with money, loans, gifts, or other tangible means of financial assistance? Does this extend to the support of Palestinian political parties too? Why or why not?

11. Do you feel you bring new or different ideas (for example, about Israel, women's rights, the role of Islam at home, democracy, marriage, environmental sustainability, etc.) to your extended Palestinian family/village/community? Why or why not?

12. Do you feel that the extended Palestinian community will/would incorporate your ideas into the way they think about or do things? Why or why not?

13. Is there anything else you would like to share about how you feel the internet helps or hurts your connections to other Palestinians? If you would like to add anything, please share your thoughts here.

Thank you so much for your time. Your responses are important to me, and I appreciate them. 

NOTES

\section{PREFACE}

1. Interviews are anonymously coded with a number and a letter denoting the place of the interview. For example, I-8L denotes the eighth interview collected in Lebanon. A complete list of interview respondents and surveys appears in the research appendix.

\section{CHAPTER 1. COOPERATION AND COMMUNITY BUILDING IN CATASTROPHE}

1. Some scholars refer to the relationship between Palestinians and Israelis as settler colonialism. I avoid this term because I want a wide audience to engage with this book. As a peace and justice studies professor, my aim is to generate dialogue and peace building. In debating the best terminology to use, I sought the counsel of my Baba, Dr. Hatim Hajj, who fled Palestine in 1948 and lived in a refugee camp until he earned a scholarship to the American University of Beirut in 1960. He reminded me of the story of the Muslim ruler Muawiya, who famously said, "I do not apply my sword where my lash suffices, not my lash where my tongue suffices. And even if there be one hair binding me to my fellow men, I do not let it break. When they pull, I loosen my grip, and if they loosen their grip, I pull.' At times, I feel there is barely a hair connecting Palestinians and Israelis, and I do not want to pull when the other side is pulling. I yield to the notion that I may speak the truth about Palestinian suffering and resilient joy without severing the hair. I refuse to let go of the tiniest thread binding the different communities. Here I refer to Israeli occupation of Palestinian territories and cite scholars like Wolfe (2006) and Masalha (2003), but I do not directly engage in the settler-colonial debate to avoid endangering the conversation I want to have about Palestinian refugees with Israelis, policymakers, social justice activists, and students. 
2. Surveys are anonymously coded, with the letter $S$ denoting written and oral responses recorded using digital platforms like FaceTime, Skype, and Google surveys and numbers indicating the sequence of the survey responses. Information about the survey questions appears in the appendix.

3. Interestingly, studies of Palestinian villages from which large numbers of migrants moved to the West prior to 1967 have shown that families living on remittances were perceived by other villagers as adopting Western values and rejecting traditional lifestyles (Lutfiyya 1966: Escribano and elJoubeh 1981).

4. Of course, the majority of these conversations are not really private because the data is stored by the companies that own the platforms and may be monitored by state officials.

5. The multidisciplinary research on cooperation, altruism, and reciprocity is extensive. Scholars in philosophy, religion, economics, political science, psychology, and evolutionary biology have approached the topic from a multitude of perspectives. It seems that the disciplines adopt different terms to mean, essentially, the same thing. It is not my intention to engage in an academic turf war over terms; rather, I focus on identifying a clear definition of the phenomenon for the purposes of this book.

\section{CHAPTER 2. MAPPING PALESTINIAN AHL AND HAMULA NETWORKS IN ANALOG AND DIGITAL SPACES}

1. In the book, Grant says the death occurred in a Muslim family, but, given the names of the bereaved (Peter and Naomi), he may have been describing the mourning of a Palestinian Christian family.

2. See Shlaim 1995 for a concise outline of the different perspectives on the events of 1948 .

3. This migratory journey was immortalized in Ghassan Kanfani's epic novel Men in the Sun (1963).

4. Abu Ra'ed's family gave me explicit permission to share these images for research and publication purposes. Though the content is actually public according to privacy laws, I did not feel it was ethical or appropriate to share images without the explicit permission of the individual's family. This decision has meant using fewer visual examples in the book, because only a handful of people agreed to sharing images. These images are, however, representative of those found on village and family Facebook pages.

5. The absence of posts from locations between two thousand and four thousand miles from Nahr al-Bared arises because these regions consist primarily of ocean.

\section{CHAPTER 3. RECIPROCITY, ENFORCEMENT, AND ECONOMIC REMITTANCES}

1. Sady Doyle (2011) chronicles the dangers of being a feminist blogger, citing her own experiences and those of colleagues. "It's been an open secret," she writes, "that having a visibly female online identity . . . is a personal security risk." In 2016, the Guardian analyzed over seventy million comments on its site and found that eight of the ten writers who received the most abuse were women; the other two were Black men (Gardiner et al. 2016). 


\section{CHAPTER 5. RECIPROCAL ACTIVISM IN DIGITAL SPACES}

1. Admittedly, Western Union is not universally loved, though it is an essential component of refugee life. See Bennet and Etter (2017).

2. The fraud study released by Javelin Strategy \& Research (2018) stated that the number of identity fraud victims increased by 8 percent (rising to 16.7 million US consumers) since 2017, a record high since the company began tracking identity fraud in 2003. The study found that despite industry efforts to prevent identity fraud, fraudsters netted 1.3 million more victims in 2017 , with the amount stolen rising to $\$ 16.8$ billion. 



\section{REFERENCES}

Abu el-Haj, Thea Renda. 2015. Unsettled Belonging: Educating Palestinian American Youth after 9/11. Chicago: University of Chicago Press.

Ahmed, Sara. 2017. Living a Feminist Life. Durham, NC: Duke University Press.

Aleinikoff, T. Alexander, and Leah Zamore. 2019. Arc of Protection. Stanford, CA: Stanford University Press.

Al-Hardan, Anaheed. 2016. Palestinians in Syria: Nakba Memories of Shattered Communities. New York: Columbia University Press.

Alqaisiya, Walaa. 2018. "Decolonial Queering: The Politics of Being Queer in Palestine." Journal of Palestine Studies 47 (3): 29-44.

Alqaisiya, Walaa, Ghaith Hilal, and Haneen Maikey. 2016. "Dismantling the Image of the Palestinian Homosexual: Exploring the Role of alQaws." In Decolonizing Sexualities: Transnational Perspectives, Critical Interventions, ed. Sandeep Bakshi, Suhraiya Jivraj, and Silvia Posocco, 125-40. London: Counterpress.

alQaws. 2014. "Statement Re: Media Response to Israel's Blackmailing of Gay Palestinians." alQaws. 19 September. http://alqaws.org/articles/alQaws-Statement-re-media-response -to-Israels-blackmailing-of-gay-Palestinians?category_id=o.

Amir-Ebrahimi, Masserat. 2008. "Transgression in Narration: The Lives of Iranian Women in Cyberspace." Journal of Middle East Women's Studies 4 (3): 89-115.

Anderson, Benedict. 1983. Imagined Communities. New York: Verso Press.

Andreoni, James, and John Miller. 2002. "Giving according to GARP: An Experimental Test of the Consistency of Preferences for Altruism." Econometrica 70 (2): 737-53.

Angelou, Maya. 1969. I Know Why the Caged Bird Sings. New York: Random House.

Appadurai, Arjun. 1990. "Disjuncture and Difference in the Global Cultural Economy." Theory, Culture, and Society 7: 295-310.

Appadurai, Arjun. 1996. Modernity at Large: Cultural Dimensions of Globalization. Minneapolis: University of Minnesota Press. 
Ashtan, Sa'ed. 2020. Queer Palestine and the Empire of Critique. Stanford, CA: Stanford University Press.

Axelrod, Robert. 1984. The Evolution of Cooperation. New York: Basic Books.

Axelrod, Robert, and William D. Hamilton. 1981. "The Evolution of Cooperation." Science 211 (4489): 1390-96.

Baciagalupe, Gonzalo, and Maria Camara. 2012. "Transnational Families and Social Technologies: Reassessing Immigration Psychology." Journal of Ethnic and Migration Studies 38 (9): 1425-38.

Balch, Emily Greene. 1948. “Toward Human Unity, or beyond Nationalism.” Nobel Peace Prize Lecture. April 7. www.nobelprize.org/prizes/peace/1946/balch/lecture.

Balch, Emily Greene. 1972. "What It Means to Be an American." Address delivered at Wellesley College, February 22, 1916. In Beyond Nationalism: The Social Thought of Emily Greene Balch, ed. Randall Mercedes. New York: Twayne.

Baldensperger, Philippe. 1913. The Immovable East: Studies of People and Customs of Palestine. London: Sir I. Pitman \& Sons.

Balkan, Osman. 2015. "Burial and Belonging." Studies in Ethnicity and Nationalism 1 (15): 120-35.

Barnett, Robert. 2001. " 'Violated Specialness': Western Political Representations of Tibet." In Imagining Tibet: Perceptions, Projections, and Fantasies. Boston: Wisdom.

Basaninyenzi, Uwimana. 2013. "Crossing Borders: Social Remittances and ICTs." World Bank blog. March 26. https://web.worldbank.org/archive/websiteo1603/WEB/201303.

Basch, L., N. Glick Schiller, and C. Szanton Blanc. 1994. Nations Unbound: Transnational Projects, Postcolonial Predicaments, and Deterritorialized Nation-States. Amsterdam: Gordon and Breach.

Bates, Robert. 2001. Prosperity and Violence: The Political Economy of Development. New York: W. W. Norton.

Benitez, José Luis. 2012. "Salvadoran Transnational Families: ICT and Communication Practices in the Network Society." Journal of Ethnic and Migration Studies 38 (9): 1439-49.

Benkler, Yochi. 2006. The Wealth of Networks: How Social Production Transforms Markets and Freedom. New Haven: Yale University Press.

Bennet, Drake, and Lauren Etter. 2017. "Give Us Your Tired, Your Poor, and Your Huddled Masses Yearning to Send Cash.” Bloomberg News. June 16. www.bloomberg.com/news /features/2017-06-16/for-western-union-refugees-and-immigrants-are-the-ultimate -market.

Bowker, Robert. 2003. Palestinian Refugees: Mythology, Identity, and the Search for Peace. Boulder, CO: Lynne Rienner.

Bowman, Glenn. 1993. "Nationalizing the Sacred: Shrines and Shifting Identities in the Israeli-Occupied Territories." Journal of the Royal Anthropological Institute 28 (3): 431-60.

Bowman, Glenn. 2001. "The Two Deaths of Basem Rishmawi: Identity Constructions and Reconstruction in Muslim-Christian Palestinian Community." Identities: Global Studies in Culture and Power 8 (1): 47-81.

Boyd, R., and P. J. Richerson 1989. “The Evolution of Indirect Reciprocity." Social Networks. 11: $213-36$.

Boyd, Robert, Herbert Gintis, Samuel Bowles, and Peter Richerson. 2003. "Evolution of Altruistic Punishment." Proceedings of the National Academy of Sciences 100 (6): 3531-35. Brand, Laurie. 1988. Palestinians in the Arab World: Institution Building and the Search for a State. New York: Columbia University Press. 
Bringa, Tony. 1995. Being Muslim in the Bosnian Way: Identity and Community in a Central Bosnian Village. Princeton, NJ: Princeton University Press.

Brown, Brené. 2007. I Thought It Was Just Me (But It Isn't): Making the Journey from "What Will People Think?" to "I Am Enough.” New York: Penguin.

Brown, Vincent. 2008. The Reaper's Garden: Death and Power in the World of Atlantic Slavery. Cambridge, MA: Harvard University Press.

Bruhns, Fred. 1955. “A Study of Refugee Attitudes.” Middle East Journal 9 (2): 133.

Burton, Isabel. 1875. The Inner Life of Syria, Palestine, and the Holy Land. London: Henry S. King.

Butler, Judith. Gender Trouble: Feminism and the Subversion of Identity. New York: Routledge 1999.

Butters, Andrew Lee. 2008. “The Ruins of Nahr al-Bared." Time blog, March 14. http://time -blog.com/middle_east/2008/03/nahr_albared_was_once_one.html?xid=rss-mideast.

Cainkar, Louise. 1994. "Palestinian Women in American Society: The Interaction of Social Class, Culture and Politics." In The Development of Arab-American Identity, ed. Ernest McCarus, 85-105. Ann Arbor: University of Michigan Press.

Cainkar, Louise. 1999. “The Deteriorating Ethnic Safety Net among Arab Immigrants in Chicago." In Arabs in America: Building a New Future, ed. Michael W. Suleiman. Philadelphia: Temple University Press, 192-206.

Cainkar, Louise. 2006. "Immigrants from the Arab World." In The New Chicago: A Social and Cultural Analysis, ed. John P. Koval, Larry Bennett, Michael Bennett, Fassil Demissie, Roberta Garner, and Kiljoong Kim, 182-96. Philadelphia: Temple University Press.

Campo, Juan Eduardo. 2001. "Burial." in Encyclopaedia of the Qur'an, Volume 1. ed. Jane McAuliffe, 263-65. Boston: Brill.

Chaaban, J., N. Salti, H. Ghattas, A. Irani, T. Ismail, and L. Batlouni. 2016. Survey on the Socioeconomic Status of Palestine Refugees in Lebanon, 2015. American University of Beirut (AUB) and United Nations Relief and Works Agency for Palestine Refugees in the Near East (UNRWA).

Christoff, Stefan. 2004. "Living War: Palestinian Refugees in Lebanon.” Zmag. January 14. www.zmag.org/content/print_article.cfm?itemID=4837\&sectionID=22.

Clarke, Joseph. 2007. Commemorating the Dead in Revolutionary France. Cambridge: Cambridge University Press.

Cooley, John K. 1999. "Lebanon Will Be Throwing Its Own Concerns on the Table." International Herald Tribune. December 21.Crespi, Bernard. 2006. "Cooperation: Close Friends and Common Enemies." Current Biology 16 (11): R414-15.

Curle, Adam. 1971. Making Peace. London: Tavistock.

Curle, Adam, and Maire Dugan. 1982. "Stages and Sequence of Conflict." Peace and Change $8(2-3): 19-28$.

Curzon, George. 1901. Frontiers. Oxford: Clarendon Press.

Dalton, George. 1961. "Economic Theory and Primitive Society." American Anthropologist 63: 1-25.

Danforth, Loving M. And Alexander Tsiaras. 1982. The Death Rituals of Rural Greece. Princeton, NJ: Princeton University Press.

Daniels, Jessie. 2009. "Rethinking Cyberfeminism(s): Race, Gender, and Embodiment." Women's Studies Quarterly 37 (1): 101-24.

Darwish, Mahmoud. 1984. "The Earth is Closing in on Us." In Mahmoud Darwish et al., Victims of a Map, trans. Abdullah al-Ud-hari. London: Al Saqi. 
Davis, Angela. 2016. Freedom is a Constant Struggle: Ferguson, Palestine; Foundations of Movement. Chicago: Haymarket.

Davis, Rochelle. 2010. Palestinian Village Histories: Geographies of the Displaced. Stanford, CA: Stanford University Press.

Davis, Rochelle, and Mimi Kirk. 2013. Palestine and Palestinians in the Twenty-First Century. Bloomington: Indiana University Press.

De Soto, Hernando. 1989. The Other Path: The Invisible Revolution in the Third World. London: I. B. Tauris.

De Stone, Roshan, and David Suber. 2019. “The Failed Reconstruction of Lebanon's Nahr al-Bared Palestinian Camp." New Arab. June 11.

Dodin, Thierry, and Heinz Rather. 2001. "Imagining Tibet: Between Shangri-La and Feudal Oppression.” In Imagining Tibet: Perceptions, Projections, and Fantasies, ed. Thierry Dodin and Heinz Rather, 391-416. Boston: Wisdom.

Dominguez, Virginia. 1989. People as Subject, People as Object: Selfhood and Peoplehood in Contemporary Israel. Madison: University of Wisconsin Press.

Doyle, Sady. 2011. "A Girl's Guide to Staying Safe Online." In These Times, November 17, www.inthesetimes.com/article/12311/the_girls_guide_to_staying_safe_online.

Dugan, Maire. 2004. "Peacemaking Processes: Understanding the Connections." Beyond Intractability. www.beyondintractability.org/bi_affiliated_projects/dealing-with-ic/dugan -minigrant2-Curleupdate.pdf.

Durkheim, Émile. 1912. The Elementary Forms of the Religious Life. London: Allen \& Unwin.

Elster, Jon. 1989. "Social Norms and Economic Theory." Journal of Economic Perspectives 3 (4): 99-117.

Escribano, M., and N. el-Joubeh. 1981. "Migration and Change in a West Bank Village." Journal of Palestine Studies 11 (1): 150-60.

Euben, Roxanne. 2006. Journey to the Other Shore. Princeton, NJ: Princeton University Press.

Fabian, Johannes. 1972. "How Others Die: Reflections on the Anthropology of Death." Social Research 39 (3): 543-67.

Farmer, Paul. 2003. Pathologies of Power: Health, Human Rights, and the New War on the Poor. Berkeley: University of California Press.

Farsoun, Samih, and Christina Zacharia. 1997. Palestine and the Palestinians. New York: Westview.

Fehr, E., and U. Fischbacher. 2004. “Third Party Punishment and Social Norms." Evolutionary Human Behavior 25: 63-87.

Fehr, E., U. Fischbacher, and S. Gächter. 2002. "Strong Reciprocity, Human Cooperation, and the Enforcement of Social Norms." Human Nature 13 (1): 1-25.

Fehr, E. and, S. Gächter. 2002. "Altruistic Punishment in Humans." Nature 415: 137-40.

Fehr, E., and J. Henrich. 2003. "Is Strong Reciprocity a Maladaptation? On the Evolutionary Foundations of Human Altruism." CESifo Working Paper 859, Center for Economic Studies and Ifo Institute, Munich.

Fehr, E, and B. Rockenbach. 2003. "Detrimental Effects of Sanctions on Human Altruism." Nature 422 (6928): 137-40.

Fei, Hsiao-Tung. 1946. Peasant Life in China: A Field Study of Country Life in the Yangtze Valley. New York: Oxford University Press. 
Foster, George. 1963. “The Dyadic Contract in Tzintzuntzan, II: Patron-Client Relationships.” American Anthropologist 65: 1280-94.

Fouron, G. E., and N. Glick Schiller. 2002. "The Generation of Identity: Redefining the Second Generation within a Transnational Social Field." In The Changing Face of Home: The Transnational Lives of the Second Generation, ed. Peggy Levitt and M. C. Waters, 168-210. New York: Russell Sage Foundation.

Galtung, Johan. 1969. "Violence, Peace, and Peace Research." Journal of Peace Research $6(3): 167-91$.

Gardiner, Becky, Mahana Mansfield, Ian Anderson, Josh Holder, Daan Louter, and Monica Ulmanu. 2016. “The Dark Side of Guardian Comments." Guardian. April 12.

Geertz, Clifford. 1973. The Interpretation of Cultures. New York: Basic Books.

Glitterman, Alex, and Lawrence Schulman. 2005. Mutual Aid Groups, Vulnerable Populations, and the Life Cycle. New York: Columbia University Press.

Grant, Elihu. 1921. The People of Palestine: An Encyclopedia of the Peasantry of Palestine, Life, Manners, and Customs of the Village. Philadelphia: J. B. Lippincott.

Groshek, Jacob. 2012. "Forecasting and Observing: A Cross-Methodological Consideration of Internet and Mobile Phone Diffusion in the Egyptian Revolt." International Communication Gazette 74 (8): 750-68.

Gruber, H. 1997. "Creative Altruism, Cooperation, and World Peace." In Eminent Creativity, Everyday Creativity, and Health, ed. M. Runco and R. Richards, 463-79. Greenwich, CT: Ablex.

Gualtieri, Sarah M. 2019. Arab Routes: Pathways to Syrian California. Stanford, CA: Stanford University Press.

Habermas, Jürgen. 1962. The Structural Transformation of the Public Sphere. Translated by Thomas Burger. Oxford: Polity Press.

Hajj, Nadya. 2014. "Institutional Formation in Transitional Settings." Comparative Politics 46: 399-418.

Hajj, Nadya. 2016. Protection amid Chaos: The Creation of Property Rights in Palestinian Refugee Camps. New York: Columbia University Press.

Hajj, Nadya, Patrick J. McEwan, and Rebecca Turkington. 2017. "Women, Information Ecology and Political Protest in the Middle East." Mediterranean Politics 24 (1): 62-83.

Hajjaj, Nasri. 200o. "Qubur al-Filastiniyyin fi Lubnan: Laji'un Ahia’an ... Laji'un Amwatan" (Palestinian grave sites in Lebanon: Living and deceased refugees, parts 1 and 2). $A l$ Quds al-Arabi. 2-3 November.

Halevi, L. 2007. Muhammad's Grave: Death Rites and the Making of Islamic Society. New York: Columbia University Press.

Hamid, Mohsin. 2017. Exit West. New York: Penguin Random House.

Hammad, Suheir. 2004. Poem from the documentary Fourth World War. Directed by Rick Rowley. Produced by Big Noise Media.

Hammer, J. 2005. Palestinians Born in Exile: Diaspora and the Search for a Homeland. Austin: University of Texas Press.

Harris, Marvin. 1971. Culture, Man, and Nature: An Introduction to General Anthropology. New York: Thomas Y. Crowell.

Henrich, Joseph, Robert Boyd, Samuel Bowles, Colin Camerer, Ernst Fehr, Herbert Gintis, Richard McElreath, Michael Alvard, Abigail Barr, and Jean Ensminger. 2005. " Economic 
Man' in Cross-Cultural Perspective: Behavioral Experiments in 15 Small-Scale Societies." Behavioral and Brain Sciences 28: 795-855.

Hertz, Robert. 1960. Death and the Right Hand. Trans. Rodney and Claudia Needham. London: Cohen and West.

Hirschman, Albert O. 1970. Exit, Voice, and Loyalty. Cambridge, MA: Harvard University Press.

Hobsbawm, Eric, and Terence Ranger. 1983. The Invention of Tradition. Cambridge: Cambridge University Press.

Hostetler, John A. 1984. "The Amish and the Law: A Religious Minority and its Legal Encounters." Washington and Lee Law Review 141 (1): 33. https://scholarlycommons.law .wlu.edu/wlulr/vol $41 /$ iss1/4.

Huxley, Thomas Henry. 1853. "The Cell Theory." British and Foreign Medico-chirurgical Review 12: 221-43.

Jacobsen, Karen. 2005. The Economic Life of Refugees. Boulder, CO: Kumarian.

Jamal, Amal. 2005. The Palestinian National Movement: Politics of Contention, 1967-2005. Bloomington: Indiana University Press.

Javelin Strategy \& Research. 2018. "Identity Fraud Hits All Time High with 16.7 Million U.S. Victims in 2017." www.javelinstrategy.com/press-release/identity-fraud-hits-all-time -high-167-million-us-victims-2017-according-new-javelin.

Katz, E., and P. Lazarsfeld. 1955. Personal Influence. New York: Free Press.

Kamp, Kathryn A. 1998. "Social Hierarchy and Burial Treatments: A Comparative Assessment." Cross-Cultural Research 32 (1): 79-115.

Kanafani, Ghassan. 1999. Men in the Sun. Translated by Hilary Kilpatrick. Boulder, CO: Lynne Rienner.

Khalidi, Rashid. 1997. Palestinian Identity: The Construction of Modern National Consciousness. New York: Columbia University Press.

Khalidi, Walid. 2006. All That Remains: The Palestinian Villages Occupied and Depopulated by Israelis in 1948. Washington, DC: Institute for Palestine Studies.

Khalili, Laleh. 2005. "Places of Memory and Mourning: Places of Commemoration in Palestinian Refugee Camps in Lebanon." Comparative Studies of Asia, Africa, and the Middle East 25 (1): 30-45.

Khalili, Laleh. 2007. Heroes and Martyrs of Palestine: The Politics of National Commemoration. New York: Cambridge University Press.

Kissau, Kathrin. 2012. "Structuring Migrants' Political Activities on the Internet: A TwoDimensional Approach." Journal of Ethnic and Migration Studies 38 (9): 1381-1403.

Klein, Iris Jean. 1997. "Palestinian Militancy, Martyrdom, and Nationalist Communities in the West Bank during the Intifada." In Martyrdom and Political Resistance: Essays from Asia and Europe, ed. Joyce Pettigrew, 85-110. Amsterdam: VU University Press.

Klisanin, D. 2011. "Is the Internet Giving Rise to New Forms of Altruism?" Media Psychology Review 3 (1). www.psychologytoday.com/files/attachments/85256/internetaltruism -klisanin.pdf.

Knudsen, Are. 2009. "Widening the Protection Gap: The 'Politics of Citizenship' for Palestinian Refugees in Lebanon, 1948-2008." Journal of Refugee Studies 22 (1): 51-73.

Koser, K., and Nicholas Van Hear. 2003. "Asylum Migration: Implications for Countries of Origin." United Nations University/World Institute for Development Economics Research Discussion Paper DP 2003/20. 
Kraybill, Donald. 1998. Puzzles of Amish Life. New York: Simon \& Schuster.

Kraybill, Donald, and Carl Bowman. 2002. On the Backroad to Heaven: Old Order Hutterites, Mennonites, Amish and Brethren. Baltimore, MD: Johns Hopkins University Press.

Krause, Peter. 2017. Rebel Power: Why National Movements Compete, Fight, and Win. Ithaca, NY: Cornell University Press.

Kuran, Timur. 1991. "Now Out of Never: The Element of Surprise in the East European Revolution of 1989." World Politics 44 (1): 7-48.

LaBelle, Brandon. 2018. Sonic Agency: Sound and Emergent Forms of Resistance. Cambridge, MA: MIT Press.

Lawson, Chappell, and Kenneth F. Greene. 2014. "Making Clientelism Work." Comparative Politics. 47 (1): 61-77.

Lee, Richard B. 1969a."Eating Christmas in the Kalahari." Natural History 78 (10): 221-25.

Lee, Richard B. 1969b. "Kung Bushman Subsistence: An Input-Output Analysis." In Environment and Cultural Behavior: Ecological Studies in Cultural Anthropology, ed. A. P. Vayda, 47-79. New York: Natural History Press.

Lees, G. Robinson. 1905. Village Life in Palestine: A Description of the Religion, Home, Life, Manners, Customs, Characteristics, and Superstitions of the Peasants of the Holy Land with Reference to the Bible. New York: Longmans, Green.

Lévi-Strauss, Claude. 1969 [1949]. The Elementary Structures of Kinship. Boston: Beacon Press.

Levitt, Peggy. 1998. "Social Remittances: Migration Driven Local-Level Forms of Cultural Diffusion." International Migration Review 32 (4): 926-48.

Levitt, Peggy. 2001. The Transnational Villagers. Berkeley: University of California Press.

Levitt, Peggy, and N. Glick Schiller. 2004. "Conceptualizing Simultaneity: A Transnational Social Field Perspective on Society." International Migration Review 38 (3): 1002-39.

Levitt, Peggy, and Deepak Lamba-Nieves. 2010. "Its Not Just about the Economy, Stupid: Social Remittances Revisited." Migration Policy Institute blog. www.migrationpolicy.org /article/its-not-just-about-economy-stupid-social-remittances-revisited.

Levitt, Peggy, and M. C. Waters. 2002. Introduction to The Changing Face of Home: The Transnational Lives of the Second Generation, ed. P. Levitt and M. C. Waters, 1-30. New York: Russell Sage Foundation.

Lustick, Ian. 2019. Paradigm Lost: From Two-State Solution to One-State Reality. Philadelphia: University of Pennsylvania Press.

Lutfiyya, Abdulla. 1966. Baytin. The Hague: Mouton.

Lybarger, Loren. 2013. "Other Worlds to Live In: Palestinians Retrievals of Religion and Tradition under Conditions of Chronic National Collapse." In Palestine and Palestinians in the Twenty-First Century, ed. Mimi Kirk and Rochelle Davis, 158-89. Bloomington: Indiana University Press.

Lybarger, Loren. 2020. Palestinian Chicago. Oakland: University of California Press.

Lynch, Marc. 2011. "After Egypt: The Limits and Promise of Online Challenges to the Authoritarian Arab State." Perspectives on Politics 9 (2): 301-10.

MacMillan, Lizzie. 1902. The Letters of Lizzie MacMillan. New York: n.p.

Maitland, C., ed. 2018. Digital Lifeline: ICTs for Refugees and Displaced Persons. Cambridge, MA: MIT Press.

Maitland, C., and Y. Xu. 2015. "A Social Informatics Analysis of Refugee Mobile Phone Use: A Case Study of Zaatari Syrian Refugee Camp (March 31, 2015)." TPRC 43: 43rd 
Research Conference on Communication, Information and Internet Policy. http://dx.doi .org/10.2139/ssrn.2588300.

Maitland, C., Y. Xu, and B. Tomaszewski,. 2015. "Promoting Participatory Community Building in Refugee Camps with Mapping Technology." ICTD '15: Proceedings of the Seventh International Conference on Information and Communication Technologies and Development, 1-4. https://doi.org/10.1145/2737856.2737883.

Masalha, Nur. 2003. The Politics of Denial: Israel and the Palestinian Refugee Problem. London: Pluto.

Mauss, Marcel. 1954. The Gift: Forms and Functions of Gifts in Archaic Societies. London: Cohen and West.

McKay, Deirdre. 2010. "On the Face of Facebook: Historical Images and Personhood in Filipino Social Networking." History and Anthropology 21 (4): 479-98.

Moss, Dana M. 2016. "The Ties that Bind: Internet Communication Technologies, Networked Authoritarianism, and 'Voice' in the Syrian Diaspora." Globalizations 15 (2): 265-82.

Nadan, Amos. 2006. The Palestinian Peasant Economy under the Mandate. Cambridge, MA: Harvard University Press.

North, Douglass. 1995. "The New Institutional Economics and Third World Development." In The New Institutional Economics and Third World Development, ed. J. Harriss, J. Hunter, and C. M. Lewis, 17-26. New York: Routledge.

North, Douglass, and Robert Paul Thomas. 1973. The Rise of the Western World: A New Economic History. New York: Cambridge University Press.

Nouraie-Simone, Fereshteh. 2005. "Wings of Freedom: Iranian Women, Identity and Cyberspace." In On Shifting Ground: Muslim Women in the Global Era, ed. Fereshteh Nouraie-Simone, 61-79. New York: Feminist Press.

NurMuhammad, Rizwangul, Heather A. Horst, Evangelina Papoutsaki, and Giles Dodson. 2016. "Uyghur Transnational Identity on Facebook: On the Development of a Young Diaspora." Identities 23 (4): 485-99.

Oates, Sarah. 2013. Revolution Stalled: The Political Limits of the Internet in the Post-Soviet Sphere. New York: Oxford University Press.

Oirzabal, Pedro J. 2010. Diasporas in the New Media Age. Las Vegas: University of Nevada Press.

Oirzabal, Pedro J. 2012a. "Migration and Diaspora in the Age of Information and Communication Technologies." Journal of Ethnic and Migration Studies 38 (9): 1333-38.

Oirzabal, Pedro J. 2012b. "Diaspora Vasquez and Online Social Networks: An Analysis of Users of Basque Institutional Diaspora Groups on Facebook." Journal of Ethnic and Migration Studies 38 (9): 1469-85.

Oliner, S. P., and P. M. Oliner. 1988. The Altruistic Personality: Rescuers of Jews in Nazi Europe. New York: Free Press.

Omer, Atalia. 2019. Days of Awe: Reimagining Jewishness in Solidarity with Palestinians. Chicago: University of Chicago Press.

Ong, Aihwa. 1999. Flexible Citizenship: The Cultural Logic of Transnationality. Durham, NC: Duke University Press.

Padgett, John F., and Walter W. Powell. 2012. The Emergence and Organization of Markets. Princeton, NJ: Princeton University Press. 
Palestine Remembered. n.d. Village information pages. www.palestineremembered.com. Payne, Charles. 1995. I've Got the Light of Freedom. Berkeley: University of California Press. Pearlman, Wendy. 2017. We Crossed a Bridge and It Trembled: Voices from Syria. New York: Harper Collins.

Peteet, Julie. 2008. "Imagining the New Middle East." International Journal of Middle East Studies 4 (40): 550-52.

Pierson, Paul. 2004. Politics in Time: History, Institutions, and Social Analysis. Princeton, NJ: Princeton University Press.

Prescott, J. R. V. 1987. Political Frontiers and Boundaries. London: Unwin Hyman.

"Pre-war Fabric of Nahr el Bared." n.d. Archnet. https://s3.us-east-1.amazonaws.com/media .archnet.org/system/publications/contents/9533/original/DTP102016.pdf?1397032857.

Qian, Y. 2003. "How Reform Worked in China." In In Search of Prosperity, ed. Dani Rodrik, 297-333. Princeton, NJ: Princeton University Press.

Ramo, Joshua Cooper. 2016. The Seventh Sense. Boston, MA: Little, Brown.

Rinnawi, Khali. 2012. "'Instant Nationalism' and the 'Cyber Mufti': The Arab Diaspora in Europe and the Transnational Media." Journal of Ethnic and Migration Studies 38 (9): 1451-67.

Robinson, Glenn E. 1997. Building a Palestinian State: The Incomplete Revolution. Bloomington: Indiana University Press.

Roy, Sara. 2001. The Gaza Strip: The Political Economy of De-development. Berkeley: University of California Press.

Rubenberg, C. 1983. The Palestinian Liberation Organization: Its Institutional Infrastructure. Belmont, MA: Institute of Arab Studies.

Sahlins, Marshall D. 1965. "On the Sociology of Primitive Exchange." In The Relevance of Models for Social Anthropology, ed. Michael Bunton. London: Tavistock.

Said, Edward, and Jean Mohr. 1986. After the Last Sky. New York: Columbia University Press. Sayigh, Rosemary. 1979. Palestinians: From Peasants to Revolutionaries. London: Zed Books. Sayigh, Rosemary. 1994. Too Many Enemies: The Palestinian Experience in Lebanon. London: Zed Books.

Sayigh, Rosemary. 1995a. "Palestinians in Lebanon: (Dis)solution of the Refugee Problem." Race and Class 37 (2): 27-42.

Sayigh, Rosemary. 1995b. “Palestinians in Lebanon: Harsh Present, Uncertain Future." Journal of Palestine Studies 25 (1): 37-53.

Sayigh, Yezid. 1997. Armed Struggle and the Search for a State: The Palestinian National Movement, 1949-1993. Oxford: Clarendon Press.

Schiff, Benjamin. 1993. Refugees unto the Third Generation: UN Aid to Palestinians. Syracuse, NY: Syracuse University Press.

Schirch, Lisa. 2019. "Conversations about the State of the Field." Speech given at Building Sustainable Peace Conference, Notre Dame Kroc Institute for Peace, November 7-11. https://kroc.nd.edu/news-events/events/building-sustainable-peace-ideas-evidence -and-strategies/keynote-session-livestreams.

Shlaim, Avi. “The Debate about 1948." International Journal of Middle East Studies 27 (3): 287-302.

Schotten, C. Heike. 2018. "To Exist Is to Resist: Palestine and the Question of Queer Theory." Journal of Palestine Studies 47 (3): 13-28. 
Scott, James C. 1990. Domination and the Arts of Resistance. New Haven, CT: Yale University Press.

Scott, James C. 2009. The Art of Not Being Governed: An Anarchist History of Upland Southeast Asia. New Haven, CT: Yale University Press.

Shelef, Nadav. 2010. Evolving Nationalism: Homeland, Identity, and Religion in Israel, 1925-2005. Ithaca, NY: Cornell University Press.

Shirky, Clay. 2011. "The Political Power of Social Media: Technology, the Public Sphere, and Political Change." Foreign Affairs 90 (1): 28-41.

Shteiwi, Musa. 2003. "Arab Women, the Internet and Public Space." Qantara. August 21. http://en.qantara.de/Arab-Women-the-Internet-and-Public-Space/7336c7405i1p489.

Simanowski, Roberto. 2018. The Death Algorithm and Other Digital Dilemmas. Cambridge, MA: MIT Press.

Singh, Prerna. 2015a. "Subnationalism and Social Development: A Comparative Analysis of Indian States." World Politics 67 (3): 506-62.

Singh, Prerna. 2015b. How Solidarity Works for Welfare: Subnationalism and Social Development in India. Cambridge: Cambridge University Press.

Sirhan, Bassem. 1975. "Palestinian Refugee Camp Life in Lebanon." Journal of Palestine Studies 4 (Winter): 91-107.

Stack, Carol. 1974. All Our Kin: Strategies for Survival in a Black Community. New York: Basic Books.

Stevenson, Bryan. 2014. Just Mercy: A Story of Justice and Redemption. New York: Spiegel \& Grau.

Tait, C. 2002. Death, Burial, and Commemoration in Ireland, 1550-1660. Basingstoke: Palgrave MacMillan UK.

Takkenberg, Lisa. 1998. The Status of Palestinian Refugees in International Law. Oxford: Clarendon Press.

Tawny, R. H. 1932. Land and Labor in China. London: George Allen and Unwin.

Taylor, E. 1999. "The New Economics of Labour Migration and the Role of Remittances in the Migration Process." International Migration 37 (1): 63-88.

Thelen, Kathleen. 1999. "Historical Institutionalism in Comparative Politics." Annual Review of Political Science 2 (June): 369-404.

Thelen, Kathleen. 2004. How Institutions Evolve. Cambridge: Cambridge University Press.

Thelen, Kathleen. 2006. "Institutions and Social Change: The Evolution of Vocational Training in Germany." In Rethinking Political Institutions: The Art of the State, ed. Ian Shapiro, Stephen Skowronek, and Daniel Galvin. New York: New York University Press.

Thelen, Kathleen. 2007. "How Institutions Evolve." April 26. Lecture presented at Emory University, Atlanta, GA.

Thunberg, Greta. 2019. "Our House is on Fire." Speech given at World Economic Forum, Davos, Switzerland. www.fridaysforfuture.org/greta-speeches\#greta_speech_jan25_2019.

Tilly, Charles. 1985. "War Making and State Making as Organized Crime." In Bringing the State Back In, ed. Peter Evans, Dietrich Reuschemeyer, and Theda Skocpol, 169-91. Cambridge: Cambridge University Press.

Tsai, Kellee. 2002. Back Alley Banking. Ithaca, NY: Cornell University Press.

Tumarkin, Nina. 1994. The Living and the Dead: The Rise and Fall of the Cult of World War II in Russia. New York: Basic Books.

Tylor, Edward. 1871. Primitive Cultures. Cambridge: Cambridge University Press. 
UNRWA. 2009a. "Consolidated Registration Instructions." January. www.unrwa.org /resources/strategy-policy/consolidated-eligibility-and-registration-instructions.

UNRWA. 2009b. Relief and Early Recovery Appeal (RERA) for Nahr al-Bared Palestine Refugees, September 2008-December 2009. www.unrwa.org/sites/default/files/201007 133727.pdf.

UNRWA. 2013. Reconstruction and Community Mapping of Nahr al-Bared Refugee Camp. https://s3.us-east-1.amazonaws.com/media.archnet.org/system/publications/contents /9533/original/DTP102016.pdf?1397032857

Verdery, Katherine. 1999. The Political Lives of Dead Bodies. New York: Columbia University Press.

Vickstrom, Erik, and Cris Beauchemin. 2016. "Irregular Status, Territorial Confinement, and Blocked Transnationalism: Legal Constraints on Circulation and Remittances of Senegalese Migrants in France, Italy, and Spain." Comparative Migration Studies 4 (15): $1-29$.

Volk, Lucia. 2010. Memorials and Martyrs in Modern Lebanon. Bloomington: Indiana University Press.

Wagner, Sarah. 2008. To Know Where He Lies: DNA Technology and the Search for Srebrenica's Missing. Berkeley: University of California Press.

Wedekind, Claus, and Victoria A. Braithwaite. 2002. "The Long-Term Benefits of Human Generosity in Indirect Reciprocity." Current Biology 12 (12): 1012-15.

West, S. A., A. S. Griffin, and A. Gardener. 2006. "Social Semantics: Altruism, Cooperation, Mutualism, Strong Reciprocity and Group Selection.” European Society for Evolutionary Biology 20 (2007): 415-32.

Winter, Jay. 1995. Sites of Memory, Sites of Mourning: The Great War in European Cultural History. Cambridge: Cambridge University Press.

Wolfe, Patrick. 2006. "Settler Colonialism and the Elimination of the Native." Journal of Genocide Research 8 (4): 387-409. 



\section{N D E X}

AAAN (Arab American Action Network), 74 Abu el-Haj, Thea, 2, 20, 37

Abu Kishk village, 36-37

Abu Rảed (Samoie villager), 38-41, 4ofig., $104 \mathrm{n} 4(\mathrm{ch} 2)$

Abudayyeh, Hatem, 74

ACC (Arab Community Center), 74 access of goods and services: difficulties facing, 49; mobile networks and internet, 9; by refugees, 2-3, 9

activism: about, 24-25; technology pessimists on, 8-9

adaptive values, $15-19$

'adat wa taqlid (norms and values), 21; broadcasting of, 4; defined, xv; obligations and, 54; replication of, $33,38,48$

Africa, 48, 98

After the Last Sky (Mohr and Said), 5

ahl (family) networks, xiv; about, 23, 26-27; adaptive values of, 15-19; as anchors, 26; burial practices and, 28-31; diaspora communities and, 37; diaspora scouts leaving, 7; digital spaces and, 49, 51; ICTs and, 16-17; identity and, 15-19

ahl and hamula networks: about, 26-27; connecting in digital spaces, 38-46; Nakba (Palestinian Catastrophe), 31-32; pre-Nakba burial practices, 28-31; refugee camp chaos, 32-35; strategies for building community cohesion and meeting needs before 1948, 27-28; village history books, $35-37$

aid agencies: funerary rite expenses and, 50-52; ICTs use by, 10-11; lack of funding from, 24; mapping technologies and, 10; meager support from, 26; protection gap and, 4; remittances and, 2; technology and, 10; use of ICTs, 3

All Our Kin (Stack), 48

Alqaisiya, Walaa, 66

alQaws (queer community group), 67

altruism: defined, 11 ; remittance decay and, 7-8

American University of Beirut-UNRWA survey report, 49

Amir-Ebrahimi, Masserat, 58

Amish communities: about, 23; comparisons to, 48, 58, 6o-61; digital technology and, 49, 56-57; organizational units of communal life, 57

Amman, Jakob, 56

Anabaptists, 56

analog spaces: analog tools, 37, 87; mapping networks in, 23, 37; village making, 38 .

See also village history books

Angelou, Maya, 54

Arab American Action Network (AAAN), 74

Arab Community Center (ACC), 74

Arab population, in Palestine, 5

Arab revolutions, 9 
Arab Routes (Gualtieri), 7

Arab states: communal activities in, 74 ; community scouts in, 34-35; Israel on responsibility of, 1 ; nationalist agendas of, 26; power of shame in digital spaces in, 58 ; protection gap and, 32; refugee relief by, 31; revolutions of 2010/2011, 9. See also Lebanon

Arabs: in Germany, 11; in United States, 7, 73-74

Art of Not Being Governed (Scott), 17

Ashtan, Sa'ed, 67

atomization, 5, 6, 88

awareness, 90

'ayb (shame). See shame ('ayb)

Baker, Ella, 91, 92

Balch, Emily Greene, 4

banks: bank accounts, 12, 48; loans, 35

Banks, Ruby, 56

Baqa'a refugee camp, 55

barriers of time and distance, 3, 4

Basque diaspora, 11

behavior. See norms of behavior

Benkler, Yochi, 101

Bethlehem, 20

Biden, Joseph, 1

Black Americans, 23, 48, 52-56, 91

Boston, 71-72

Bowker, Robert, 15, 33

Bowman, Carl, 58

Brand, Laurie, 77

British mandate, xiv, 15, 26, 27, 28, 55, 80, 86

broadcasting: 'adat wa taqlid (norms and values), 4, 17, 19; of Palestinian burials, 24, 38 ; of replicable narratives and images, 49; traditional social networks online, 54

brokenness: defined, xiv; overcoming of, $\mathrm{xv}, 8,94$ Brown, Brené, 64

"Building Sustainable Peace" conference, 89 burials: broadcasting of, 24, 38; burial practices, 28-31, 50; expenses, 50-52. See also Abu Ra'ed (Samoie villager)

Cainkar, Louise, 14, 64

chat rooms, $4,70,87$

Chicago, 79; interviewees from, 99, 100; Palestinians in, 14, 20, 64, 73-74, 79

Christians: burial practices, 29; Christian families, xiv; post-Nakba, 28; urban refugees, 33

Circle of Quiet (L'Engle), 85

citizens: empowerment of, 8; refugees in contrast to, 9 civil rights: denial of, 6; movement in United

States, 91

Clapp Mission, 31

Clark, Septima, 91, 92

climate change issues, 86

codes of behavior, 17, 55

collaboration, 11, 93

community building: community need in Palestinian refugee camps, 49-50; digital spaces and, $\mathrm{xv}, 3$, 27, 38-46; ICTs and, 4, 8-9; Lebanese government working against, 6; mapping technologies and, 10; networked information economy and, 9; pre-1948 strategies, 27-28, 68; reciprocity's role in, 4; regeneration of communities, 9 ; remittance flows and, 8; strategies for, 27-28; using ICTs for, 9

community scouts: after Nakba, 2; dying off of older generations of, 2; remittances of, 34-35

Convention Relating to the Status of Refugees (1951 Convention), 32

Critical Refugee Studies Collective, 93

Curle, Adam, 90, 93

customs. See 'adat wa taqlid (norms and values) cyberbullying, 58

Damon village, 16, 22, 34, 39, 41, 98

Daniels, Jesse, 58

Dar Hilal family, 36

Dar Shraym family, 36

Davis, Rochelle, 23, 27, 33-34, 35-37

The Death Algorithm and Other Digital

Dilemmas (Simanowski), 8

diaspora (term), 2

diaspora communities: connecting in digital spaces, 8, 38-46; economic remittances of, 50-52; members of, 2, 39; transnational camp connections to, $37-38$

diaspora Palestinians: in Chicago, 73-74; economic remittances, 50-52, 53; ICTs and, 50-52; Palestine's future and, 20; reciprocal exchanges with, 53; remittance decay and, 7-8; surveys of, 98-101

Digital Lifeline (Maitland), 10

digital spaces: connecting in, 38-46, 68; cyberbullying, 58; empowerment and, 18-19; fundraising through, 47; gatekeepers and, $81-84,87-88$; lack of anonymity in, 59; patterning of, 49; real-world tensions with, 81-83; reciprocal activism in, 85-94; reciprocity and, 18 ; state officials control of, 
9; of subnational connection, 4-5. See also Samoie village Facebook group

digital technologies: Amish communities and, 49; brokenness and, 8

dispossession: codification of, 5,31 ; digital spaces and, 59; of Palestinian society, 5-6

divorce, 18, 65-66

Dominican Republic, 70, 71-72, 78

double diaspora, 4

Doyle, Sady, 104n1(ch3)

driverless cars, 8

Dugan, Maire, 90, 93

economic issues: banks, $12,35,48$; denial of economic rights, 6; economic growth, 2; economic isolation, 6; economic remittances, $\mathrm{Xv}, 47-49,50-52$; financial remittances, 24 , 47-48; going abroad for economic opportunities, 5, 7; ICTs and, 50-52; networked information economy, 9, 101. See also remittances

education: broadcasting about students, 24; female education, 65 ; fundraising for, 24, 47; remittances and, 2; UNRWA scholarships, 47 Egypt, xiv, 28-29, 80

elders: authority of, 50; role of, 18, 19; shaming ('ayb) used by, 49, 65-66; Sheikh Jihad, 50-51 Elster, Jon, 43 employment (Lebanon), 7

empowerment: of digital gatekeepers, 24; digital networks and, 18-19; media and, 8; of new generations, 18-19; technology pessimists on, 8-9

enforcement: of norms, $13,64-67,86$; power of shame in digital spaces, $58-63$; reciprocity and, 56; of rights, $1,18,47-49$

enforcers: about, 24; community elders as, 18 ; ICT platform managers as, $18-19$; reciprocity and, 14

exchange of goods: in Flats community, 48, 52, 53, 56. See also gift exchange

Exit West (Hamid), 3

Facebook: about, 9, 10, 11; Abu el-Haj on, 37; communal behavior, 55; Palestinian hamula page, 23; reciprocal activism and, 87, 89, 93; from Samoie village, 23, 38-41, 59-63, 65, 75, $77-8 \mathrm{o}, 104 \mathrm{n} 4$ (ch2); scraping data from, 22; survey question on, 101; tagging, 82-83. See also Samoie village Facebook group

FaceTime, 104n2

fake news consumption, 9 familiarity: norms of behavior and, 13; of social groupings, 4, 24, 28, 38, 86-87; using patterns of, $4,14,15-16,33-34$

family ( $a h l$ ) networks. See ahl (family) networks Fara village, 41

fard kifayya (prescribed religious duty), 29

Farmer, Paul, 91, 93

Farsoun, Samih, 27-28

Fatah, 19, 20, 73, 75, 77, 79, 83

Fatah al-Islam (extremist group), 6

favors, exchange of, 3

fawdah (refugee camp chaos), 16, 32-35

Fehr, Ernst, 14, 56

filial connections, 20

Filipinos, 11

financial remittances, 24, 47-48

Fischbacher, U., 56

food access, xiii, 2

foreigners in Lebanon, 6-7

funding: for basic web connectivity in camps, 10; for collective good, 56-57

fundraising: for funeral expenses, 50-52; for remittance fees, 24

funeral rites: fundraising for, 50-52; Lebanese funerals, 45 ; paying for, 53 ; at refugee camps, 45

Gächter, S., 56

Galilee region, 41

gatekeepers: community elders as, 18 ; of digital spaces, 87-88; ICT platform managers as, 18-19, 24; undercutting of, 19, 21, 69, $81-84$

Gaza, 2, 20, 49, 77

generational issues: histories as resource for future, 36; Palestinian diaspora and, 70 , 73-74, 79; political parties, 76-77; reciprocity and, 60 ; remittances, 54 ; shared values as, 38; stakeholders, 18-19; support for next generation, 24. See also village history books

Geneva Convention, xiii, 1

Germany: Arabs in, 11; diaspora members in, 39, 41, 99

ghettoization, in colonial empires and host countries, 16

gift exchange: about, 12; as adaptive strategy, 23; patterns of, 48, 52-56; reciprocity in, 6o-61 globalization: diaspora and, 2, 7; global apathy, $\mathrm{xv}$; global community responsibility, xiii; global conflicts, 2; global statistics on refugees, xiv; smartphones and, 3 ; transnational belonging and, 2 
Google: Google Maps API, 4; Google Surveys, 98, 104n2; Google Voice, 10

Granlund, Marie, 79

Grant, Elihu, 30-31, 104n1(ch2)

Gualtieri, Sarah, 7, 14

Habermas, Jürgen, 8

Haifa (Palestine), xii, xiv, 28

Hairiri, Rafic, 6

Hajj, Hatim, xiv, 103n1(ch1)

al-Hajj, Jamal, 77-78, 79

Halal Memes for Jannah Minded Teens (Facebook group), 80

Hamas, 19, 20, 21, 66, 74-75, 79, 83

Hamid, Mohsin, 3, 9, 69

Hammad, Suheir, 2

hamula (village) networks: about, xiv, 23; as anchors, 26; burial practices and, 28-31; diaspora communities and, 37; diaspora scouts leaving, 7; digital spaces and, 49, 51; ICTs and, 16-17; identity and, 15-19; power of, 4. See also Samoie village Facebook group hawala (informal money-lending system), 48 health issues, broadcasting of, 24 hegira (perilous journey), 1 homophobia, 66 honor: about norms of, 23, 27, 46; as 'adat wa taqlid (norms and values), xv, 4; negotiated claims and, 17

hope, 2, 33, 34, 67, 88, 93

host states: denial of burial to refugees and migrants, xiii; diaspora members in, 2; funerary rite expenses and, 50-52; legal obligations of, 1; legal statues of, 5; meager support from, 1, 26; protection gap and, 4; remittances and, 2; remittances sent from, 2. See also Arab states

housing: challenges facing refugees, xiii; remittances and, 2; shipping container homes (baraksat), 53

Huxley, Thomas Henry, 94

\section{Know Why the Caged Bird Sings} (Angelou), 54

ICTs (information communication technologies): about, $3-5,8$; access and usage of, 9, 22, 23; ahl and hamula patterns and, 16-17, 38, 49; aid agencies use of, 10-11; community building and, 8-9; death observances and, 38; diaspora economic remittances and, 50-52; digital behavior and data on, 86; effectiveness of, 24; empowerment by, 19, 21, 69; evolution of village and family identity and, 69; gatekeeper tension, 18, 81-83; importance of, 38 ; interaction with, 58-59; limitations of usage, 10; old strategies and, 54; optimists on, 3; patterning of, 23, 24, 27; pessimists on, 3; as platform for Palestinians, 87; proliferation of, 38; refugees and, 9-10; resources exchanged via, 83; role of, 3, 4; social remittances and, 69; tangible benefits, 3 ; undercutting by, 19, 21, 69; usage patterns, 39; use by Nahr al-Bared camp refugees, 14. See also Samoie village Facebook group; technology; specific ICT platforms

identity: of givers, 52; ICTs and transnational, 11; imagined community concept, 15 ; national identity, 4-5, 68, 74, 79, 80; primary identities, 15; Said on, 6; subnational identity, 4, 73-81; transnational Palestinian identity, 4, 24,32 . See also ahl (family) networks; hamula (village) networks

Indian subnational identity, 68

indigenous community: denial of, 5 ; dissolution of, 5 ; Scott on, 17

influence circles (circulos de influencia), 71, 78

information: costs and sharing of, 8; popular sources of, 10

information communication technologies (ICTs). See ICTs (information communication technologies)

inheritance, 18

Internet: decentralization of, 8 ; direct engagement over, 25; Internet data collection, 4; Internet data scraping, 4

interviewees, Lebanon, 4, 95-98, 103n1(preface)

Islam: burial practices, 28, 29, 50; Fatah al-Islam (extremist group), 6; Hamas, 19, 20, 21, 66, 74-75, 79, 83; PLO-Fatah, 19, 20, 73, 75, 77, 79, 83; political parties, 19, 74, 77; religious terms, 62; Sunni Islam, 15, 33; survey question on, 101; tithing (zakat), 63, 74; umma (community of faith), 74 .

See also Muslims

Israel: creation of state of, 5, 31; denial of right of return, 5; independence, 31; Israeli lobbying, 5; Israeli occupation, xiii-xiv, 5; Israeli otherness, 19; Israel/Palestinian conflict, 1; legal strategies, 5, 31; Operation Hiram, 33; policy strategies, 5; power and domination 
by, 5; queer communities and, 66-67; on responsibility for refugees, 1

I've Got the Light of Freedom (Payne), 91

Jahoola village, 16, 34

Jamil, Abu, 20-21

jana'iz (burial rites), 50

Jerusalem, 2, 20, 30, 70

Jewish Palestinians, 28

Jordan: burial practices, 28-29; communal activities in, 74; marginalized Palestinian refugees in, 19, 77; passports in, 6; property rights in refugee camps in, 17; social media networks and, 10; Zaatari refugee camp in, 9, 80 ; Zarqa refugee camp in, 54

Just Mercy (Stevenson), xv, 85

Kafr Thulth village, 36

Kanfani, Ghassan, 104n3(ch2)

Katz, E., 8

Khalidi, Walid, 77

King, Martin Luther, Jr., 91

kinship networks: ICTs replicating, 10, 54; obligations and, 48; organization of, 15-19; in pre-Nakba era, 26 ; reciprocity engagement in, 3

Kraybill, Donald, 58, 61

Kroc Institute, 89

Kurdi, Alan (Syrian refugee toddler), 90

LaBelle, Brandon, 9

Lamba-Nieves, Deepak, 71

Lancaster County (Pennsylvania), 48, 56-57

laws (Lebanon): 1964 law, 6; 1995 law, 6; 2000 law, 6-7

Lazarsfeld, P., 8

Lebanon: burial practices, 28-29; communal activities in, 74; conflicts with Fatah al-Islam, 6; foreigners' rights and responsibilities to live and work in, 6-7; interviewee from, 1-2; Lebanese civil war (1975-1990), 5; Lebanese government, 6; marginalized Palestinian refugees in, 19, 77; medical care access in, 47; Palestinian refugee camps in, 5-8, 33; passports in, 6; property ownership, 6-7, 17; refusal of integration (tawtin) of Palestinians, 1, 6. See also Palestinian refugee camps (Lebanon)

Lees, G. Robinson, 29-30

legal issues: legal codes, 5; legal gray areas, xiv; legal obligations, 1; legal statues, 5
L'Engle, Madeleine, 85

Lévi-Strauss, Claude, 52

Levitt, Peggy, 19, 34, 69, 70-73, 78, 83

Libya, 34, 35, 100

lobbying, 5

loyalty: about norms of, 23, 27, 46; as 'adat wa taqlid (norms and values), xv, 4; communal norm of, 48; diminishing bonds of, 2

LGBTQA+ community, 66

Lustick, Ian, 76

Lybarger, Loren, 14, 20-21, 73-74, 79

Maitland, Carleen, 9, 10

Māori, 12

mapping technologies, 10, 23, 37

marginalization: ICTs and, 10; official

development assistance and, 2; of Palestinian refugees, 5, 19; reimagining identities and, 5; shaming and, 24

markets, 2, 3

marriage, $18,28,37,61,64-65$

Masalha, Nur, 5, 103, 103n1(ch1)

Mauss, Marcel, 12, 60

media: empowerment of citizens and, 8 ; information costs and, 8; public sphere strengthening and, 8

medical care access: online community and, 51-52; remittances and, 2; UNRWA and, 47

Meidung (shunning), 48, 56-57, 60, 61

Men in the Sun (Kanfani), 104n3(ch2)

Miraflores (Dominican Republic), 70, 71-72, 83

mobile internet access, 9

Mohr, Jean, 5

Moss, Dana M., 11

Muslims: burial practices, 28-30, 39, 47; fellahin (farmer) classes in camps, 33; jana'iz (burial rites), 50-52; umma (community of faith), 74 . See also Abu Rảed (Samoie villager); Islam

Nadan, Amos, 27-28, 60

Nahr al-Bared refugee camp: access of goods and services, 49; building of, 6 ; destroying of, 6 ; destruction of, 50; elders of, 68; fundraising for, 24; funerary rite expenses and, 50-52; Israeli Operation Hiram and, 33; kinship networks and, 26; Palestinians from Safad region in, 32; rebuilding of, 50; reciprocity and, 14, 59; village groupings at, 15-16, 41. See also Abu Rảed (Samoie villager)

Nakba (Palestinian Catastrophe): experiencing, 23; generations remembering, $\mathrm{xv}, 79$; 
Palestinians after, 26, 41; refugee crisis after, 31-32

national identity, 4-5, 68, 74, 79, 80

national liberation, 74

nationalism, 19-20, 78-79

nationalist parties, $50-52$

norms of behavior: Amish Ordnung, 57, 58;

defined, 13; ICTs and, 17; as key motivator, 4; patrilineal kinship and, 27; replication of, $13,17,24$; strategic melding with new technologies, 4; using precrisis, $15-19$; in village history books, 37. See also 'adat wa taqlid (norms and values); honor; loyalty; shame ('ayb); steadfastness

Nouraie-Simone, Fereshteh, 58

Oates, Sarah, 9

obedience, 48

obligation: community obligations, 6o; in gift exchange, 12, 54

Occupied Territories (OT): communal activities in, 74; ignoring of refugees outside, 20 ; injustices in, 81; Palestinians outside, 5 , 19-21, 70, 74, 75, 77, 79; party politics inside, 77,79 ; violence in, xiv

Oirzabal, Pedro J., 11

Ordnung (Amish norms), 57, 58

Oslo Accords, 19, 77

Ottoman Empire, 15, 26, 27, 30, 55, 86

Palestine Liberation Organization (PLO), 6, 19, $66,74-75,77$

Palestine Liberation Organization (PLO)-Fatah, $19,20,73,75,77,79,83$

Palestinian Catastrophe (Nakba). See Nakba (Palestinian Catastrophe)

Palestinian nationalism, 19-20, 74-75, 78-79

Palestinian refugee camps: establishment of, 31; information needs and access of, 9; PPGIS and, 10; public goods for, 4

Palestinian refugee camps (Lebanon): about, 5-8; community needs of, 49-50

Palestinian refugee identity: power of, 4 ; UNRWA and, 32

Palestinians: in Chicago, 14, 20, 64, 73-74, 79; as mythical, 5; property ownership restrictions in Lebanon, 6-7; rights and responsibilities to live and work in Lebanon of, 6-7; in United States, 20, 59, 61

parity, 90

Partido Revolucionario Dominicano (PRD), 71,73 passports: in Jordan, 6; in Lebanon, 6

Pathologies of Power (Farmer), 91-92

patrilineal kinship, 18, 24, 27-28; fundraising and, 50, 51; structures of, 55. See also ahl (family) networks; hamula (village) networks

Payne, Charles, 91-92

Peasantry in Palestine (Grant), 30-31

peasants, 16, 21, 27, 29-30

PLO (Palestine Liberation Organization), 6, 19, $66,74-75,77$

PLO-Fatah, 19, 20, 73, 75, 77, 79, 83

political parties, 19, 24, 77; consolidation of power and loyalty by, 20; in Dominican Republic, 71-72; Palestinian national liberation and, 74-75; protection gap and, 4; queer communities and, 66-67; shifting power, 26. See also Palestine Liberation Organization (PLO); PLO-Fatah

Post Colonial Memes for Oriental Minded Teens (Facebook group), 79-80

poverty: patterns of reciprocity and, $52-56$; understanding, 48

power, technology and, 18

PPGIS (public participation geographic information system), 10

precrisis: networks, 4, 11, 15-19; norms, 15-19

pre-Nakba burial practices, $28-31$

property ownership: enforcement of rights, 18 ; impositions against, $6-7$; negotiations of, 17; patterns of, 18

protection gap: creation of, 1,32 ; filling of, 4,19 , 25; loyalty bonds and, 2; widening of, 1, 2 proximate causes of reciprocity, 12-13 public participation geographic information system (PPGIS), 10

public sphere: constraint of, 9 ; media and strengthening of, 8 ; widening of, 8

queer communities, 66-67

Queer Palestine and the Empire of Critique (Ashtan), 67

Ramo, Joshua Cooper, 18

Ranaipiri, Tamati, 12

Rashidieh camp, 59

reciprocal activism: about, 24-25, 85, 92-94; blueprint for, 88-92; lessons learned, 85-88 reciprocity: about, 23-24, 47-49, 68; Amish, 57; in Amish communities, 56-57; community need and, 49-50; defined, xv, 3, 11-12; in digital spaces, 56; enforcers and, 14; generating, 11-15; gift exchange patterns 
and, 52-56; ICTs and, 4, 18-19, 24; as key to rebuilding refugee community, $\mathrm{xv}$; of kin-based groups, 3; motivations for, 3, 4; norms of behavior and, 17-18; patterns of, 52-56; proximate causes of, 12-14; receiving, 12; reciprocal humanity (Stevenson on), xv; reciprocators, $14,18,38,56,60,62,82$; role of in refugee community building, 4 ; shame and, 24; technology and, 18-19; transnational reciprocity, 73-81; understanding of, 48 ; universal causes of, 12

Red Cross, xiv

religious organizations: burial practices and, 28-31, 50; norms of behavior, 57,58 ; Palestinian national liberation and, 74 ; religious terms, 62; remittances and, 2; Sunni Islam, 15

remittance decay: defined, 2 ; overcoming of, 7-8; technology pessimists on, 45

remittance flows: dwindling of, 7; of norms and values motivates, 4 ; refugee community building and, 8 ; from transnational diaspora, 3, 24, 49

remittances: community building and, 19-21; of community scouts, 34-35; effects of, 2 ; ICTs and, 24; as investment capital, 35; transfer of, 52

repayment, 12,24

research methodology: about, 21-23; diaspora surveys, 21, 22, 24, 98-101; interviewees, 22, 23, 95-98, 103n1(preface)

resettlement, 9,10

right of return: 1951 Convention and, 32; denial of, xiv, 1, 5; Resolution 194(III) of 1948 and, 1

Roy, Sarah, 15

Russia, 9

Saa'sa village, $16,34,41$

Sabra massacre, 5

Safad region, 32, 34, 41. See also specific villages

Safouri village, 16, 22, 34, 41

Sahyoun, Anthony, xiv-xv, 28-29, 33

Said, Edward, 5

Salah el-Haj, Mayssareh (AKA Abu Ra'ed). See Abu Ra'ed (Samoie villager)

Salama village, 36

salat al jana'iz (funeral prayer), 29

Salt Hospital, xiv

Salvadorans, 11

Samoie (Palestine), xiv, 32-33, 34; Sheik Jihad, $50-51$
Samoie village Facebook group, 59-63, 65, 75, 77-8o, 104n4(ch2); about, 23, 38; on Abu Ra'ed funeral rites, 38-41; 'adat wa taqlid and, 38; ahl and hamula engagement with, 38-39; creation of, 43; fundraising by, 24, 47,51 ; funerary rite expenses and, 50; group member locations, 43-45; ICT usage patterns and, 39; interacting on, 59, 60; postings of, 43-45; research focus on, 23; Sheik Jihad's death, 51

Saudi Arabia, 6o

Sayigh, Yezid, 15, 16

Schirch, Lisa, 89

Schotten, Heike, 66

Scott, James C., 17

scouts. See community scouts

Selenium WebDriver, 4, 22

selflessness, 48

separateness, 56-57

The Seventh Sense (Ramo), 18

shaanta (suitcase) method, 47-48

shame ('ayb): about norms of, 17, 23, 24, 27, 46; as 'adat wa taqlid (norms and values), $\mathrm{xv}, 4$; comparison to Amish Meidung (shunning), $48,56-57,58,61$; dark side of, 24; power of shame in digital spaces, 58-63, 87; queer communities and, 66; shirkers and, 48, 61; as tool, 48, 49

Shatila massacre, 5

Shaykh Hasan site, 36

Sheikh Jihad, 50-51, 68

shirkers: about, 24; shame ('ayb) and, 48, 61

Shteiwi, Musa, 58

shunning: about, 23, 24; in Amish communities, $48,56-57$

Simanowski, Roberto, 8

Singh, Prerna, 21, 68

Skype, 22, 37, 98, 101, 104n2

slacktivists, 9, 45

smartphones: in camps, 69; Hamid on importance of, 3 ; information consumption and, 8; survey question on, 101; uses of, 25

smombies (smartphone zombies), 8, 9, 45

social media networks: parallel universe of, 8 ; reasons for use of, 9-10. See also mapping technologies; specific platforms

social media platforms, most used, 10 social norms, disrupt of, 5

social organization: ahl patterns of, 16-17, 33-34; hamula patterns of, 16-17, 33-34; ICTs and, 4, 16-17, 24. See also ahl (family) networks; hamula (village) networks 
social remittances: defined, 19; flow of, 24 ;

Levitt on, 69; remittance decay and, xv, 7-8; transnational Palestinian identity and, $83-84$; understanding, 71-73

solidarity, in digital spaces, $45-46$

Sonic Agency (LaBelle), 9

stability, in refugee camps, 53-54

Stack, Carol, 23, 48-49, 52-53, 56

state building: marginalization of Palestinian refugees and, 19-21, 26; refugee camps and, 77

state officials, fake news production by, 9 steadfastness: about norms of, 17, 23, 46; as 'adat wa taqlid (norms and values), $\mathrm{xv}, 4$

Stevenson, Bryan, xv, 85 subnational identity: connection through, 4; digital spaces and, 5; in India, 21, 68 ; reciprocity strategies and, 19-21; transnational reciprocity and, $73-81$

suitcase (shaanta) method, 47-48

Sunni Islam, 15, 33

surveys, diaspora members, 4, 101

Sweden, 78

Syria: marginalized Palestinian refugees in, 19, 77; property rights in refugee camps in, 17; UNRWA demands for, 49; wire transfers to, 48

Syrians: in California, 7, 14; global focus on refugees from, 90; social media networks and, 10, 11; Syrian diaspora, 11; in Za'atari refugee camp (Jordan), 9

tagging, 82,83

Takkenberg, 32

tawtin (integration): Lebanon's refusal of, 1; PLO's opposition to, 6

technology: globalization and, 7; power and domination by, 18 ; rebuilding refugee communities and, 4; as a tool, 4; Wi-Fi hubs, 10. See also ICTs (information communication technologies)

technology optimists, 9

technology pessimists, 8-9, 45

Thelen, Kathleen, 43

Thunberg, Greta, 86

Tibet, 20

tithing (zakat), 63, 74

Toda Peace Institute, 89

top-down programs, 11

traditions. See 'adat wa taqlid (norms and values) transnational diaspora: fundraising campaigns, 47; networks, $\mathrm{xv}$, 4; refugees connection with, 4; sparking remittance flows from, 3 ; subnational political identity and, $73-81$; transnational Palestinian identity, 4, 83-84; transnational social fields, 7

Transnational Villagers (Levitt), 71

Trump, Donald, 1

Twitter, 9

Uighurs, 11

umma (community of faith), 74

UN Clapp Mission, 31

UN General Assembly Resolution 194 (III) of 1948,1

UN High Commissioner for Refugees, 32

UN Relief and Works Agency (UNRWA). See UNRWA (UN Relief and Works Agency)

UN Resolution 194(III) of 1948, 1

UN Resolution 302, 31-32

UN Resolution 319, 32

UNHCR (UN High Commissioner for Refugees), 32

United Nations (UN), 10, 31

United States: Boston, 71-72; judicial system, $\mathrm{xv}$; Miraflorenos in, 70, 71-72; Palestinians in, 20, 59, 61. See also Chicago

universal causes of reciprocity, 12

UNRWA (UN Relief and Works Agency), xiv; creation of, 31-32; documentation by, 34; dwindling of aid for, 1; provisions of, 16; rebuilding of Nahr al-Bared, 6; on refugee status, 32; services of, 32; unreliability of, 35; US withdrawal of funding, 1

Unsettled Belonging (Abu el-Haj), 2

urban refugees, 9, 33

values, 4, 56-57. See also 'adat wa taqlid (norms and values); village history books

Viber, 9, 10, 38

village (hamula) networks. See hamula (village) networks

village history books, 23, 27, 35-37, 38, 45, 87

Village Life in Palestine (Lees), 29-30

villages, recreation of in camps, 33-34

Volk, Lucia, 45

warehousing, of Palestinian refugees, 5

welfare services, 2

West Bank, 2, 20, 76, 77

Western Union, 48, 63, 92, 104n1(ch3), 105n1 
WhatsApp: chat groups with, 15 ; fundraising and, 47, 51; Jordan and Syria, 10; private conversations on, 9; reciprocal activism and, 85,87 ; sharing news on, 38,39 ; for survey, 22; survey question on, 101; uses of, 61,66

wire transfers, 48, 6o, 63, 92, 105n1

Wolfe, Patrick, 5, 103, 103n1(ch1)

World Economic Forum, 86
Xu, Ying, 9, 10

YouTube, 10

Zảatari refugee camp (Jordan), 9, 10 Zacharia, Christina, 27-28 zakat (tithing), 63, 74

Zarqa refugee camp (Jordan), 54

Zomia indigenous groups, 17 
Founded in 1893 ,

UNIVERSITY OF CALIFORNIA PRESS

publishes bold, progressive books and journals

on topics in the arts, humanities, social sciences, and natural sciences-with a focus on social justice issues-that inspire thought and action among readers worldwide.

The UC PRESS FOUNDATION

raises funds to uphold the press's vital role as an independent, nonprofit publisher, and receives philanthropic support from a wide range of individuals and institutions-and from committed readers like you. To learn more, visit ucpress.edu/supportus. 
Almost 68.5 million refugees in the world today live in a protection gap, the chasm between protections stipulated in the Geneva Convention and the abrogation of those responsibilities by aid agencies. With dwindling humanitarian aid, how do refugee communities solve collective dilemmas?

In Networked Refugees, Nadya Hajj finds that Palestinian refugees utilize information communication technology platforms to motivate reciprocity-a cooperative action marked by the mutual exchange of favors and servicesand informally seek aid and connection with their transnational diaspora community. Based on surveys conducted with Palestinians throughout the diaspora, interviews with those inside the Nahr al-Bared refugee camp in Lebanon, and data pulled from online community spaces, these findings push back against the cynical idea that online organizing is fruitless, emphasizing instead the productivity of these digital networks.

"With nuance, sensitivity, and fascinating connections across diverse social settings, Nadya Hajj offers a blueprint for how transnational networks can motivate reciprocity to solve communal problems." WENDY PEARLMAN, author of Violence, Nonviolence, and the Palestinian National Movement

"In this remarkable book, Hajj deploys her considerable theoretical and empirical gifts. This book is essential reading for anyone interested in understanding refugee experience." TAREK MASOUD, coauthor of The Arab Spring: Pathways of Repression and Reform

"Through stunning ethnographic and survey research, Hajj provides enormous insights into the way Palestinian refugees in Lebanon and the diaspora not only resist the destruction of their community but have found new ways of rebuilding it, challenging us to think differently about Palestinian refugees and their reimagined futures." SARA ROY, Harvard University

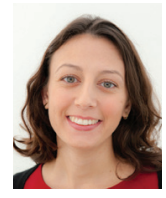

NADYA HAJJ is Whitehead Associate Professor of Critical Thought and Associate Professor of Peace and Justice Studies at Wellesley College.

CRITICAL REFUGEE STUDIES, 2

UNIVERSITY OF CALIFORNIA PRESS

WWW.UCPRESS.EDU

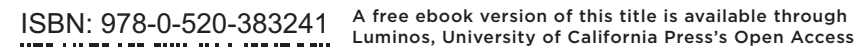
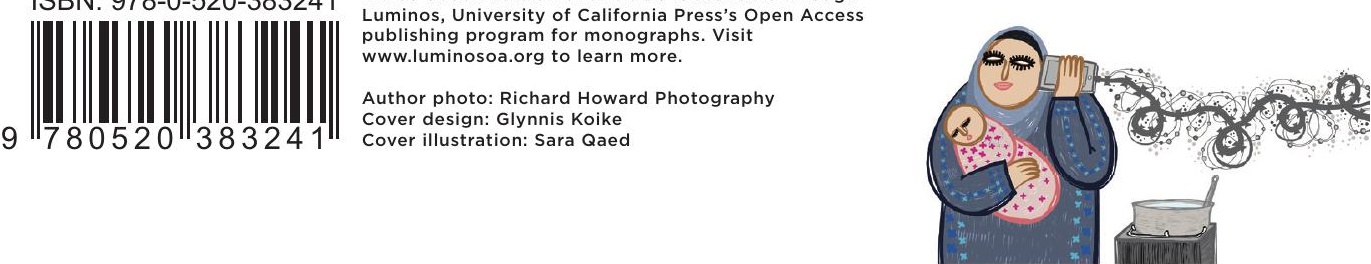